UNIVERSIDADE DE SÃO PAULO

INSTITUTO DE PSICOLOGIA

JOSEILDE MARIA TELES

O VALOR DE APRENDER INGLÊS:

CONSTRUÇÃO DE VALORES POR ADULTOS ESTUDANTES DE

LÍNGUA INGLESA SOB A ÓTICA PIAGETIANA 
Joseilde Maria Teles

\title{
O VALOR DE APRENDER INGLÊS: \\ CONSTRUÇÃO DE VALORES POR ADULTOS ESTUDANTES DE LÍNGUA INGLESA SOB A ÓTICA PIAGETIANA
}

\author{
Versão Corrigida
}

Dissertação apresentada ao Instituto de Psicologia da Universidade de São Paulo como requisito para a obtenção do título de Mestre em Psicologia.

Área de Concentração: Psicologia Escolar e do Desenvolvimento Humano.

Orientadora: Professora Associada Maria Thereza Costa Coelho de Souza. 
AUTORIZO A REPRODUÇÃO E DIVULGAÇÃO TOTAL OU PARCIAL DESSE TRABALHO, POR QUALQUER MEIO CONVENCIONAL OU ELETRÔNICO, PARA FINS DE ESTUDO E PESQUISA, DESDE QUE CITADA A FONTE.

Catalogação na publicação

Biblioteca Dante Moreira Leite

Instituto de Psicologia da Universidade de São Paulo

Teles, Joseilde Maria.

O valor de aprender inglês: construção de valores por adultos estudantes de língua inglesa sob a ótica piagetiana / Joseilde Maria Teles; orientadora Maria Thereza Costa Coelho de Souza. -- São Paulo, 2014.

$157 \mathrm{f}$.

Dissertação (Mestrado - Programa de Pós-Graduação em Psicologia. Área de Concentração: Psicologia Escolar e do Desenvolvimento Humano) - Instituto de Psicologia da Universidade de São Paulo.

1. Piaget, Jean, 1896-1980 2. Língua inglesa 3. Construção de valores 4. Afetividade I. Título. 


\section{FOLHA DE APROVAÇÃO}

Nome: Teles, Joseilde Maria

Título: O valor de aprender inglês: construção de valores por adultos estudantes de língua inglesa sob a ótica piagetiana

Dissertação apresentada ao Instituto de Psicologia da Universidade de São Paulo para obtenção do título de Mestre em Psicologia

Aprovado em:

Banca Examinadora

Prof. Dr.

Instituição

Assinatura

Prof. Dr.

Instituição

Assinatura

Prof. Dr.

Instituição

Assinatura 


\section{DEDICATÓRIA}

À minha mãe, D. Zefa, meu maior exemplo de construção de vida e de amor. 


\section{AGRADECIMENTOS}

Em primeiro lugar, a Deus.

À minha estimada orientadora, professora Maria Thereza, que me acolheu com dedicação e profissionalismo, ao lado de quem me senti completamente segura e amparada durante todo esse percurso de construções.

Às professoras Maria Isabel Leme e Elizabeth Harkot-de-La-Taille, pelas preciosas contribuições ao meu exame de qualificação.

À professora Fraulein, pela amizade e pelos valiosos conselhos.

A todos os professores que fizeram parte desse processo e, de alguma forma, contribuíram para meu crescimento pessoal e profissional.

A todos os professores de inglês, meus colegas de trabalho, em especial ao meu coordenador Charles, cujo apoio e compreensão foram fundamentais para o desenvolvimento desse projeto.

Às queridas colegas de orientação, em especial à Mariana Garbarino, com quem troquei muitas ideias e experiências.

Aos funcionários do Instituto de Psicologia, sempre prontos a ajudar e dirimir nossas dúvidas.

A Roberto, meu fiel aliado, pronto a me ajudar em qualquer circunstância e a me encorajar nos momentos difíceis.

Aos meus amigos, em especial a Luciana Almeida, sempre um raio de alegria e alento em tempos de incerteza.

Aos meus familiares, em especial Lucineia, Tude e meu pai, Givaldo.

E a todos que acreditaram em mim. 


\section{EPÍGRAFE}

Your beliefs become your thoughts,

Your thoughts become your words,

Your words become your actions,

Your actions become your habits,

Your habits become your values,

Your values become your destiny.

(Mahatma Gandhi) 


\section{RESUMO}

O objetivo da presente pesquisa é investigar as relações entre construção de valores e aprendizagem de língua inglesa. Nossa sociedade nos faz crer que é muito importante aprender e falar fluentemente uma língua estrangeira, especialmente a língua inglesa. Aprender uma língua é altamente benéfico em termos acadêmicos, profissionais, pessoais e cognitivos, na medida em que potencializa, por exemplo, a percepção cultural e as habilidades linguísticas de uma pessoa. Porém, os interesses dos estudantes parecem ser majoritariamente influenciados por motivações extrínsecas, já que muitos deles acreditam que é importante aprender inglês para competir no mercado de trabalho. Não sendo necessariamente ruim, o impacto dessa perspectiva deveria ser discutida em termos de como os estudantes coordenam aprendizado de língua estrangeira, interesses pessoais e, consequentemente, valores. Sabe-se que motivações mais extrínsecas tendem a buscar recompensas externas e resultados rápidos, enquanto o aprendizado de uma língua é uma construção pessoal, reflexiva e complexa. Piaget (1954) demonstrou que o interesse é o combustível para a construção do conhecimento. Sem interesse, o aprendiz não se esforça para resolver uma situação. De acordo com Piaget (1954), o interesse tem uma função regulatória na construção do conhecimento, aumentando ou diminuindo a quantidade de energia aplicada na interação com um objeto de conhecimento. Como alguns objetos são mais interessantes que outros, o aprendiz os coordena, construindo uma hierarquia pessoal de valores. Considerando a teoria de Piaget nosso principal universo de referência, o presente estudo tem por objetivo contribuir para o trabalho de educadores e psicólogos. A primeira parte da pesquisa consiste numa revisão bibliográfica sobre a teoria piagetiana da afetividade, sobre motivação e sobre aprendizado de línguas. A segunda parte traz os resultados de vinte entrevistas - nos moldes da Entrevista Clínica Piagetiana - sobre os valores atribuídos à língua estrangeira pelos alunos, relacionados à motivação, experiências, emoções, prática e metas.

Palavras-Chave: 1. Piaget 2. Língua Inglesa 3.Construção de Valores 4. Afetividade 


\begin{abstract}
The aim of this research is to investigate the relations between values construction and English language learning. Our society makes us believe it is very important to learn and speak fluently another language, specially English. Learning another language is highly beneficial academically, professionally, personally, and cognitively, as it enhances, for example, cultural awareness and language skills. However, students' interests seem to have been influenced mostly by extrinsic motivation, since many of them believe it is important to learn English in order to meet the market demand. Not being necessarily bad, the impact of this perspective should be discussed in terms of how these learners coordinate foreign language learning, personal interests and, consequently, values. It is known that more extrinsic motivation tends to focus on external reward, fast and practical results, while learning another language involves a complex, personal and reflexive knowledge construction. Piaget (1954) has shown that interest is the fuel of knowledge construction. Without interest, the learner would never make effort to make sense out of the experience. According to Piaget (1954), interest has a regulatory function, increasing or decreasing the amount of energy used in the interaction with an object of knowledge. Some objects may be more interesting than others and the learner coordinates them, constructing a hierarchy of personal values. Taking the theory of Piaget as our main universe of reference, the present study aims to contribute with the work of educators and psychologists. The first part of the research displays a bibliographical review on affectivity in Piagetian theory, on motivation, and also on language learning. The second part presents the results of twenty interviews similar to Piagetian Clinical Interviews - about values which students attribute to the foreign language, connected to their motivation, emotion, experiences, practice and goals.
\end{abstract}

Keywords: 1. Piaget 2. English Language 3. Values Construction 4. Affectivity 


\section{Sumário}

\section{PRIMEIRA PARTE: EMBASAMENTO TEÓRICO}

1. Apresentação ...................................................................................... 12

2. Estado da Arte ................................................................................ 14

3. Construção de valores: Introdução....................................................... 18

4. A busca por uma língua universal ...................................................... 21

5. Língua estrangeira: o discurso da obrigação em conhecê-la.................... 28

6. A aprendizagem da língua inglesa em escola de idioma ....................... $\quad 32$

6.1. Principais características dos aprendizes adultos................................. 36

6.2. A questão da motivação.....................................................................

7. Aquisição de língua materna versus aquisição de L2: alguns aspectos

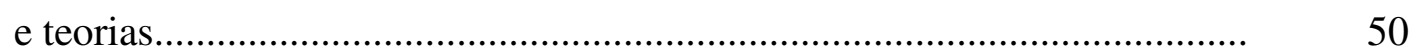

8. A dimensão cultural da língua: a experiência do estranhamento ............. 58

9. Dificuldades de aprendizagem da língua estrangeira por adultos ........... 61

10. Língua estrangeira como objeto de conhecimento: uma visão

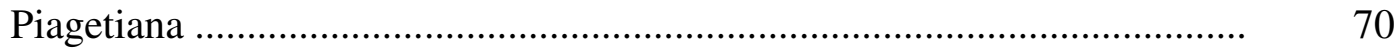

11. Introdução à teoria de Jean Piaget: construção da inteligência e da Afetividade ............................................................................................

11.1. Construção da inteligência .............................................................

11.2. Relações entre afetividade e inteligência .............................................

11.3. Afetividade e construção de valores ................................................... 77

12. Considerações Preliminares ............................................................... 80

SEGUNDA PARTE: PESQUISA DE CAMPO

1. Objetivos da pesquisa .................................................................... 81

2. Método ......................................................................................... 81

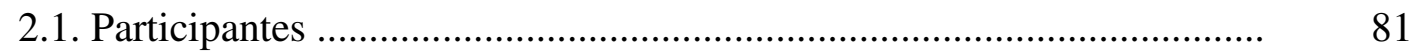

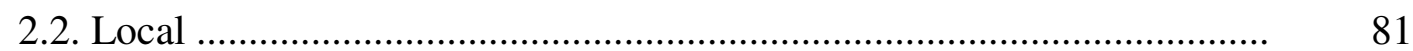

2.3. Procedimentos para coleta e análise dos dados ................................... $\quad 82$

3. Estudo Piloto: entrevistas e resultados preliminares ............................. $\quad 85$

3.1. Participantes - Estudo Piloto ............................................................... $\quad 85$

3.2. Procedimentos para coleta de dados - Estudo Piloto ........................... 85

3.3. Reordenação das questões - Estudo Piloto ......................................... 86

3.4. Procedimentos para a análise de dados - Estudo Piloto ....................... 87

3.4.1. Categorias de análise - Estudo Piloto ............................................... 88

3.4.2. Análise dos dados preliminares e discussão - Estudo Piloto ............. 89

4. Considerações sobre o Estudo Piloto .................................................... 93

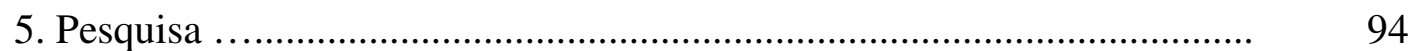

5.1. Participantes .......................................................................... 94 
5.2. Procedimentos para coleta de dados

5.3. Procedimentos para a análise de dados ............................................... 99

5.3.1. Leitura dos Quadros ..................................................................... 100

5.3.2. Tabelas de Frequência .................................................................... 104

5.3.3. Categorias de análise ................................................................... 104

5.4. Análise dos dados e discussão ........................................................ 106

5.4.1. Categoria Motivação ....................................................................... 114

5.4.2. Categoria Sentimentos ............................................................. 118

5.4.3. Categoria Valorizações ..................................................................... 125

5.4.4. Categoria Metas ...................................................................... 131

5.4.5. Relações entre as línguas ............................................................... 134

6. Estudos de caso ................................................................................. 137

6.1 Primeiro Estudo de Caso: F9 ............................................................... 137

6.2 Segundo Estudo de Caso: F10 ........................................................... 139

6.3 Terceiro Estudo de Caso: M7 .............................................................. 141

6.4 Quarto Estudo de Caso: M9 ................................................................ 144

7. Considerações Finais ......................................................................... 146

8. Referências ..................................................................................... 148

Anexos - TCLE e Quadros de entrevistas .............................................. 152 


\section{Apresentação}

Há muito tenho me interessado em procurar entender o fracasso escolar em adultos, quando expostos ao aprendizado de uma segunda língua ${ }^{1}$, no caso, a língua inglesa. Tenho me perguntado, repetidas vezes, por que algumas pessoas - bem-dotadas intelectualmente parecem não aprender. Esta questão, no mínimo intrigante, é o que move a presente pesquisa de Mestrado, intitulada "O valor de aprender inglês: construção de valores por adultos estudantes de língua inglesa sob a ótica piagetiana", estudo iniciado a partir da pós-graduação em Psicopedagogia, com a monografia intitulada "Seu desejo é uma ordem: ensaio sobre o papel do desejo na aprendizagem da língua inglesa por adultos à luz da psicanálise”, em 2010.

O fracasso na aprendizagem em adultos é quase tão frequente e frustrante quanto em crianças. Porém, em relação a adultos, a preocupação dos professores com esse fracasso é muito menor, talvez porque se pense que um adulto deva ser capaz de notar suas deficiências e saber lidar com elas, quase como se auto corrigir.

Há muitos estudos sobre dificuldades de aprendizagem em crianças e os professores estão cada vez mais preocupados em saber, pelo menos, como detectar falhas no processo escolar, a fim de achar soluções melhores e mais eficazes. Mas, à medida que a idade aumenta, essa preocupação parece diminuir. Talvez porque professores de cursos especializados, como idiomas, têm pouca ou nenhuma noção de como lidar com a dificuldade, isso sem contar a falta de formação pedagógica, ou ainda, quando formados em Letras, a formação não deixa de ser estritamente pedagógica (do grego paidós = criança). Em The Modern Practice of Adult Education, Malcolm S. Knowles (1970), escreve sobre essa questão. Ele afirma que, até então, só havia um modelo de ensino, originado as escolas monásticas da Europa entre os séculos sete e doze, posteriormente adotado nas escolas seculares e, por fim, nas universidades. Era o modelo da pedagogia, do grego paidós (criança) e agogós (conduzir), ou seja, um modelo voltado à educação de crianças. As ideias pedagógicas foram inicialmente baseadas nas observações dos frades responsáveis pela educação daqueles sujeitos bastante jovens e consistiam em desenvolver habilidades como ler e escrever. Evidentemente, esse ensino era voltado às questões religiosas e, portanto, muito mais centrado na aquisição de conteúdo do que no desenvolvimento de competências. Porém, após a Segunda Guerra, a educação de adultos passa a ser mais sistemática e esse modelo

\footnotetext{
${ }^{1}$ As expressões segunda língua, L2 e língua estrangeira serão utilizadas intercambiavelmente ao longo deste trabalho.
} 
torna-se ineficiente para dar conta da nova demanda.

Pesquisando, então, sobre dificuldades na aprendizagem de línguas por adultos, tema que será abordado mais à frente, deparamo-nos com outro tema relevante para formação do professor e no contexto de ensino-aprendizagem: a motivação para o aprendizado. A motivação relaciona-se às estratégias de aprendizagem do aluno, às estratégias de ensino do professor, ao ambiente de aprendizagem, ao tipo de metodologia (no caso do ensino de línguas) e às questões afetivas, ligadas não só aos "sentimentos" do aluno em relação ao objeto de conhecimento, mas também aos valores atribuídos pelo aprendiz a esse objeto de conhecimento. Desse modo, encontramos nas pesquisas de Ryan \& Deci (2000), sobre motivação intrínseca e motivação extrínseca, base teórica para o presente trabalho. Dentre as pesquisas brasileiras, destacaremos as de Guimarães \& Boruchovitch (2004), Cardoso \& Bzuneck (2004), Zenorini, Santos \& Monteiro (2011).

Associando motivação à ideia de "energética da ação", encontramos na formulação piagetiana de valor, terreno propício para o desenvolvimento dessa pesquisa, delimitando, assim o objeto de nosso estudo: a construção de valores por adultos estudantes de língua inglesa.

Em seguida, apresentamos o Estado da Arte sobre Educação de Adultos e sobre Construção de Valores sob a ótica piagetiana. 


\section{Estado da Arte}

Em trabalho apresentado na XXII Reunião Anual da ANPEd, Oliveira (1999), discutindo o tema da educação de jovens e adultos, afirma que os processos de aprendizagem e de construção de conhecimento por adultos são muito menos explorados na literatura psicológica do que os processos infantis. Citando Palacios (1995), Oliveira afirma, ainda, que a idade adulta é, em geral, encarada como um período de estabilidade, sem mudanças significativas. Essa visão do adulto vem ao encontro de nossa prática.

Ainda, pesquisando sobre o Estado da Arte em relação à educação de adultos no Brasil, encontramos um trabalho coordenado por Sérgio Haddad (2000), sobre a produção discente da pós-graduação em educação no período entre 1986 e1998. Os resultados mostram uma ampla maioria de estudos concentrada nas práticas de alfabetização e escolarização de jovens e adultos, no ensino supletivo ou regular noturno, nos níveis fundamental ou médio. Quanto às práticas pedagógicas, uma parcela significativa dos estudos é dedicada à aprendizagem da leitura e escrita e da matemática.

Ou seja, a produção de conhecimento sobre educação de adultos em outros espaços, como os cursos livres ou especializados, sobre as vicissitudes desse aprendizado e sobre os processos cognitivos e afetivos envolvidos nesse processo no período adulto ainda é escassa.

Para pesquisar especificamente sobre língua inglesa, afetividade e construção de valores, lançamos mão da Biblioteca de Teses e Dissertações da Universidade de São Paulo e da Busca Integrada da USP, portal que integra os recursos informacionais do Sistema Integrado de Bibliotecas da USP (SIBiUSP), mostrando os recursos impressos e digitais disponíveis no Sistema Integrado de Bibliotecas, entre artigos, livros, teses e dissertações, tanto da USP quanto de outras universidades. As Bases de Dados do SIBiUSP são as seguintes: Directory of Open Access Journals (DOAJ); OneFile (GALE); TDX; NDLTD Union Catalog; JSTOR; Dialnet; Diposit Digital de la Universitat de Barcelona; SciELO Brazil (Scientific Electronic Library Online); J STAGE (Japan Science and Technology Agency).

Buscando através de várias palavras-chave, primeiramente na Biblioteca de Dissertações e Teses da USP, obtivemos os seguintes resultados:

- $\quad$ Piaget: 44 dissertações / 27 teses

- $\quad$ Língua estrangeira: 94 dissertações / 48 teses

- $\quad$ Escola de idiomas: 3 dissertações 
- Aprendizagem de língua inglesa: 6 dissertações / 1 tese

- $\quad$ Língua inglesa / afetividade: 0

- Inglês / afetividade: 0

- $\quad$ Língua inglesa / valores: 0

- $\quad$ Inglês / valores: 0

- $\quad$ Língua inglesa / valorização afetiva: 0

- Inglês / valorização afetiva: 0

- Afetividade: 34 dissertações / 36 teses (1 dissertação sobre ensino e aprendizagem de língua estrangeira)

- Valorização afetiva: 1 tese (tese de Flory sobre bilinguismo)

- $\quad$ Inglês / construção de valores: 0

- $\quad$ Língua inglesa / construção de valores: 0

Em seguida, repetimos a busca em SIBiUSP, e obtivemos os seguintes resultados:

- $\quad$ Piaget: 3766

- $\quad$ Língua estrangeira: 2395

- $\quad$ Escola de idiomas: 223

- $\quad$ Aprendizagem de língua inglesa: 605

- Afetividade: 1018 (resultados envolvem diversas áreas do conhecimento)

- Língua inglesa / afetividade: 16 (4 sobre ensino e aprendizagem de língua inglesa)

- Inglês / afetividade: 37 (5 artigos sobre ensino e aprendizagem de língua inglesa)

- Inglês / valores: 4512 (resultados envolvem diversas áreas do conhecimento)

- Língua inglesa / valores: 300 (aproximadamente 50 resultados envolvendo ensino e aprendizagem)

- Valorização afetiva: 132 (1 tese sobre bilinguismo - Flory / 1 artigo sobre bilinguismo - Megale)

- $\quad$ Língua inglesa / valorização afetiva: 8 (1 artigo sobre bilinguismo - Megale)

- Inglês / construção de valores / Piaget: 16 (nenhum resultado sobre construção de valores em ensino e aprendizagem de língua estrangeira)

- Língua inglesa / construção de valores / Piaget: 7 (nenhum resultado sobre construção de valores em ensino e aprendizagem de língua estrangeira) 
- $\quad$ English / affectivity: 2266

- $\quad$ English learning / affectivity / Piaget: 43 (1 artigo sobre aquisição de línguas)

- Values construction / Piaget: 21 (nenhum resultado sobre construção de valores em ensino e aprendizagem de língua estrangeira)

Dentre as produções encontradas através das palavras-chave "valorização afetiva" está a tese de doutorado de Flory (2008), sobre o bilinguismo precoce, que inclusive será citada mais à frente.

Cientes de que esse levantamento não representa toda a produção nacional / internacional, nosso propósito foi ofertar uma visão geral do que tem sido produzido a respeito dos assuntos relacionados ao presente trabalho, que pretende contribuir para a produção de conhecimento sobre educação de adultos, especialmente pensando nas dificuldades encontradas pelos profissionais da educação no terreno dos chamados "curso livres de idiomas".

Pela experiência de doze anos em ensino de línguas, percebemos certo pudor em se discutir questões da ordem do fracasso e da frustração. É tão delicado para o professor tocar nesse assunto quanto difícil para o aluno adulto enxergar ou admitir tal problema. Por um código de silêncio mútuo, as frustrações vão se repetindo. Tal fato pode ser explicado pelo fato de o aluno adulto ser visto pelo professor, muitas vezes, como um sujeito já ciente de suas escolhas e com maior capacidade de reflexão sobre o conhecimento de modo geral e sobre seus próprios processos de aprendizagem, tudo isso reforçado por aquela crença da vida adulta como um período de estabilidade, citada anteriormente. Dessa forma, o professor não se sente confortável em apontar "falhas" do aluno ou não acha necessário fazer suas observações, mesmo sabendo que o papel do professor nem é apontar "falhas", expor o aprendiz, diminuí-lo, mostrar suas fraquezas; é exatamente o contrário, é procurar o que não está funcionando para poder ser revisto, apontando - sim - as rachaduras no processo. E o que não está funcionando pode ser melhor visualizado de fora.

Quanto ao aluno, a vergonha por não entender certos conteúdos torna-se uma das principais barreiras para seu aprendizado. O peso de ser um adulto, bem-sucedido em outras áreas, em contraste com dificuldades enfrentadas na sala de aula muitas vezes o leva a desistir do curso. Em contrapartida, há também casos em que o aluno não aceita a intervenção do professor, pelo mesmo motivo: já é um adulto, independente, ciente de seus problemas e responsabilidades e não precisa ser "controlado" pelo professor.

Isso não quer dizer que o fracasso seja ignorado em escolas de idiomas. Ao contrário, 
é bastante discutido, embora superficialmente, algumas vezes procurando apenas uma maneira de manter o aluno (pagante) na escola. É nesse contexto que se justifica um estudo sobre construção de valores na aprendizagem de uma língua estrangeira, por adultos, em cursos de línguas.

O presente estudo propõe-se, então, a investigar as valorizações afetivas dos estudantes adultos em relação ao aprendizado da língua estrangeira, especialmente sob a ótica piagetiana da construção do conhecimento e da afetividade, procurando entender a construção desses valores a partir das motivações que levaram esses aprendizes a ter contato com o novo idioma, de modo a contribuir com o trabalho dos profissionais da Psicologia, da Educação e da Psicopedagogia.

O texto foi estruturado a partir de discussões sobre a crença na importância do aprendizado da língua inglesa, que aparece logo na introdução desse trabalho, em seguida discute-se a relevância da língua inglesa no contexto atual, a aprendizagem da língua inglesa em escolas de idiomas, as motivações dos aprendizes adultos, além de algumas questões sobre dificuldades de aprendizagem de L2, sobre a dimensão cultural da língua e uma pequena introdução às teorias de aquisição de L2. A seguir apresenta-se a teoria piagetiana da construção do conhecimento e da afetividade, que embasa o presente trabalho. Em seguida, será apresentado o Método da pesquisa, a pesquisa piloto e, finalmente, os resultados obtidos a partir de entrevistas realizadas com estudantes adultos, em uma escola de idiomas de São Paulo, além de suas possíveis implicações no campo educacional. 


\section{Construção de Valores: Introdução}

A sociedade moderna nos faz crer que é importantíssimo aprender uma língua estrangeira, especialmente inglês. Ninguém ignora que aprender uma nova língua é extremamente benéfico do ponto de vista acadêmico, profissional, social e, principalmente, cognitivo, já que esse aprendizado melhora, entre outras coisas, as próprias habilidades linguísticas e amplia as possibilidades de interação social.

Porém, com o grande número de pessoas fazendo pós-graduação e o mercado de trabalho saturado de especialistas, há que se encontrar novas formas de seleção. Ou seja, conhecer uma língua estrangeira, no caso do inglês, parece não se tratar mais de difusão cultural, do "processo pelo qual os elementos ou sistemas de cultura se espalham." (Kroeber APUD Ortiz, 2008:74). Dominar inglês, especialmente quanto à habilidade da fala, tem sido, no Brasil, critério de seleção. Esse fato pode estar mudando a percepção da sociedade em relação ao aprendizado de línguas, de maneira que os aprendizes adultos parecem estar gradativamente perdendo seus objetivos pessoais em relação à nova língua.

Muitos desses estudantes não precisariam, por exemplo, dominar inglês em nível avançado. Precisariam de um conhecimento instrumental para dar conta de algum material escrito, geralmente técnico, de sua própria área de atuação. De qualquer forma, todos querem ser fluentes - o que é ótimo - porém querem isso o mais rápido possível e sem muito esforço, em grande parte para corresponder às expectativas do mercado. Se por um lado todo investimento em educação colabora na construção de um país de pensantes, por outro, a maioria dos sujeitos que se matriculam em cursos de idiomas não têm a menor ideia do que é falar uma nova língua, de como isso vai mexer com eles, de como isso demanda tempo tempo de estudo, de reflexão, de associação e construção de novas ideias e valores, de acomodação dessas ideias para uso posterior. Ou seja, os interesses dos alunos, aparentemente, estão passando de uma motivação mais intrínseca para uma motivação mais extrínseca, em razão das demandas de mercado.

Antes de mais nada, não estamos afirmando que a motivação extrínseca seja pior ou melhor que a motivação intrínseca, em termos de aprendizagem. Na verdade, seja intrínseca ou extrínseca, a motivação depende do contexto em que está inserida. Nosso interesse é pensar sobre o impacto da perspectiva acima mencionada e discutir como os aprendizes têm lidado com a língua estrangeira sob tal perspectiva, especialmente em termos de construção de valores, já que dominar uma língua estrangeira a ponto de poder expressá-la através da fala exige, além de um alto grau de engajamento, certa dose de aceitação de si mesmo e do outro, 
na medida em que se descobrem novas formas de expressão cultural. É, portanto, uma construção pessoal, reflexiva e complexa, pois cada língua carrega sua cultura e seus valores.

Piaget (1954) formula sua concepção de valor baseado nas ideias de Pierre Janet e de Edouard Claparède, para quem o interesse (ligado à afetividade) desempenha um papel essencial no funcionamento intelectual.

Claparède defende que toda conduta supõe uma meta e uma técnica. A meta, ou finalidade, representa uma intenção mais ou menos consciente, ligada à afetividade (interesse), enquanto a técnica representa o conjunto de meios empregados para realizar a meta e está, desta forma, ligada à cognição (percepção, inteligência). Porém, para Piaget, que se opunha a visões dicotômicas, tal divisão é muito esquemática e argumenta que, mesmo o interesse sendo combustível para a meta, não é suficiente para defini-la, pois essa definição depende também dos meios intelectuais de que dispõe um sujeito naquele momento. Equivale a dizer: uma criança no período pré-operatório, por exemplo, não dispondo ainda de um pensamento reversível, não definirá uma meta baseada na lógica operatória. Quanto à técnica, também não pode ser apenas cognitiva, pois, para atingir a meta, o sujeito emprega mais ou menos energética. Ou seja, há regulação afetiva, envolvendo tendências como a perseverança.

Para Janet, toda conduta pressupõe dois tipos de ação: uma primária e uma secundária. A ação primária é a relação entre o sujeito e os objetos (que podem ser coisas ou pessoas). É a atuação do sujeito sobre esses objetos, portanto, cognitiva. A ação secundária é o resultado dessa atuação, ou seja, a reação do sujeito diante de sua própria ação. Corresponde a todas as regulações envolvidas nesse processo: esforço, cansaço, fracasso, êxito, alegria, decepção, etc. É a energética da ação, logo, afetiva. Como a formulação de Claparède, a de Janet também é dicotômica. Piaget defende que a inteligência atua sobre os objetos, mas a afetividade é que os seleciona. Na ação secundária há, na verdade, dupla regulação: regulação interna e trocas regulatórias com o meio (nas quais os elementos cognitivos estão envolvidos, pois a interação com o meio se dá através da inteligência e da percepção).

Piaget associa, então, o sistema de regulações (energética) proposto por Janet à ideia de interesse, de Claparède, e formula sua concepção de valor, definido como "aspecto qualitativo do interesse", "expansão da atividade do eu na conquista do universo", "intercâmbio afetivo com o exterior".

Dessa forma, Piaget (1954) liga valores a interesses, na medida em que interesse é o combustível para a construção de conhecimento e o valor é seu aspecto qualitativo. Sem interesse, o aprendiz não se esforça para resolver um problema. O interesse tem, portanto, uma função regulatória, aumentando ou diminuindo a quantidade de energia usada na 
interação com o objeto de conhecimento. Como alguns objetos são mais interessantes que outros, o aprendiz tende a coordená-los qualitativamente, num sistema de valores pessoais, no qual alguns valores assumem uma posição mais central enquanto outros permanecem em posições periféricas.

O foco desse estudo está justamente nesse interesse, do ponto de vista afetivo, coordenado num sistema de valores que, por sua vez, será construído pelo aprendiz no contato com a nova língua, pois acreditamos que a qualidade desse interesse - que é, em última análise, o valor - está diretamente ligada ao aumento ou diminuição do fracasso e das frustrações do aprendiz de línguas e às suas projeções futuras.

Ressalta-se que o objetivo do presente estudo não é provar que aprendizes cujos sistemas de valores construídos sugerirem "valorizações mais periféricas", de acordo com os critérios adotados, serão aqueles que terão piores desempenhos acadêmicos, mas sim que a possibilidade de perceber e entender a dinâmica desses sistemas de valores pode fornecer elementos para a reflexão dos professores a respeito do processo de ensino e aprendizagem, bem como, ao ser trazida à consciência pelo aluno, servir como um regulador de seu aprendizado. Para complementar, então, a investigação teórica sobre os interesses, serão trazidos os estudos sobre motivação de Ryan \& Deci (2000), Guimarães \& Boruchovitch (2004), Cardoso \& Bzuneck (2004), Zenorini, Santos \& Monteiro (2011).

A seguir, breve discussão sobre as razões da proeminência da língua inglesa e de que maneira configurou-se como uma língua de destaque no cenário atual. 


\section{A busca pela língua universal}

Na primeira parte de seu livro A diversidade dos sotaques, Renato Ortiz (2008) discorre sobre as razões pelas quais a língua inglesa veio assumir um lugar de destaque no cenário atual, em termos de comunicação de modo geral. Apesar de seu enfoque nas Ciências Sociais, o livro não deixa de ser preciosa fonte de estudo linguístico. Passando pelo mito bíblico de Babel, pelos filósofos iluministas e pelos linguistas, Ortiz cita a busca pela língua adâmica e, depois, discute a busca pela língua universal.

A língua adâmica, língua hipotética falada por Adão e Eva no Jardim do Éden, ou seja, a língua original, fundadora - que, para Walter Benjamin, caracteriza-se pela convergência absoluta entre nomes e coisas - seria a portadora da verdade, da clareza, da transparência. Mas, depois da presunçosa tentativa humana de construir uma torre para alcançar os céus, o Senhor confundiu os homens através de sua língua, de modo que um não compreendesse mais o outro. A pulverização dessa língua representa, nesse contexto, uma calamidade, um infortúnio: perdidos numa multiplicidade de significações, os homens não puderam concluir seu intento.

Uma das mais antigas ambições humanas, a língua universal, uma língua natural ou artificial, seria aquela que pudesse expressar com precisão a realidade, sem ambiguidades, um “retorno” à língua adâmica. Isso traria grande benefício para a ciência: as ideias, os conceitos, as teorias estariam livres de qualquer dúvida e, os cientistas, de qualquer perplexidade. Para alguns - com uma visão ingênua - essa possibilidade de se exprimir com exatidão evitaria diversos mal-entendidos entre os povos, inclusive a guerra. Desse ponto de vista, o Babelismo, ou seja, a existência de diversas línguas, é concebido como uma "maldição".

Quando Descartes é consultado por Mersenne a respeito da eventual
construção de uma língua universal, ele responde: 'se alguém explicasse
quais são as ideias simples que estão na imaginação dos homens, aquelas que
compõem tudo aquilo o que eles pensam, eu ousaria esperar que uma língua
universal, fácil de ser aprendida, falada e escrita, pudesse, principalmente,
auxiliar o julgamento, representando-lhe as coisas de tal forma que lhe seria
quase impossível se enganar'. (Ortiz, 2008:20)

Aqui, caberia perguntar como uma língua que pretendesse expressar "as ideias simples" poderia ir além da lógica e da praticidade concreta e imediata para traduzir, por exemplo, formulações hipotéticas do pensamento humano, capazes de cogitar o inexistente? Como seria possível expressar as invenções se só o real pudesse ser representado? Como seria 
possível representar a diversidade de experiências humanas? Considerando a grande capacidade de adaptação do ser humano, poderíamos afirmar que todas as experiências humanas convergem para um mesmo ponto? Todas as questões levantadas fazem parte do universo da complexidade, e por isso talvez nenhum linguista ou filósofo tenha conseguido êxito na busca por exatidão linguística.

Não se pode negar que a unidade linguística seja uma aspiração humana. A língua é uma expressão individual que destaca e subjetiva cada um no contato com o mundo, mas, também, é uma ponte que liga e une uma comunidade inteira. Nesse sentido, a língua é um bem comum, impelindo cada integrante dessa comunidade a partilhar seus projetos, ideias e ideais.

Para se constituir numa totalidade integrada, a nação deve necessariamente soldar os indivíduos em torno de um bem simbólico compartilhado em ampla escala: o monolinguismo. Falar a mesma língua é o equivalente a pertencer a uma mesma comunidade, viver um destino comum. (Ortiz, 2008: 26)

Em seu livro Storia linguistica dell'ltalia unita, Tullio De Mauro (1991) trata da história linguística da Itália desde a unidade política do país, em 1861, até a Segunda Guerra, considerando a língua italiana em relação aos problemas culturais e étnico-políticos da nação, as condições linguísticas do país nos anos de unificação política, os efeitos linguísticos das transformações sociais derivadas dessa unificação e, por fim, aborda as mudanças formais e funcionais no idioma dialetal e na língua comum, em um século de unificação.

Logo na primeira página, De Mauro (1991) cita o escritor e político Luigi Settembrini: "Vocês sabem que, quando um povo perdeu pátria e liberdade e está disperso no mundo, a língua ocupa o lugar de pátria e de tudo". ${ }^{2}$ A ligação entre língua e pátria - relação de estreita unidade - está na base do já mencionado mito da maldição babélica, pelo qual a divindade ultrajada pune os homens com a multiplicidade de línguas e, consequentemente, com a multiplicidade de nações.

Segundo De Mauro (1991), a ideia de unidade entre língua e nação ganhou força na Era Romântica, não por simples questão literária ou intelectual, mas política. A partir da segunda metade do século XVIII, não só na Europa, mas no Ocidente, o princípio de nacionalidade tornou-se grande estímulo político, já que a questão da liberdade humana

\footnotetext{
${ }^{2}$ Voi sapete che, quando un popolo ha perduto patria e libertà e va disperso pel mondo, la lingua gli tiene luogo di patria e di tutto. (Ricordanze della mia vita, 1879). Tradução nossa.
} 
colocava-se como questão de autonomia política de cada nacionalidade. Para realizar esse intento era preciso, também, aderir a uma tradição linguística, símbolo de uma unidade nacional.

Porém, apenas a unificação política não foi suficiente para aproximar a nação italiana em torno de uma língua comum. Mais à frente, De Mauro (1991) nos diz que, mesmo com a unificação política de 1861, faltou uma "força centrípeta", ligada à centralização demográfica, econômica, intelectual e política de um estado unificado, induzindo o país a orientar-se linguisticamente, algo que França, Espanha e Inglaterra já haviam conseguido. A primeira questão a se considerar é a grande quantidade de dialetos, muito diferentes uns dos outros, que historicamente prosperaram na península italiana. $\mathrm{O}$ autor destaca três grandes grupos: o setentrional, o toscano e o meridional. A variedade desses dialetos é resultado da diversidade de usos do latim nas diversas regiões, devido a séculos de história e limitados apenas pelo uso do próprio latim no meio jurídico e religioso.

Segundo Dardano e Trifone (1995), o isolamento desses dialetos dava-se em virtude da baixa frequência de trocas entre seus falantes, sobretudo porque apenas alguns poucos privilegiados tinham a possibilidade de viajar de uma região a outra. ${ }^{3}$

Paralelamente à imobilidade dos dialetos, o florentino afirmava-se como língua literária e escrita, especialmente depois das obras de Dante, Petrarca e Boccaccio.

Dardano e Trifone (1995) listam uma série de motivos que - reforçados pela unificação política - culminaram na unificação linguística:

1) a educação formal, que se torna obrigatória;

2) a emigração interna;

3) o desenvolvimento das cidades;

4) o serviço militar

5) a necessidade de compreender assuntos relacionados ao Estado Novo.

Como se vê, a unificação política propiciou, antes de tudo, deslocamentos de pessoas e consequente trocas entre elas. Volta-se, então, à ideia de língua como "ponte”, como

\footnotetext{
${ }^{3}$ Nei secoli passati i dialetti italiani si conservavano maggiormente nel tempo, mutavano con grande lentezza perché mancavano occasioni di scambio tra gli abitanti delle diverse regioni d'Italia. Soltanto pochi privilegiati avevano occasione di spostarsi da un paese all'altro per conoscere parlate diverse dalla própria. (Dardano e Trifone, 1995: 52)
} 
"facilitadora" de trocas de experiências humanas. Assim, partilhar a língua é fator de desenvolvimento sócio-cultural e econômico.

De Mauro (1991) discorre também sobre a obrigatoriedade da instrução formal para as camadas sociais mais baixas como uma forma de difusão do italiano "padrão" e aponta os principais obstáculos dessa prática: até 1861 quase $80 \%$ da população era analfabeta, ou seja, impossibilitada de ter contato com o uso escrito da língua; grande parte daqueles considerados alfabetizados eram, na verdade, semialfabetizados; mesmo os professores, em sua maioria, davam aulas em dialeto.

Dardano e Trifone (1995) acrescentam, ainda, um dado importante: depois da Segunda Guerra, o advento dos meios de comunicação, principalmente a televisão, propiciou grande difusão do italiano padrão, pois possibilitou a todas as classes sociais e faixas etárias o contato com a língua.

Acompanhando, mesmo que superficialmente, os esforços de unificação linguística na Itália, a princípio impulsionados pela ação política, pudemos entrever a importância da língua no processo de afirmação da soberania de uma nação. Por outro lado, verificamos o quanto é complexa a implementação de uma língua comum, "universal", na tentativa de conciliar toda uma multiplicidade de culturas e costumes, após séculos de uso de idiomas regionais.

A partir do século XX, a busca pela língua universal cedeu lugar a uma visão "ecológica", de preservação das línguas, agora vistas como patrimônio cultural da humanidade. ${ }^{4}$ O Babelismo passa de "maldição" a "manifestação da diversidade".

O monolinguismo começou a ser questionado não só pela demanda "ecológica", de preservação, mas também pelos estudos sobre a aprendizagem de línguas estrangeiras e os possíveis benefícios cognitivos desse aprendizado.

Até a década de 60, muitas pesquisas apontavam desvantagens associadas ao bilinguismo. Duvidava-se que haveria ganhos cognitivos quando, por exemplo, uma criança aprendia duas línguas ao mesmo tempo. Ao contrário, professores e especialistas recomendavam aos pais de nacionalidades diferentes que adotassem uma única língua, para evitar confusões por parte da criança, especialmente no momento da alfabetização. Pesquisas mais recentes, porém, indicam que há vários ganhos - cognitivos, pessoais, sociais

\footnotetext{
${ }^{4}$ Note-se que, mesmo em meio a tal cenário "ecológico", de preservação das línguas, o médico polonês Lázaro Zamenhof idealizou o Esperanto - língua artificial planejada com o intuito de facilitar a comunicação entre os povos de diferentes países e culturas - divulgando-o a partir de 1887. (Fonte: www. esperanto.org.br)
} 
- tanto para crianças como para adultos. Aliás, o bilinguismo tem sido objeto de interesse por parte de muitos pesquisadores.

Em sua tese de doutoramento intitulada "Influências do bilinguismo precoce sobre o desenvolvimento infantil: uma leitura a partir da teoria da equilibração de Jean Piaget", partindo da perspectiva piagetiana de que o ser humano nasce com potencialidades as quais serão ou não atualizadas no contato com o meio, Flory (2008) nos faz refletir sobre a hipótese de que o acesso a mais de um sistema linguístico na infância possa influenciar, além de outras coisas, a construção da maneira de organizar e perceber o mundo pela criança. Para a pesquisadora - a partir da Teoria da Equilibração de Piaget - no bilinguismo, gradativamente, as duas línguas integrariam um sistema linguístico maior, sem que com isso fossem confundidas ou misturadas. Desse modo, o bilinguismo ampliaria as possibilidades do ser humano, na medida em que ofereceria mais desafios à equibração desse sujeito em contato com o meio pois, além de ter que identificar diferentes formas de discurso e classes de objetos para se comunicar, ele precisaria, ainda, diferenciar entre as línguas e os contextos envolvidos. Dito de outra forma, na medida em que dispõe de mais variáveis, o sujeito vê a necessidade de criar estratégias de assimilação e acomodação para se reequilibrar diante dessas demandas do ambiente.

Em seu ensaio "A relação bilingüismo-cognição no processo de alfabetização e letramento", Nobre e Hodges (2010) procuram desmistificar algumas destas concepções sobre a vivência bilíngue como prejudicial ao desenvolvimento cognitivo das crianças. Citando Bialystok (2007, 2008), as pesquisadoras encontraram evidências de que as crianças bilíngues apresentam ganhos nas funções executivas, tais como: atenção, inibição, monitoramento e alternância de tarefas, e acrescentam que esse impacto no desenvolvimento cognitivo perdura durante toda a vida, inclusive quanto à proteção contra o declínio dessas funções na velhice.

Voltando à crença na importância do aprendizado da língua inglesa, especificamente, essa extrapola os níveis cognitivos, já que a "difusão" dessa língua na sociedade tem tomado contornos de obrigatoriedade. Com a expansão econômica e política americana e a exportação dos bens culturais desse país, como o entretenimento de modo geral - o cinema, a música além dos avanços tecnológicos, a língua inglesa passou a figurar no cenário mundial como referência: "A legitimidade do inglês é tal que prescinde do entendimento dos que o desconhecem" (Ortiz, 2008:85). Ou seja, inglês virou sinônimo de qualidade mesmo para quem não conhece a língua.

Além dessa presença nos meios de comunicação, outro aspecto colaborou para o destaque do inglês dentre as línguas do mundo: sua suposta simplicidade. Essa crença 
mostrou-se presente no imaginário dos estudantes entrevistados na presente pesquisa. Conforme veremos, 20\% dos participantes atribuíram - espontaneamente - à língua inglesa essa pretensa característica. Apesar de parecer um número estatisticamente baixo, tendo sido um dado espontâneo, não tivemos acesso à opinião dos $80 \%$ dos participantes restantes.

Tal crença deve-se, em parte, ao fato de haver menos inflexões verbais e nominais no idioma inglês do que nas línguas latinas, por exemplo. Por outro lado, enquanto em português há seis tempos verbais no modo indicativo, há doze em inglês. Isso significa que o aprendiz precisará reorganizar toda sua visão temporal de mundo no novo (e em qualquer) idioma. Dito de outra maneira, pode-se expressar qualquer ação em qualquer língua, a questão é "como" cada língua resolve esse problema. Pode parecer simples, mas requer esforço reflexivo bastante intenso, pois apenas a tradução literal não encerrará o problema. Quanto à fonética, também considerada "simples" por vários especialistas defensores do inglês como uma língua mundial, constatamos que há mais sons de vogal em inglês do que em português, italiano ou espanhol, o que pode tornar árdua a pronúncia precisa do idioma inglês para os nativos dessas línguas latinas.

Enfim, o argumento da "simplicidade" de um idioma, por si só, não poderia ser suficiente para sua eleição como um idioma global, uma vez que uma língua reflete as experiências de uma determinada cultura. Refletindo de acordo com o interacionismo de Piaget, cada ser humano se desenvolve de acordo com as demandas de seu meio; assim, o fácil ou o difícil dependeriam dos recursos - do repertório - de que cada sujeito dispõe na interação com o ambiente. Nesse caso, os recursos da cultura em que está imerso.

O renomado linguista britânico David Crystal resume:

Uma língua não se torna global por causa de suas propriedades estruturais, pelo tamanho de seu vocabulário, ou por ter sido associada a uma grande cultura ou religião... Uma língua torna-se internacional por uma razão maior: o poder político de seu povo, especialmente seu poderio militar... Mas o domínio internacional de uma língua não decorre apenas da força militar. $\mathrm{O}$ poder militar de uma nação pode impor uma língua, mas é necessário um poderio econômico para mantê-la e expandi-la." (Crystal APUD Ortiz, 2008: 73)

Por fim, é importante lembrar que a escolha do idioma inglês para unir os diversos povos, cada um com sua cultura e com sua forma de expressão linguística, também traz consequências para o próprio idioma em questão. Ortiz nos lembra: “A diversidade dos sotaques é o preço pago por sua hiper-centralidade" (2008:82). Dito de outra forma, sob uma perspectiva que combina com nossa pesquisa, a língua inglesa como meio de comunicação 
"horizontal", que atravessa fronteiras para "unir" os povos, também sofre transformações pois, nesse contexto, é frequentemente aprendida já na idade adulta e, consequentemente, acaba sendo assimilada dentro de uma cultura-mãe já formada, quase tendo que se "moldar" à língua e cultura maternas de quem a aprende, sem formar aqueles sistemas independentes, integrantes de um sistema maior, de que nos fala Flory (2008). Quando isso acontece, quando a língua materna se afirma como base para a segunda língua, o aprendiz ou falante operam a língua estrangeira de maneira mais instrumental, permanecendo limitados às possibilidades de sua própria língua e até mesmo transferindo essas propriedades para a língua estrangeira.

A seguir, discutiremos o papel da mídia e das ideias de "globalização" e de "sociedade global" na produção de um discurso de obrigatoriedade do conhecimento de uma língua estrangeira, mais especificamente a língua inglesa, no contexto atual. 


\section{Língua estrangeira: o discurso da obrigação em conhecê-la}

Rogéria de Aguiar (2009), da Universidade Federal do Paraná, escreveu um interessante artigo - que dialoga com nossa pesquisa - intitulado "O discurso sobre a obrigação em aprender uma língua estrangeira". Pesquisando esse tema na mídia impressa no período de 1985 a 2005 e na publicidade de rua da cidade de Curitiba, a pesquisadora baseouse na Revista Veja, no Jornal a Gazeta do Povo, no Jornal Folha de São Paulo e na publicidade de rua de Curitiba. Segundo a autora, a proposta era encontrar enunciados que apresentassem regularidade de sentido, ou seja, uma formação discursiva. De acordo com Foucault, em $A$ Arqueologia do Saber:

No caso em que se puder descrever, entre um certo número de enunciados, semelhante sistema de dispersão, e no caso em que entre os objetos, os tipos de enunciação, os conceitos, as escolhas temáticas, se puder definir uma regularidade (uma ordem, correlações, posições e funcionamentos, transformações), diremos, por convenção, que se trata de uma formação discursiva. (p.43).

O que foi encontrado na pesquisa de Aguiar, em linhas gerais, é que muitas pessoas buscam o aprendizado de línguas estrangeiras com a certeza de "um futuro melhor", refletindo exatamente os enunciados publicitários, tomados como a verdade em si. Temos, assim, uma regularidade de enunciados, configurando um discurso. Ainda segundo a autora, esse discurso de obrigatoriedade respalda-se na ideia de um "mundo globalizado" e tem vários reflexos, como, por exemplo, a pressa em se aprender e a crescente procura por colégios bilíngues para as crianças, para que não cresçam - nas palavras dos próprios pais - como essa deficiência.

Interessante notar que a ideia de "mundo globalizado" parece ser um dos principais motores a impulsionar a procura pelo aprendizado de línguas estrangeiras. Segundo Montero (1997) - para quem o termo "globalização" carrega múltiplas significações, facilitando seu uso indiscriminado e pouco preciso - a questão da globalização liga-se a um sentimento dominante no mundo moderno: o da supressão da distância física. Para muitos estudiosos, segundo a autora, trata-se de um processo de "integração progressiva das culturas", apontando para o surgimento de uma "sociedade global".

(...) com a globalização dos últimos cinqüenta anos, a experiência social se modificou de tal maneira que o que há de mais íntimo e de mais distante estão agora, de súbito, diretamente conectados. (Anthony Giddens, 1990, APUD Montero, 1997). 
De certa maneira, a ideia de globalização não deixa também de ser uma "busca pelo universal", ${ }^{\prime 5}$, pelo que há de comum e pela possibilidade de união entre os povos, agora facilitada por esse encurtamento de distâncias, graças ao desenvolvimento tecnológico, principalmente dos meios de comunicação em massa e dos transportes. Porém, essa "sociedade global" está longe de ser atingida apenas por meio do encurtamento de distâncias físicas. Trata-se de uma ideia complexa, como nos explica Ianni (1994), em "Globalização: Novo paradigma das ciências sociais".

A essa altura da história, diz ele, as relações, os processos e as estruturas sociais, econômicas, culturais, etc., de âmbito mundial prevalecem sobre aqueles de âmbito nacional. Então, o paradigma clássico das ciências sociais, baseado na reflexão sobre a sociedade nacional, depara-se com a reflexão sobre uma sociedade global, que apresenta desafios empíricos e metodológicos, ou históricos e teóricos, que exigem novos conceitos, categorias e interpretações. Além disso, segundo o autor, os estudos sobre a sociedade global costumam dar prioridade a certos aspectos - econômicos, financeiros, tecnológicos, etc. - em detrimento de abordagens mais gerais, abrangentes e integrativas.

Ou seja, se por um lado a sociedade global encerra grandes desafios, por outro, parece privilegiar certos aspectos, orientando-nos principalmente na direção econômica.

Portanto, as questões que gostaríamos de suscitar tanto nos educadores quanto nos aprendizes referem-se ao processo de significação das ideias de "sociedade global" e, principalmente, de "globalização". Gostaríamos que se pudesse discutir o impacto e as nuances do conceito de globalização na nossa vida, na vida de cada comunidade, antes de comprar a ideia já pronta. Preciso aprender inglês porque o mundo é globalizado ou porque terei mais possibilidades de interação com o mundo? As duas perguntas são semelhantes em essência, porém diferem quanto à posição do sujeito. Acreditamos que é mais produtivo quando o sujeito toma uma atitude ativa diante de suas escolhas e, mais à frente, vamos discutir esse posicionamento em termos de motivação intrínseca e de valoração. Em resumo, o fato de o mundo ser globalizado pode, sim, influenciar nossas decisões, mas, antes de qualquer coisa, precisamos entender o que isso realmente significa.

Voltando ao texto de Aguiar (2009), quanto aos reflexos por ela mencionados, o mais preocupante é que o discurso da obrigação em aprender inglês parece estar suscitando a crença no monolinguismo como uma deficiência. Essa palavra nos remete à "ausência ou

\footnotetext{
${ }^{5}$ Por outro lado, pode ser uma busca pelo particular, na medida em que o mesmo encurtamento de distâncias possibilita o encontro do sujeito com aquilo que é novo, com culturas e realidades bastante diferentes da sua.
} 
disfunção de uma estrutura física ou mental", o que não caracteriza, de forma alguma, uma pessoa monolíngue.

No artigo "A língua inglesa como 'commodity': direito ou obrigação de todos", Clarissa Jordão (2004) discute o papel do aprendizado de línguas num mundo globalizado, onde o mercado se personifica, assumindo características humanas (tais como ficar nervoso, acalmar-se, alegrar-se), ditando regras e tendências, impondo padrões de comportamento e padrões educacionais.

A língua inglesa, que a pesquisadora compara às "commodities", ou seja, algo com valor de mercado, ocupando um lugar de destaque nesse mundo globalizado, assume uma posição ambígua, despertando suspeita - por um lado - e admiração e cobiça, por outro. Além disso, devido ao grande número de "usuários", mundo afora, a língua inglesa tem sofrido muitas alterações e está perdendo sua unidade, apesar de ainda prevalecer a crença num aspecto monocultural. Quanto à proficiência, percebe-se o estabelecimento de relações de poder entre falantes nativos e não-nativos, disputando a legitimidade de cada um ao apropriarse da língua.

Em termos educacionais, a pesquisadora traz à tona questões que, em sua (nossa) opinião, ainda precisam ser discutidas pelos educadores, como por exemplo: Qual é o objetivo desse aprendizado no Brasil? Esses objetivos são os mesmos em escolas públicas, privadas e em cursos de idiomas? O ensino de línguas deve ser obrigatório? Será que é tão importante assim falar inglês? Os europeus que não falam inglês não podem se considerar cidadãos do mundo? Em seguida, a pesquisadora esforça-se por comentar tais questões e lhes dar um direcionamento.

As questões colocadas por Jordão (2004) são bastante pertinentes e vêm ao encontro do que temos observado no ensino de línguas no país, além de dialogar com nossos próprios questionamentos e problematizações. Também queremos acessar as motivações dos aprendizes e entender seus objetivos em relação ao novo conhecimento linguístico, na tentativa de achar melhores caminhos educacionais.

Em "O discurso publicitário sobre as escolas de língua e a constituição da identidade", Maria José Coracini (2003) apresenta alguns resultados a respeito do discurso da mídia, representada pela publicidade de escolas de idiomas em algumas cidades, no Estado de São Paulo. A pesquisadora parte do pressuposto de que a mídia é, por um lado, influenciada pela sociedade e, por outro, influência na produção de subjetividade, via imaginário.

Uma das ideia que aborda é do discurso publicitário como produtor de necessidades necessidades que se tornam verdadeiras e reais, mas que, no final das contas, atendem a 
interesses preponderantemente econômicos. Em seguida, apresenta uma análise de folhetos publicitários de quinze escolas das cidades de Campinas, São Paulo e São José dos Campos, sob a ótica psicanalítica.

Um de seus argumentos mais interessantes é o de que as estratégias usadas pela publicidade, por um lado, agem no subconsciente dos clientes em potencial, e, por outro, provocam identificações pautadas nos valores defendidos pela sociedade.

Por fim, cientes de termos ofertado apenas um pequeno panorama do que se tem produzido a respeito da crença social na importância de se aprender a língua inglesa, passemos à discussão de alguns aspectos sobre o ensino de línguas estrangeiras em escolas de idiomas, sobretudo quanto à formação dos profissionais. 


\section{A aprendizagem da língua inglesa em escola de idiomas}

Durante um treinamento numa famosa franquia de escolas de inglês, a coordenadora pedagógica explicou o procedimento para solução de dúvidas gramaticais durante as aulas: os professores não deveriam nomear os termos da oração, apenas mostrar como usá-los, "na prática". Ou seja, não deveriam dizer que "Do", numa frase como "Do you study English?" é um verbo auxiliar, apenas dizer que "Do" marca uma pergunta. Esse procedimento, segundo a coordenadora, aproximar-se-ia da maneira como o aluno aprendera sua língua materna.

Alguém perguntou como proceder no caso de um aluno pedir explicações gramaticais ou no caso de continuar com dúvidas. A coordenadora, então, orientou simplesmente a repetir a explicação conforme a metodologia das aulas. O professor, insistindo na possibilidade de ter um aluno com uma dúvida persistente, voltou a questionar se haveria algum outro procedimento metodológico. Os demais professores, participantes da reunião, puseram-se a rir e a coordenadora respondeu: "Isso não vai acontecer".

O exemplo acima ilustra duas características presentes em grande parte das escolas de idiomas de nosso país: coordenadores e professores pouco preparados e forte adesão a metodologias de ensino especialmente restritivas.

A precariedade no preparo é fruto de um ciclo vicioso: quando o professor tem formação universitária, apesar de estar preparado para lecionar, frequentemente tem pouca fluência no idioma ou tem uma fluência "intermediária". Acaba trabalhando com tradução ou dando aulas no ensino fundamental e médio, onde não é exigida a proficiência oral.

As escolas de idiomas, por sua vez, prometem ensinar o aluno a falar o idioma, desenvolvendo suas competências orais, portanto não podem contratar professores com pouca fluência. Acabam contratando pessoas que moraram no exterior e, na grande maioria das vezes, aprenderam a falar o idioma na demanda prática do dia-a-dia, sem ter estudado as estruturas linguísticas e gramaticais e, claro, sem qualquer formação pedagógica. Oferece-se um treinamento de algumas horas, focando na metodologia utilizada na escola - como no exemplo acima - e sem nenhuma preocupação com questões propriamente de cunho educacional. Está aí o professor, tão despreparado quanto aquele outro, formado.

Vale lembrar, ainda, que a formação oferecida na maioria dos cursos de licenciatura é voltada à educação de crianças e jovens, mais precisamente os estudantes do ensino fundamental II e do médio. É pedagogia no sentido da palavra, como já mencionado anteriormente. Pouco se estuda tanto sobre o ensino de línguas nos anos iniciais do ensino fundamental quanto sobre o ensino de adultos. Sem pretender criticar o formato dos cursos de 
licenciatura, apenas apontamos um fato.

Portanto para aqueles professores que pretendem lecionar nos outros segmentos, como educação infantil - em escolas bilíngues, por exemplo - ou em cursos de línguas, é importante complementar essa formação, pois as didáticas e metodologias estudadas ao longo dos cursos de licenciatura acabam por não contemplar as especificidades da primeira infância ou da idade adulta. Assim, muitos professores formados caem nas malhas de um treinamento restritivo e terminam por abraçar esse ou aquele método, acreditando que aquela seria a melhor (ou única) forma de ensinar.

Em seu artigo intitulado "Derrubando paredes e construindo pontes: formação de professores de língua inglesa na atualidade", Gimenez e Cristovão (2004) examinam alguns dos obstáculos à formação dos professores de língua inglesa (as paredes) e algumas possíveis soluções (as pontes). Seu argumento inicial baseia-se no quadro geral no qual o currículo de Letras se insere. Por exemplo, quanto à avaliação dos profissionais, segundo as pesquisadoras, foram implantados o SAEB, o ENEM, o Exame Nacional de Cursos e o Exame Nacional de Certificação de Professores, mas nenhum deles contempla as línguas estrangeiras, o que as autoras consideram revelador da (pouca) importância atribuída à formação em línguas estrangeiras.

Entre os obstáculos citados está a rigidez do currículo de Letras, que não contempla a prática de ensino em diferentes campos de trabalho, nem a educação continuada, nem a formação orientada à pesquisa, limitando, assim, a possibilidade de práticas reflexivas e da consequente formação de um profissional reflexivo, com autonomia intelectual.

As mudanças (as pontes) propostas pelas autoras vêm de sua experiência nas disciplinas de Linguística Aplicada e Prática de Ensino de Língua Inglesa em uma universidade pública e consistem, entre outras coisas, numa reformulação do currículo norteada pelos tipos de competências que caracterizam a atuação profissional, para que sejam definidos os objetivos do curso; na organização e na seleção de conteúdos que contemplem temas relevantes e atuais, presentes na prática pedagógica do professor, como a educação de adultos, especialmente aqueles que voltam a estudar; a continuidade da Prática de Ensino, que fica isolada no final do curso; a interação entre os diferentes profissionais envolvidos na educação e, por fim, a inserção da pesquisa, que capacita o profissional a entender e utilizar os processos de investigação.

Mais recentemente, Carvalho (2012) fez uma análise das necessidades dos alunos de um curso de Letras. Segundo a autora, as diretrizes curriculares para a graduação em Letras (2011) determinam que os cursos tenham estruturas flexíveis, de modo que: 
- Ofereçam ao futuro profissional opções de conhecimento e atuação no mercado de trabalho;

- Criem oportunidades para o desenvolvimento de habilidades necessárias ao bom desempenho profissional;

- Priorizem a abordagem pedagógica centrada na autonomia do aluno;

- Promovam articulação entre ensino, pesquisa e extensão;

- Propiciem o exercício da autonomia universitária, ficando a cargo da Instituição as definições quanto a perfil profissional, carga horária, atividades básicas e complementares e estágio;

Esse documento oficial toca exatamente nas questões centrais levantadas por Gimenez e Cristovão (2004), e claramente tem como objetivo formar profissionais com o perfil reflexivo já mencionado. Porém, Carvalho (2012), em sua pesquisa em um curso de Letras em uma universidade privada na periferia de São Paulo, observou algumas discrepâncias entre a teoria (do documento oficial) e a prática (da universidade). Entre outras coisas, destacamos o fato de os alunos do referido curso terem a expectativa de atingir conhecimento linguístico em nível intermediário e desejarem, ao término do curso, lecionar em escolas de Ensino Fundamental, o que corrobora com nossa vivência, já exposta anteriormente. Outro dado interessante - que, aliás, também apareceu em nossa pesquisa com os alunos de escolas de idiomas - refere-se ao tipo de contato que os alunos tem com a língua inglesa fora do ambiente acadêmico. A maioria dos universitários - e dos nossos alunos de curso de idiomas - tem contato com a língua inglesa a partir de música, filmes e internet. Para todos os estudantes - e principalmente para aqueles do curso de Letras - essa situação é preocupante. Concordamos com Carvalho (2012) quando diz que há pouco contato com as fontes que gerariam educação formal, como jornais, livros e revistas.

Quanto ao caráter reflexivo do professor, Freitas, Belincanta e Corrêa (2002) salientam a grande preocupação, a partir da década de 90, com a formação do professor de língua estrangeira, assumindo uma perspectiva mais filosófica, denominada "reflexiva", "investigativa" ou "crítica". Tal orientação contrapõe-se àquela de caráter mais "prescritivo", 
relacionado ao uso das técnicas e metodologias, ou seja, o "treinamento", que, se por um lado capacita o professor a atuar em determinados contextos e reproduzir determinados métodos, por outro o limita, de várias maneiras, em sua atuação.

Um dos limites, ao nosso ver, está ilustrado na situação que abre esse capítulo: a visão de que só há uma maneira de se ensinar um determinado assunto. Freitas, Belincanta e Corrêa (2002) atribuem essa visão ao pressuposto "professor formado, produto acabado". De acordo com nossa experiência, tal ponto de vista, bastante restritivo, está presente na maioria das escolas de idiomas e não deixa de ser uma consequência da forte adesão à metodologia escolhida. $^{6}$ Ao invés de ser uma linha norteadora do trabalho docente, a metodologia é o próprio centro do trabalho. Tem-se a impressão de que é a metodologia que faz o aluno aprender (não os esforços de construção de conhecimento envolvidos no processo ensinoaprendizagem); portanto, professor bom é aquele que conhece e reproduz a metodologia o mais fielmente possível. Dentro desse modelo, segundo Freitas, Belincanta e Corrêa (2002), teoria e prática ficam dissociadas: os especialistas desenvolvem pesquisas, descobrem teorias e propõem metodologias; os professores aprendem a metodologia e a aplicam corretamente.

Essa visão parcial é, ainda, a nosso ver, responsável por disseminar outra crença: a de que existe uma metodologia melhor em detrimento de todas as outras. Para nós, a metodologia serve ao professor como um instrumento, uma linha norteadora de sua ação. Acreditamos ser a melhor metodologia aquela que vem ao encontro da realidade e das necessidades dos alunos, pois, professor, aluno e metodologia estão igualmente implicados no processo de ensino-aprendizagem. Ao optar por uma metodologia, tanto professor quanto aluno precisam ter consciência dos limites desse "instrumento" e ter um certo grau de flexibilidade e abertura para repensá-lo em sua prática, ao invés de tomar a metodologia de forma acabada e restritiva, como é geralmente o caso das escolas de idiomas. Aliás, tal visão liga-se à ideia de que, uma vez dada determinada explicação, conforme a metodologia aplicada, nenhuma dúvida surgirá. E caso surja, basta repetir a explicação para resolver o problema.

\footnotetext{
${ }^{6}$ Aqui, há uma questão de polissemia que precisa ser explicitada. Reconhecemos a importância da metodologia no sentido amplo de "estudo dos métodos" - no processo de ensino-aprendizagem e acreditamos numa metodologia adequada a um determinado contexto, apesar de julgarmos ser essa uma condição necessária, mas não suficiente. Quando falamos de metodologia no texto acima, referimo-nos especialmente ao "conjunto de procedimentos, regras e técnicas" empregados no ensino de língua estrangeira. Nossa crítica, portanto, relacionase aos "conjunto de procedimentos, regras e técnicas" que limitam de modo considerável a atuação do professor.
} 
A seguir, apresentaremos, então, alguns aspectos da educação voltada para adultos que compõem os sujeitos dessa pesquisa - de acordo com a perspectiva do educador americano Malcolm Knowles. Trataremos também do próprio objeto de conhecimento - a língua inglesa - ou seja, como é visto e abordado o ensino de idiomas nas escolas, no tocante ao encontro entre língua materna e língua estrangeira.

\subsection{Principais características dos aprendizes adultos}

Segundo Malcolm Shepherd Knowles (1970), o termo andragogia foi cunhado por educadores europeus, especialistas em adultos, para melhor definir a especificidade dessa educação, mas foi o próprio educador americano um dos primeiros a empregar o termo para diferenciar o ensino voltado às crianças daquele voltado aos adultos. Knowles (1970) define andragogia como "a arte e a ciência de ajudar os adultos" (p. 43). Porém, o educador não deixa de salientar que a andragogia não é o oposto da pedagogia, mas complementar a ela. Trata-se de outro modelo, que pode oferecer diferentes alternativas e soluções para os processos envolvidos no ensinar e no aprender.

Especialmente após a Segunda Guerra, quando a educação de adultos passa a ser sistemática, os professores começaram a enfrentar maiores problemas com o modelo pedagógico, cujas origens foram citadas na apresentação desse trabalho. Devido às mudanças sociais decorrentes da industrialização, da crescente urbanização e do rápido progresso tecnológico, a instrução de adultos provenientes da classe operária fez-se necessária. A educação formal, antes reservada apenas às elites, passa a ser, então, de grande importância nesse cenário de transformações.

Vogt e Alves (2005), ao fazer uma revisão teórica sobre a educação de adultos, começam pela importância e pelos objetivos da educação: ela favorece não só o desenvolvimento socioeconômico de um país e de uma sociedade, mas também o desenvolvimento pessoal, pela busca da superação e da auto-realização e pela busca do preparo para responder às demandas pessoais e sociais. É imperativo, portanto, conhecer o ser humano em sua fase adulta, com suas peculiaridades:

"um ser em desenvolvimento histórico que, diante da herança de sua infância, da sua passagem pela adolescência e a caminho do envelhecimento, continua o processo de individualização de seu ser e de sua personalidade" (LUDOJOSKI, 1972, APUD Vogt e Alves) 
Um dos principais problemas do modelo pedagógico, apontado por Knowles (1970) relacionava-se à premissa de a educação significar, em grande parte, transmissão de conhecimentos "para a vida toda", quer dizer, conhecimentos passíveis de aplicação por toda a vida de um sujeito. O autor cita, então, um filósofo chamado Alfred North Whitehead, que chama nossa atenção para um fato importante: a modernidade e suas rápidas mudanças culturais, sociais, políticas e tecnológicas está interferindo na concepção de conhecimentos "para a vida toda", transmitidos de geração em geração, pois essas rápidas mudanças passaram acontecer durante o período de vida das pessoas, ou seja, em espaços de tempo cada vez mais curtos, fazendo-se necessário pensar numa educação em processo contínuo.

A compreensão do homem como um "ser em constante desenvolvimento" é, portanto, um avanço em relação à ideia de estagnação na fase adulta. Para Piaget, cuja teoria embasa nosso trabalho, a fase adulta faz parte do período operatório formal ou período das operações formais (a partir de 12 anos, em média), que será descrito mais adiante, na seção 11.1.

No período das operações formais, o pensamento eleva-se à segunda potência, ou seja, ampliam-se as capacidades adquiridas no estágio anterior, operatório concreto (entre 7 e 12 anos, em média), início do pensamento lógico, no qual a criança consegue relacionar diferentes aspectos e abstrair dados da realidade, porém, sendo ainda muito dependente do mundo concreto (aqui, o possível é igual ao real).

No estágio das operações formais, a criança (e o adulto) é capaz de pensar sobre seu pensamento. Como a representação agora permite a abstração total, desprende-se da realidade concreta, sendo capaz de tecer hipóteses e fazer deduções, de pensar criticamente sobre sistemas sociais, códigos e condutas, além de discutir e construir seus próprios valores morais e criar teorias. É o período no qual se começa a elaborar programas de vida e fazer planos e projeções futuras. Para esse pensamento, o possível é maior que o real. Ao chegar neste estágio, o sujeito atinge sua forma final de equilíbrio, o que não quer dizer que seu desenvolvimento termine aí. Foi o último patamar de inteligência descrito por Piaget porque entendeu ser esse o tipo de inteligência mais potente no desenvolvimento humano, mas não o término desse desenvolvimento.

Em seu livro "O ciclo vital", Bee (1997) descreve as características físicas, emocionais, cognitivas e sociais ao longo da fase adulta. Para complementar nossa discussão, selecionamos e apresentaremos algumas das características cognitivas e sociais, que consideramos relevantes para nosso estudo.

Segundo a autora, as definições "início da vida adulta", "meia-idade" e "velhice" são 
arbitrárias e podem diferir de um subgrupo para outro, de acordo com a cultura e com o tempo histórico. Por convenção, a maioria dos pesquisadores faz a seguinte divisão:

- 20 - 40 (jovem adulto)

- 40 - 65 (adulto intermediário/ meia-idade)

- 65 em diante (idoso - coincide com a aposentadoria na maioria dos países industrializados)

\section{a) Jovem adulto}

Características cognitivas: Alguns teóricos defendem que a vida adulta ainda traz uma reorganização da estrutura de pensamento, uma espécie de pensamento pós-formal. As exigências da vida adulta forçariam duas espécies de mudanças nessa estrutura (de acordo com Labouvie-Vief):

1) mudanças para uma forma mais "pragmática" de pensamento, com ênfase na solução de problemas e desafios.

2) abandono de um modo analítico de pensar, focado nos fatos e nas respostas claras, em favor de um maneira de pensar centrada na imaginação e na metáfora, aberta a incertezas e paradoxos.

Características sociais / psicossociais: Na primeira fase da vida adulta, cada um assume seu lugar na sociedade. Isso significa aquisição, aprendizado e desempenho de três papéis fundamentais: profissional, conjugal e parental. O processo inicia-se, geralmente, com a saída de casa, o que envolve separação física e emocional dos pais, além do exercício da autonomia e da independência. $\mathrm{O}$ adulto jovem cria um aglomerado de relações (família, amigos, parceiro) e suas amizades tendem a ser maiores em quantidade. A maternidade/paternidade traz alegria e, ao mesmo tempo, o desafio de um novo papel a ser aprendido. $\mathrm{O}$ trabalho traz sustentação econômica, além de satisfação. Entre as mulheres, em geral as que trabalham fora de casa mostram-se mais satisfeitas e mais saudáveis. A escolha do trabalho é influenciada por uma série de fatores: família, formação/habilidades, sexo e personalidade. 


\section{b) Adulto intermediário / Meia-idade}

Características cognitivas: As habilidades cognitivas são geralmente mantidas em bom estado, a não ser por aquelas não-exercitadas ou no caso das que requerem maior velocidade. Há certa perda de memória, embora ainda pequena. A produtividade criativa parece permanecer elevada, pelo menos no caso de adultos que tenham trabalhos desafiadores. A importância do exercício é um tema permanente na pesquisa sobre o funcionamento físico e cognitivo na vida adulta intermediária. Adultos que mantém níveis elevados de exercício, tanto físico quanto mental, parecem continuar com suas habilidades em melhor estado. Adultos da classe média operária evidenciaram níveis piores de manutenção ou maior declínio físico e mental.

Características sociais / psicossociais: Os anos da meia-idade tendem a ser mais felizes e menos estressantes se comparados ao início da vida adulta, pois os estudiosos verificam uma maior satisfação conjugal e interações familiares mais significativas. Adultos dessa fase oferecem mais assistência e influenciam mais tanto quem os antecede quanto quem os procede. Pais na meia-idade reagem melhor à saída dos filhos de casa. A maioria dos adultos torna-se avô nessa idade. As amizades parecem menos numerosas, mas não há evidências de que sejam menos íntimas. A maioria trabalha, embora a centralização do papel profissional pareça um tanto menor e a quantidade de horas diminua.

\section{c) Idoso}

Características físicas / cognitivas: Há mudanças no cérebro, associadas ao envelhecimento, principalmente perda de densidade dendrítica dos neurônios, acarretando o efeito de retardar o tempo de reação, em quase todas as tarefas. Além disso, há redução de peso no cérebro, perda de massa cinzenta e desaceleração das sinapses. Há perda de audição para sons mais altos, perda de capacidade de discriminar palavras e uma maior dificuldade para ouvir em ambientes ruidosos. Homens estão mais propensos às perdas auditivas que mulheres, pois mais homens trabalham em ambientes com alto nível de ruído. Há, também, um tilintar persistente nos ouvidos que aumenta com a idade (tinnitus). A "presbicose" resulta de uma degeneração gradativa de virtualmente todas as partes do sistema auditivo. Adultos mais velhos secretam mais cera no ouvido, o que pode bloquear o canal auditivo, os ossos do ouvido médio calcificam-se e tornam-se menos elásticos, as membranas da cóclea do ouvido interno ficam 
menos flexíveis e menos reagentes e ocorrem degenerações das vias nervosas para o cérebro. Há perdas também no paladar e no olfato. Perdas olfativas são, no entanto, muito maiores e mais definidas. Isso acarreta a redução de vários prazeres da vida. Padrões de sono mudam com a idade. Adultos com mais de 65 anos costumam acordar com maior freqüência à noite. Estão mais propensos a ir para a cama mais cedo e levantar mais cedo, além de cochilar durante o dia. As demências atingem mais ou menos 15\% dos adultos com mais de 85 anos, sendo a doença de Alzheimer a mais comum entre elas. Após os 70 anos há decréscimo de todas as funções cognitivas. Isso se reflete na maioria dos testes de memória. A solução de problemas mostra um padrão similar. Adultos mais velhos mostram-se menos capazes de encontrar soluções variadas. Apesar de todas essas perdas, mesmo na fase final da vida adulta, os adultos possuem a capacidade de melhorar o desempenho em qualquer tarefa cognitiva, mediante exercício. Há muitas diferenças individuais quanto ao ritmo e momento de certas mudanças, pois são afetados pela hereditariedade, pela saúde geral e pelos hábitos de saúde anteriores e atuais, especialmente quanto a exercícios físicos e mentais, e pela disponibilidade de apoio social adequado. Habilidades não utilizadas com freqüência declinam mais rapidamente. No entanto, o efeito mais perceptível no comportamento diário é a desaceleração das reações.

Características sociais / psicossociais: Permanência de taxa elevada de envolvimento social. Normalmente, só se observa declínio no envolvimento social daqueles cujas incapacitações físicas tornam a mobilidade mais difícil. O grau de envolvimento social, em geral, está relacionado à satisfação da vida. As relações conjugais são, em média, entre pessoas com elevada satisfação conjugal, com forte lealdade e afeto mútuo. Idosos casados tendem a ser um pouco mais saudáveis e mais satisfeitos que os solteiros. A quantidade de filhos parece não ter conexão com o nível geral de satisfação. As relações com parentes podem tornar-se mais importantes. O grau de contato com amigos está relacionado ao grau geral de satisfação. As mulheres continuam a ter amplas redes sociais. Os homens confiam mais em suas esposas. As mulheres confiam nos filhos e amigos. A aposentadoria parece não ser uma mudança estressante para a maioria.

Combinando os dados apresentados acima com nosso trabalho de pesquisa e nossa experiência docente, percebemos a possibilidade de identificar alguns "perfis" de aprendizes adultos. Por exemplo, a maioria do público da escola de idiomas onde foram colhidas as entrevistas está na primeira faixa - adulto jovem. É o público universitário, em início de 
carreira, fortemente engajado no aprendizado de uma profissão e procurando aprender um idioma para, na maioria das vezes, complementar o currículo. Estão numa espécie de fase de transição entre a dependência - financeira e afetiva - parental e a autonomia e, por isso, geralmente estão testando seus limites (e os do professor). Na ânsia de assumir seu lugar na sociedade, costumam ser mais incisivos em suas decisões e acumular muitas tarefas que acabam por não terminar (por exemplo, o curso de inglês).

Por outro lado, uma parcela que vem crescendo nos últimos anos é a de aprendizes na terceira faixa - adulto idoso. Esses, já aposentados, sem a pressão de competir por um "lugar ao sol", justificam seu interesse no estudo como forma de manter a mente em funcionamento e, consequentemente, ter uma melhor qualidade de vida. São naturalmente mais lentos, mas muito propensos à socialização.

Ocorre que, muitas vezes, o professor se depara com esses diferentes perfis numa mesma sala de aula. Nesses casos, uma linha de trabalho mais flexível seria o ideal para dar conta das demandas específicas de cada grupo etário, de preferência com objetivos definidos com a participação de todos, e não por imposição da metodologia.

Finalmente, gostaríamos de lembrar que conhecer as características próprias dos adultos de modo geral e de cada fase da idade adulta é importante para traçarmos planos de ação em nosso trabalho docente, não simplesmente para usar essas diferenças como "rótulos", pois, dessa maneira, cairíamos num apriorismo inútil.

Voltando a Knowles (1970), há ainda uma segunda questão apontada pelo autor, essencial para nosso trabalho, e diz respeito às características dos adultos, agora especificamente no papel de aprendizes. Segundo o autor, nós, educadores, deveríamos levar em consideração quatro premissas básicas sobre as características dos aprendizes adultos:

1) prontificam-se a aprender algo quando percebem a necessidade daquilo em sua prática na vida real;

2) acumulam, durante a vida, experiências que são fonte de conhecimento para eles mesmos e para os outros, portanto atribuem mais significado aos aprendizados ganhados através da prática do que aos adquiridos passivamente e preferem trabalhar a partir de discussões, solução de problemas e exercícios de simulação;

3) são mais independentes e têm necessidade de manter essa orientação; 
4) acreditam na educação como "potencializador" do desenvolvimento e querem ser capazes de aplicar imediatamente qualquer conhecimento adquirido - por isso as motivações internas (intrínsecas) são as mais potentes.

Dessas quatro, a que mais nos chama a atenção é a última, no que diz respeito à aplicação imediata do conhecimento. Como os cursos de idiomas prometem fluência oral, percebemos muita angústia por parte dos alunos quanto a isso.

Sabendo dessa necessidade de aplicação rápida do conteúdo aprendido, sobretudo em relação à habilidade da fala, cabe ao professor, por um lado, pensar estratégias facilitadoras desse uso, e, por outro, conscientizar os alunos de que eles próprios têm um papel ativoreflexivo na construção desse conhecimento.

Por ser uma habilidade de produção, falar demanda mais esforço em sua construção, pois requer do sujeito uma atitude ativa e bastante reflexiva, além de depender da interação com outro sujeito. Pode parecer óbvio, mas, na prática de sala de aula, nem sempre há essa consciência, seja por parte do aluno ou do professor: os alunos frequentemente se queixam de "travar" na hora de falar, mesmo quando entendem o interlocutor e sabem o que querem dizer, e os professores geralmente atribuem isso à pouca dedicação do aluno ao estudo gramatical. A verdadeira questão está centrada no fato de que falar envolve muitas dimensões da língua: a estrutura, a pronúncia, a entonação, o vocabulário, enfim. Planejar e organizar tudo isso é uma atividade bastante complexa. Daí a importância da consciência (de ambos) nesse processo.

Olhando a questão de outra maneira, pode-se pensar no tipo de aproximação (ou afastamento) que se faz entre língua estrangeira e língua materna. Mesmo os professores, inclusive os mais preparados, intrigam-se com o fato de um aluno ter dificuldade em aprender um segundo idioma. Isso evidencia uma aproximação das condições de aprendizagem das duas línguas - assunto do qual trataremos mais adiante, quanto às diferenças na aquisição. Tal aproximação deve-se, em parte, ao próprio caráter do objeto de conhecimento: o homem é dotado da habilidade de falar. "Esse estar-se já aí da primeira língua é um dado iniludível”, afirma Revuz (1998:215). Portanto, é natural que ele fale! Sendo assim, cria-se uma expectativa em torno da produção oral de ambas as partes, professor e aluno, o que pode gerar dúvidas, incertezas e angústias (lembrando que para Piaget, a afetividade é energética, portanto não necessariamente atrapalha o aprendizado, mas "dá o tom").

Em se tratando de língua materna, temos realmente a sensação de já nascermos falando, reforçando a ideia de que as línguas "estão aî" e podem ser superpostas, fazendo parecer que a segunda língua pode ser estruturada a partir da primeira. Por isso - além da 
própria característica dos adultos, já mencionada, de querer colocar o conhecimento aprendido imediatamente em uso - os alunos demonstram muita insatisfação por não conseguirem se expressar com certa fluência, mesmo no início do curso.

No entanto, por mais que os objetos sejam de mesma natureza, são diversos em sua estrutura, em sua organização. Por isso temos que "estudar" a segunda língua, do mesmo modo como estudamos qualquer outro assunto "e o encontro com uma outra língua aparece efetivamente como uma experiência totalmente nova" (Revuz, 1998:215). E aqui começa o "afastamento". Para ilustrá-lo, temos as respostas de alguns alunos participantes de nossa entrevista. Perguntados se "estudar inglês o fez se aproximar mais de sua língua nativa, o português", quatro entre vinte entrevistados respondeu não fazer qualquer relação entre as duas línguas (os dados serão analisados com mais profundidade, na segunda parte desta dissertação), evidenciando uma ruptura que pode significar um menor nível de consciência quanto ao que é geral às línguas, o que faz parte da natureza ou da essência delas e, nesse caso, pode ser generalizável.

A nosso ver, é importante observar esse confronto entre as línguas, esses movimentos de aproximação e afastamento entre elas, evitando deixar os aprendizes caírem na ilusão dos extremos, da total separação ou identificação.

Esse confronto entre a primeira e a segunda língua nunca é anódino para o sujeito e para a diversidade de estratégias de aprendizagem (ou de não aprendizagem) de uma segunda língua, que se pode observar quando se ensina uma língua e se explica, sem dúvida, em grande parte pelas modalidades desse confronto. (Revuz, 1998:215)

O mais relevante para o ensino de um idioma não é, portanto, simplesmente uma metodologia em si, especialmente se for muito restritiva, mas os aspectos envolvidos na “disputa" entre as línguas, como os afastamentos e aproximações, as explorações fonéticas, para as quais é preciso permitir-se a liberdade de redescobrir o próprio corpo, além do fato de que as palavras não se correspondem sempre, revestindo-se, por vezes, de novos significados, com nova carga afetiva: "...aprender a falar uma língua estrangeira é, efetivamente, utilizar uma língua estranha na qual as palavras são apenas muito parcialmente 'contaminadas' pelos valores da língua materna na medida, precisamente em que não há correspondência termo a termo." (Revuz,1998:224)

$\mathrm{Na}$ verdade, a possibilidade de aceitar as singularidades de cada língua é que nos faz atingir um nível mais avançado de compreensão. É isso que nos faz ter a sensação de que tal ou qual termo de uma determinada língua nos parece mais adequado ou mesmo mais "bonito" 
para se usar em uma situação, ou até a sensação de que outra língua, que não a nossa, possui um termo ou uma expressão mais precisa para designar isto ou aquilo.

Em seguida, exploraremos as motivação para o aprendizado - intrínsecas, extrínsecas - e qual consideramos mais adequada no contexto do aprendizado de línguas. Tomaremos como base principalmente os estudos de Ryan e Deci, porém mencionaremos alguns importantes estudos brasileiros também.

\subsection{A questão da motivação}

A maioria das escolas de idiomas tende a dar alguma importância à dimensão afetiva, porém, a nosso ver, sem muita eficácia.

Motivar o aluno é tarefa de todo o professor de idiomas, está em todos os manuais e é parte de todo treinamento. O que se entende por motivar, no entanto, está mais para divertir o aluno. Nas tais "aulas show", o professor é um verdadeiro artista, canta, dança, toca instrumentos, motiva. Motiva?

Ryan e Deci (2000) definem estar "motivado" como estar "movido a fazer a algo", estar "energizado" em relação a um fim. Ao contrário, quem não sente nenhuma inspiração ou não tem nenhum ímpeto de fazer algo está "amotivado". Ryan e Deci (2000), porém, não entendem motivação como um fenômeno unitário, senão seria apenas uma questão de quantidade. A motivação pode variar não só em nível (o quanto de motivação), mas também em orientação (quais atitudes e objetivos levam à ação, ou seja, quais são os motivos da ação). Por exemplo, um aluno pode estar altamente motivado a realizar uma tarefa por curiosidade ou apenas para receber aprovação dos professores ou dos pais, uma pessoa pode estar motivada a aprender uma nova habilidade, como uma língua estrangeira, porque entende e acredita no potencial de aplicação desse novo conhecimento em sua vida ou para incrementar seu currículo. A quantidade de motivação pode ser alta em todas as situações descritas, porém sua natureza, sua "origem" é diferente em cada um dos cenários apresentados. Os pesquisadores, então, fazem uma distinção dos tipos de motivação de acordo com os objetivos e razões que levam um sujeito a agir. São as motivações intrínsecas e extrínsecas, das quais nos ocuparemos mais adiante.

Para Ryan e Deci (2000) a motivação funciona como um regulador do comportamento, na medida em que os comportamentos diferem principalmente no quanto sua regulação provém de uma escolha livre ou da pressão de alguma força externa ou 
intrapsíquica. O processo regulatório subjacente é, portanto, a escolha.

Interessante notar que os pesquisadores contrapõem "escolhas livres" a "forças externas ou intrapsíquicas", levando-nos a pensar numa possível ligação entre os níveis de consciência que o sujeito tem em relação às suas escolhas e sua capacidade de controlar e justificar tais escolhas, colocando-as em escalas hierárquicas de valores.

O interesse, para Piaget (1954) é a energética que regula a interação com o objeto de conhecimento. Se não há interesse, não há motivos para se resolver um problema. Ou melhor, se não há interesse, o problema nem se coloca. Consequentemente, o sujeito não produz conhecimento, na medida em que, para Piaget, inteligência é adaptação e está orientada ao equilíbrio do sujeito em relação às demandas do ambiente.

De acordo com tal ponto de vista, se afirmarmos que alguém fez alguma coisa porque foi obrigado, podemos, ainda assim, afirmar também que havia interesse envolvido na execução da ação, mesmo que um interesse fortemente "extrínseco" (por obrigação), pois, tal pressão do ambiente moveu o sujeito a adaptar-se a essas demandas e, para isso, precisou empregar certa quantidade de combustível (interesse).

$\mathrm{Na}$ medida em que interesse é o combustível, a energética para a resolução dos problemas (e para a construção de conhecimento), o valor é seu aspecto qualitativo. No exemplo acima, em que se faz algo por obrigação, a qualidade da energética dispendida para a solução do problema está fortemente rebaixada. Ainda que tenha sido resolvido de forma adequada, o sujeito não usou seu combustível de melhor qualidade. Esse combustível "de boa qualidade" fica guardado para os objetos que realmente o interessam, devidamente organizados num sistema de valores pessoal.

No cenário da obrigatoriedade de se aprender a língua inglesa, nosso questionamento central é quanto à qualidade do combustível empregado pelos alunos, ou seja: “Qual o valor de seu interesse na língua inglesa em face à tentativa de se adaptar às exigências do ambiente (na maioria das vezes, o mercado de trabalho)?" Será que um "combustível de boa qualidade" o ajudará, por exemplo, a ter mais sucesso em seu relacionamento com o idioma (ainda que não no sentido acadêmico de "tirar boas notas") e a traçar metas? É o que pretendemos estudar - e talvez responder - na segunda parte dessa dissertação.

Retomando nossa discussão inicial, em seu artigo intitulado "Motivação no ensino superior: metas de realização e estratégias de aprendizagem" Cardoso e Bzuneck (2004) sustentam que, a partir da década de 90 , os pesquisadores chegaram a quatro possíveis metas de realização: 
Aprender (ou domínio, ou tarefa): diz respeito à busca de novos conhecimentos. $\mathrm{O}$ aluno acredita em seu esforço pessoal como determinante para seu bom desempenho e, em geral, não desanima em face dos desafios. Preocupa-se mais com o processo de aprender do que com o resultado;

Ego-aproximação (ou performance-aproximação): o aluno tem por objetivo um alto desempenho acadêmico. Preocupa-se com o resultado;

Ego-evitação: seu principal objetivo é não parecer incapaz diante de seus pares;

Evitação do trabalho (ou alienação acadêmica): o aluno está orientado para o sucesso acadêmico, desde que não precise de muito esforço. Não se preocupa em parecer mais ou menos inteligente que ou outros.

As pesquisas têm relevado que os estudantes podem estar orientados para mais de uma meta, simultaneamente. Além disso, têm demonstrado uma conexão entre metas de realização e estratégias de aprendizagem. Dito de outra forma, a qualidade do esforço empregado (a estratégia) está relacionada à meta de realização. Têm-se verificado, também, que a escolha da(s) meta(s) de realização é fortemente influenciada pelas percepções nas ênfases dadas por seus professores nos conteúdos e numa aprendizagem significativa.

Em "Motivação para aprender: relação com o desempenho de estudantes", Zenorini, Santos e Monteiro (2011) destacam a complexidade do assunto devido às muitas variáveis envolvidas na motivação do aluno (ambiente de sala de aula, ações do professor, questões emocionais, falta de comprometimento do aluno, estratégias de aprendizagem inadequadas, etc). As autoras reiteram que a Teoria de Metas de Realização vêm sendo utilizada para explicar a motivação para aprender focando no aspecto qualitativo do envolvimento de um aluno em seu processo de aprendizagem. Estudos baseados nessa teoria têm procurado compreender a maneira como os alunos pensam sobre si mesmos, sobre suas tarefas e sobre seu próprio desempenho. De acordo com as autoras, Ames (1992) definiu as metas de realização como "um conjunto de pensamentos, crenças, propósitos e emoções que traduzem as expectativas dos alunos em relação a determinadas tarefas as quais deverão executar". As autoras ressaltam ainda que, de acordo com Bzuneck (2004), apesar da semelhança entre a "meta aprender" e a "motivação intrínseca", estamos diante de pressupostos diferentes. Enquanto a motivação intrínseca caracteriza-se pela "escolha autodeterminada da ação", 
portanto sem necessário comprometimento externo, a meta aprender implica o ambiente e o professor como determinantes no processo. As percepções do aluno sobre as características do ambiente, as ações do professor, as avaliações e os feedbacks recebidos influenciam seu desenvolvimento de metas.

Em, "O Estilo Motivacional do Professor e a Motivação Intrínseca dos Estudantes: Uma Perspectiva da Teoria da Autodeterminação", Guimarães e Boruchovitch (2004) explicam que a Teoria da Autodeterminação de Deci e colaboradores (Deci \& Ryan, 1985; Ryan, Connell \& Deci, 1985) tinha por objetivo compreender os elementos da motivação intrínseca e extrínseca e quais os fatores ligados ao seu desenvolvimento. Contrapondo-se às ideias oriundas das abordagens comportamentais, como satisfação das necessidades fisiológicas, busca por eficácia e por recompensa como sendo os disparadores das atividades humanas, Deci e colaboradores consideraram as tendências evolutivas, as necessidades psicológicas inatas e as condições contextuais em sua teoria, sustentando que, em comportamentos intrinsecamente motivados, a recompensa seria a própria realização da atividade.

Não nos detendo muito em detalhar a referida teoria, mas colocando em relevo aquilo que para nós é importante nesse momento, gostaríamos de destacar a ligação que Guimarães e Boruchovitch (2004) fizeram entre o estilo motivacional do professor e a motivação intrínseca. Segundo a Teoria da Autodeterminação, há três necessidades psicológicas inatas, subjacentes à motivação intrínseca: a necessidade de autonomia, a necessidade de competência e a necessidade de estabelecer vínculos. Uma situação de aprendizagem, especialmente em ambiente de sala de aula, precisa oferecer condições de satisfação de tais necessidades e o professor é um dos atores principais nesse processo. Seu estilo motivacional é considerado uma característica relacionada à sua personalidade (há os mais controladores, os mais autoritários, os mais flexíveis, etc.), porém permeável a fatores sócio-contextuais, como o número de alunos em sala, sua experiência, sua idade, suas concepções ideológicas, etc. As pesquisas apontam a importância do estilo motivacional do professor na orientação motivacional do aluno e indicam vantagens do estilo motivacional "promotor de autonomia" (em oposição ao controlador).

Em suma, examinando os dados dos estudos apresentados, podemos dizer que as motivações - agora usando o termo em sentido geral - consideradas mais benéficas possuem, em todos os casos, um componente ou característica pessoal, subjetiva: 
1) Para Piaget o interesse parte do sujeito em face à sua necessidade de adaptação ao ambiente para consequente retomada do equilíbrio;

2) A meta aprender parte do sujeito no seu contexto escolar e é retroalimentada por suas percepções pessoais quanto às características do ambiente e do professor;

3) A motivação intrínseca deriva da autodeterminação do sujeito e depende da satisfação de três necessidades psíquicas (necessidade de autonomia, necessidade de competência e necessidade de estabelecer vínculos).

Acreditamos que tais constatações serão, portanto, primordiais na evolução de nosso presente trabalho.

Voltando a observar as escolas de idiomas, gostaríamos de fazer uma derradeira consideração. Entre as estratégias entendidas como motivação está deixar os alunos "à vontade", cada um organizando o tempo e as tarefas como bem lhe aprouver, sem muitas cobranças, sem muito "sofrimento". E mais, as aulas "tradicionais" ou "expositivas" são desencorajadas, pois - acredita-se - o aluno vai aprender com sua própria experiência, no seu próprio tempo. Talvez essa seja uma tentativa de encorajar a autonomia dos alunos acabamos de constatar que a necessidade de autonomia é um dos requisitos para a motivação intrínseca - por outro lado, sabemos que algumas coisas precisam, sim, ser explicitadas, como a cultura, as convenções sociais e os conhecimentos científicos construídos pelo homem, por exemplo. Além disso, promover a autonomia não é deixar "cada um por si", ao contrário, autonomia implica envolvimento no grupo e com o grupo, participando das tomadas de decisão e das propostas de solução. É preciso ser reflexivo para ser autônomo ${ }^{7}$.

Contraditoriamente, mesmo em cursos com as tais metodologias "dinâmicas", "inovadoras", as aulas ainda são centradas no professor e a passividade dos alunos chega a ser preocupante, especialmente no caso dos adultos, que esperam encontrar no professor todas as respostas, mesmo aquelas que ele pode procurar por si mesmo.

Em primeiro lugar, não pode haver aprendizado se o sujeito não se apropria do conhecimento, não se modifica para, então, modificar o conhecimento, adaptando-o à sua necessidade. É imprescindível sair da zona de conforto, ficar vulnerável, desequilibrar-se e

\footnotetext{
${ }^{7}$ Nossa observação quanto à autonomia dos aprendizes refere-se, mais uma vez, exclusivamente a determinadas práticas comuns em escolas de idiomas, conforme mencionado acima, quando autonomia é erroneamente confundida com motivação. Na aprendizagem de modo geral, não negamos a relevância da autonomia no processo de ensino-aprendizagem. Tudo depende dos conteúdos e do contexto da aprendizagem.
} 
passar pela experiência modificadora!

Aprendizagem, por consistir em um processo de mudança duradoura, produzido pela experiência, tem um forte caráter adaptativo, em virtude da vantagem conferida aos organismos que se modificaram em resposta ao experienciado no ambiente. (Leme, 2011)

Em segundo lugar, muitos estudantes de idiomas tendem a fazer maior uso de estratégias de memorização, (tradução termo a termo, por exemplo, que lhes traz maior sensação de segurança) ou seja, estruturas cognitivas menos elaboradas, limitando-os quanto ao uso da língua. Essas estratégias podem ser suficientes para uma aplicação "instrumental" do idioma (leituras simples e comunicação básica, em geral, automatizada), mas é preciso um trabalho cognitivo mais elaborado (como planejar, antecipar, por ex.) para ser capaz de se "falar" uma língua com autonomia.

Por tudo isso é necessário melhor preparo dos professores não só quanto às questões pedagógicas, mas também quanto ao real significado de "motivação" e "motivar". Dessa maneira, podemos ajudar nossos alunos, conhecê-los e reconhecê-los como aprendizes capazes e orientá-los em suas estratégias de aprendizado e em seus momentos de dificuldade.

A próxima seção será dedicada a examinar alguns aspectos referentes às semelhanças e diferenças na aquisição da língua materna e da estrangeira. 


\section{Aquisição de língua materna versus aquisição de L2: alguns aspectos e teorias}

"A língua estrangeira, objeto de saber, objeto de uma aprendizagem raciocinada é, ao mesmo tempo, próxima e radicalmente heterogênea em relação à primeira língua." A frase de Revuz (1998:215) resume os sentimentos de grande parte daqueles que se propõem a aprender um novo idioma. Duas línguas, ao mesmo tempo tão próximas em sua essência comunicativa e às vezes tão distantes em sua estrutura, a segunda língua é objeto de uma "aprendizagem raciocinada", mesmo quando os primeiros contatos se fazem pela modalidade oral. O fato é que a segunda língua vai erguer-se sobre alicerces pré-existentes (em geral, os da língua materna, porém depende da idade da aquisição) e, por isso, tais bases não podem ser ignoradas.

Desde o primeiro contato do aprendiz com uma outra língua existem várias interferências provenientes de sua experiência com sua língua materna. Essas interferências variam de intensidade - o quanto cada sujeito consegue "equilibrar" a influência de uma língua na outra - e de níveis, não podendo ser simplesmente ignoradas. Ao contrário, são um ótimo motivo para a reflexão. Vejamos algumas delas:

- Interferência ao nível fonológico: $O$ aprendiz vai se deparar com sons inexistentes em sua própria língua e deverá, portanto, re-descobrir e re-educar seu aparelho fonador. Essa experiência não é sempre agradável. Uma sensação de angústia pode surgir como decorrência da dificuldade de compreensão e/ou de articulação desses sons: "Esse trabalho de apropriação da boca não é 'natural' a julgar pelos risos explosivos e bloqueios que suscita. Alguns se negam energicamente a isso. É tão difícil para eles sair dos automatismos fonatórios de sua língua materna que não conseguem repetir mesmo as sequências mais simples." (Revuz, 1998: 221). Muitos especialistas acreditam que aí está uma das maiores dificuldades dos aprendizes, especialmente dos adultos, pois, não tendo modelos desses novos sons em seu repertório linguístico, eles teriam que "fabricá-los", física e conscientemente. O professor, aqui, desempenha um papel fundamental no auxílio à "fabricação" - inclusive explicando como fazê-lo - e no manejo dos eventuais desconfortos ao longo do processo.

- Interferências ao nível grafo-fonêmico: $O$ aprendiz precisará reconstruir seu sistema grafo-fonêmico, gerando novas associações entre letras e sons, bem 
como novas hipóteses de escrita ortográfica, com base nas características da nova língua: "A relação entre ortografia e fonologia varia entre as línguas alfabéticas. Consequentemente, aprender a ler uma segunda língua alfabética que usa as mesmas letras da primeira, aumenta a possibilidade de associações fonológicas para as mesmas unidades ortográficas." ${ }^{8}$ (Nosarti, Mechelli, Green \& Price, 2010:315. Tradução nossa). Em consequência disso, nem sempre apenas a associação grafo-fonêmica será suficiente para a decodificação: "Como resultado da inconsistência grafo-fonêmica do inglês, ler nessa língua demanda uma mediação mais lexical ou semântica. Dito de outra forma, conhecer a palavra e seu significado ajuda a resolver conflitos de pronúncia." ${ }^{9}$ (Nosarti, Mechelli, Green \& Price, 2010:315. Tradução nossa).

- Interferências ao nível estrutural (morfossintático e textual): O estudante tenta colocar a nova língua dentro de uma estrutura já conhecida, ou seja, usa sua própria língua como guia para a construção da segunda. Por esse motivo algumas metodologias excluem o uso da língua materna, para evitar a tentação de traduzir palavra por palavra. No entanto, em nossa experiência, a proibição total do uso da língua materna em sala de aula acaba por criar uma sensação de desconforto e insegurança nos alunos que, no final das contas, acabam traduzindo, até pela variedade de ferramentas disponíveis com esse fim. E pior traduzem absolutamente tudo, na maior parte das vezes sem contextualização, produzindo associações fechadas, por exemplo, dando a cada palavra uma única significação. Muito melhor seria permitir a tradução e orientá-los quando e como fazê-la: quando necessário e com reflexão (preferindo o uso de dicionários a sites de tradução).

- Interferências ao nível sócio cultural: Ligadas às questões semânticas e pragmáticas, (in)capacidade de construção de novos significados, conceitos e

\footnotetext{
${ }^{8}$ The relationship between orthography (spelling) and phonology (speech sounds) varies across alphabetic languages. Consequently, learning to read a second alphabetic language, that uses the same letters as the first, increases the phonological associations that can be linked to the same orthographic units.

${ }^{9}$ As a result of spelling-to-sound inconsistency in English, reading requires more lexical or semantic mediation (Paulesu et al. 2000). Put another way, knowledge of a word and its meaning helps to resolve conflicting pronunciations (Plaut et al. 1996).
} 
"pontos de vista", e, principalmente, aceitação desses. Questão primordial para nossa discussão: a construção de um novo conhecimento linguístico, a partir da (re)construção de um sistema pessoal de valores, ligados aos interesses daquele que aprende, ou seja, ligados à afetividade. Quer dizer, o aprendizado de uma língua estrangeira implica, de certa forma, a aceitação de uma "multiplicidade" humana - da possibilidade de ser o mesmo, sendo diferente, de aprender novas formas de expressar o mesmo, ou de descobrir (e, principalmente, aceitar) que às vezes não se pode dizer em outra língua o que se diz na sua.

Nem todo mundo está pronto para essa experiência. Ela representa para alguns aprendizes um perigo que eles evitam... evitando aprender a língua. Alguns porão em funcionamento a estratégia da peneira: eles aprendem mas não retêm quase nada ou muito pouco. Outros adotarão a estratégia do papagaio: sabem de memória frases-tipo, conseguem mais ou menos "exprimir-se" em áreas bem delimitadas (vocabulário técnico, por exemplo), mas não se permitem nenhuma autonomia na compreensão ou na expressão. Para outros será a estratégia do caos: a língua estrangeira ficará eternamente um acúmulo de termos não organizado por regra alguma, o que os condena a um galimatias pseudo-infantil mais ou menos eficaz. Outros finalmente evitam toda distância em relação ao eu da língua materna, rejeitando todo contato direto com a língua estrangeira. Frequentemente apaixonados pela gramática, procuram reduzir a aquisição da língua a procedimentos lógicos e somente podem compreender um enunciado em língua estrangeira se cada termo foi traduzido em língua materna. (Revuz, 1998:225)

Com as palavras de Revuz, encerramos a problemática das interferências e, para formar um quadro mais completo, além das perturbações, desejamos também compreender os possíveis benefícios da utilização da língua materna no processo de aquisição de um segundo idioma.

Como já exposto, muitas das metodologias atuais, pelo menos em médias e grandes escolas de idiomas brasileiras, tem uma posição bastante fechada quando ao uso ou não-uso dessa estratégia. Em seu artigo sobre a língua materna como um recurso mediacional, Terra (2004), citando Lemke (1989), parte do princípio de que a linguagem é uma ferramenta social, servindo para dar direções, negociar, solicitar cooperação, compartilhar informações, elogiar, seduzir, persuadir, etc. Segundo a autora, conversar é uma atividade social e interativa, inclui movimentos corporais e expressões faciais e varia de acordo com o contexto. Afirma, também, que estudos recentes têm se ocupado da necessidade de fazer os alunos assumirem o papel de desencadeadores da interação, algo que costuma ser papel do professor. 
Quanto às similaridades e diferenças entre aquisição de língua materna e língua estrangeira, Terra (2004) lembra não haver consenso entre os especialistas, mas todos concordam que cada aquisição é impulsionada por necessidades diversas: enquanto a primeira língua seria fruto da necessidade de sobrevivência humana, a segunda seria impulsionada por razões de ordem sócio culturais.

Fazendo uma revisão da literatura, Terra (2004) dá indícios de que a língua materna seria relevante como recurso de potencialização do aprendizado de um idioma estrangeiro na medida em que o aluno faria uso de conhecimentos linguísticos previamente adquiridos. Citando Lier (1995), a pesquisadora distingue três aspectos principais referentes à influência da primeira língua na segunda:

1) Cognitivos: Conscientização da linguagem, estratégias de aprendizagem, capacidade de relacionar os novos conhecimentos aos antigos, etc.;

2) Linguísticos: Percepção das similaridades / diferenças entre os idiomas;

3) Interacionais: Abrir oportunidades para conversas significativas, etc.

Em suma, a dosagem do uso da língua materna em situação de aprendizado de novo idioma é a grande questão. Se a usamos em demasia, o aprendiz perde as (raras) oportunidades de contato prático com o novo idioma. Se a excluímos por completo, nós, professores, perdemos a chance de dar uma explicação melhor ou lançar luz sobre um ponto obscuro, de promover mais interação e de estimular a reflexão tanto em termos do respeito às especificidades de cada língua, quanto na busca por traduções mais adequadas.

Sobre as diversas teorias relativas à aprendizagem de línguas estrangeiras, buscamos compor um cenário com as principais perspectivas, para entender de que forma tais correntes se posicionam e, sempre que possível, examinado a origem de algumas das práticas e crenças encontradas em sala de aula.

De acordo com Lovato e Tamanini-Adames (s.d.), em "Teorias, estágios e contextos de aprendizagem de segunda língua", Ellis (1989:248-281) faz uma revisão da literatura sobre o aprendizado de línguas e encontra sete teorias ou modelos de aquisição de L2, refletindo a diversidade de concepções nesses estudos. Vejamos quais são: 
1) Modelo da Aculturação: A aquisição da L2 é apenas um dos aspectos da aculturação. O grau com que o aprendiz acultura- se à nova língua regula o grau de aquisição de L2. Aculturação e aquisição da L2 são, portanto, determinadas pela intensidade da distância (social e psicológica) entre o aprendiz e a cultura da nova língua. A nosso ver, dado que a influência exercida pela cultura, a partir dessa teoria, está intimamente ligada à aquisição, o aprendizado ideal seria aquele por imersão, ou seja, o aprendiz precisaria vivenciar a cultura genuína na qual a língua alvo está inserida. Logo, esse modelo é um dos responsáveis pela crença de que só se aprende uma língua "viajando para fora". Muitos de nossos alunos inclusive relatam isso. De nenhuma maneira pretendemos rejeitar a importância da cultura, ao contrário, mas essa crença leva, em alguns casos, ao descrédito dos cursos de idiomas, que ganham o status de "cursos preparatórios para intercâmbio".

2) Teoria da Acomodação: Enfatiza as relações entre o grupo social do aprendiz (ingroup) e a comunidade falante da língua alvo (outgroup): o que interessa para a aquisição de L2 é o modo como o ingroup se define em relação ao outgroup. Leite (2010) explica que o essencial dessa teoria, como descrita por Giles e Powesland (1975), deriva das pesquisas em similaridade-atração da Psicologia Social e os resultados sugerem que um indivíduo pode levar outro a avaliá-lo mais favoravelmente através da "redução de dissimilaridades entre eles", e que o ato de acomodação pode envolver certos custos para o falante, em termos de mudança de identidade e de esforços empregados. Um possível reflexo dessa teoria, também presente nas falas e crenças de nossos alunos, refere-se ao accent, ao sotaque. E aqui, novamente, é comum o professor se deparar com situações extremas. Enquanto alguns alunos não demonstram qualquer esforço sequer para pronunciar as palavras corretamente e evitar ambiguidades, uma outra parcela preocupa-se mais em soar como um nativo do que com a própria acuidade da pronúncia. Esses querem aprender o ritmo e a entonação dos nativos e parecer-se com eles, talvez para obter, como resultado, a avaliação mais positiva do outro. Na verdade, em termos comunicativos, sabemos que o sotaque - a menos que excessivamente carregado - não influencia na eficácia da comunicação. 
3) Teoria do Discurso: Provém de uma teoria de uso da linguagem na qual a comunicação é o item fundamental do conhecimento linguístico. O desenvolvimento da linguagem deveria ser considerado a partir das descobertas do aprendiz em relação ao significado potencial da linguagem através da participação comunicativa. Relaciona-se aos processos externos, deixando de lado os processos cognitivos que controlam a maneira como o aprendiz e o falante nativo constroem seus discursos, ou como as informações disponíveis pelo discurso são internalizadas. Configura-se como um das bases para as metodologias comunicativas, o caso da escola onde ocorreu a situação de treinamento já descrita e comentada anteriormente. A problemática, para nós, está centrada "nas descobertas do aprendiz". Primeiro, nem tudo é passível de "descoberta", algumas coisas precisam ser explicitadas. Segundo, há um tempo para as descobertas acontecerem. Numa sala de aula, ficaria inviável esperar o tempo de cada um.

4) Modelo da Competência Variável: Distingue o "processo" de uso da linguagem e seu "produto". Assim, a maneira como uma língua é apreendida é um reflexo de como é usada. O produto do uso da linguagem surge de um contínuo de tipos discursivos que vão de um discurso não planejado a um completamente planejado, sendo resultado, então, da competência variável e da aplicação variável de procedimentos para a atualização do conhecimento no discurso. O processo de uso da linguagem é entendido em termos da distinção entre o conhecimento linguístico (competência) e a habilidade de fazer uso desse conhecimento (capacidade). É interessante por se tratar de um modelo que acompanha o processo para entender o produto. Propiciaria talvez maior flexibilidade metodológica, mas exigiria um planejamento bastante elaborado por parte do professor, de acordo com as características de cada turma.

5) Hipótese Universal: Explica a aquisição da L2 por uma faculdade de linguagem "independente", ou seja, o ser humano seria dotado de um conhecimento específico para a língua. Não se baseia em estratégias cognitivas de aprendizagem e, também, opera com o preceito de que o conhecimento linguístico é homogêneo, ignorando a variabilidade. Possivelmente, metodologias baseadas nessa teoria também deixariam o aprendiz por conta de 
suas descobertas.

6) Teoria Neurofuncional: Apoia-se no pressuposto da existência de uma conexão entre a função da linguagem e a anatomia neural. Contribuiu para o entendimento das áreas cerebrais relacionadas ao funcionamento da linguagem. Além disso, destacou aspectos específicos da aquisição da L2, tais como diferenças etárias, fossilização e prática padrão em sala de aula. Aliás, a questão da idade é motivo de muita polêmica e colaborou para a crença de que é difícil aprender uma língua estrangeira depois de adulto. Sobre esse assunto, falaremos mais adiante.

7) Modelo do Monitor de Krashen: Composto por cinco hipóteses centrais. A primeira hipótese diferencia aquisição de aprendizado. Aquisição decorre de um processo subconsciente como resultado da participação natural na comunicação com foco no significado, enquanto o aprendizado é descrito como o processo consciente. A aquisição (para a compreensão e produção de sentenças) e o aprendizado (pelo uso do Monitor) do conhecimento ficariam armazenados em áreas diferentes. A segunda hipótese afirma que as estruturas gramaticais são adquiridas em ordem previsível, que não refletem necessariamente a ordem sequencial escolar. A terceira (hipótese do monitor) supõe o conhecimento aprendido agindo e modificando sentenças geradas pelo conhecimento adquirido, assim, o sistema adquirido (inconscientemente) é responsável pela produção da segunda língua, enquanto o sistema aprendido (conscientemente) responsabiliza-se por monitorar e corrigir tal produção. Na quarta hipótese, a aquisição acontece como resultado do aprendiz ter entendido o input (traduzido por insumo, em português), ou seja, ter entendido tudo aquilo que entra no processo. A quinta hipótese é a do Filtro Afetivo, que se ocupa dos fatores afetivos relacionados à aquisição de L2. Assim, não é suficiente que o aprendiz entenda o input, o sujeito precisa estar "aberto" para recebê-lo. O filtro controla quanto de input vem ao encontro do aprendiz, e quanto dele é convertido em intake, ou aprendizagem. Dessas cinco hipóteses, voltaremos à do Filtro Afetivo mais à frente. 
Em suma, podemos identificar, para quase todas as teorias acima, uma aplicação metodológica desenvolvida a partir desses modelos. Só vemos uma contradição nisso: ao mesmo tempo em que acreditamos na importância de uma linha de trabalho para guiar o professor em suas práticas pedagógicas e unir a escola em torno de um objetivo comum, cada uma dessas teorias e suas consequentes derivações metodológicas privilegiam certos aspectos do processo de ensino-aprendizagem em detrimento de outros. Por isso, pela diversidade humana, cada um de nós está propenso a se identificar mais com um tipo de estratégia de aprendizado. Dito de outra forma, não acreditamos numa metodologia melhor, mas numa mais adequada a cada tipo de aprendiz, sem desconsiderar, claro, o objeto de conhecimento. ${ }^{10}$ O ideal seria que cada aluno, ao procurar um centro de línguas, tivesse a oportunidade de pesquisar sobre a metodologia para descobrir a mais ajustada a seus objetivos e preferências. Como a escolha da escola pelo aluno se dá por diversos motivos (localização, preço, indicação de amigos, tempo de duração), a metodologia nem sempre é a mais apropriada para ele, cabendo ao professor empreender os ajustes. Por isso é vital que as escolas enxerguem o processo de aprendizagem como um todo e não como uma metodologia.

Por fim, Baptista (2000), em "Teorias linguísticas e aquisição e aprendizagem de línguas", também apoiada em Ellis (1985), aponta a existência de três grandes grupos de teorias, nos quais poderíamos "encaixar" a maioria dos modelos acima:

1) Teorias nativistas: A aptidão biológica é o que permite a aprendizagem. Por exemplo, a Teoria da Gramática Universal de Noam Chomsky, defensor de uma faculdade inata para a linguagem, apoiando-se na ideia de que os seres humanos são dotados geneticamente de um conhecimento universal específico para a língua. A Teoria do Monitor de Krashen é também considerada por alguns estudiosos como nativista, pois, ao diferenciar aquisição de aprendizagem, Krashen considera a primeira um conhecimento subconsciente da gramática, portanto, um processo inconsciente, enquanto a aprendizagem resulta do ensino formal, escolar, consciente.

2) Teorias ambientalistas: De bases behavioristas, afirmam a primazia do ambiente sobre os processamentos inatos através da educação e da experiência,

\footnotetext{
${ }^{10}$ Uma língua oriental como chinês, japonês ou coreano exigiria uma metodologia diferente daquela voltada ao ensino do francês ou do italiano, por exemplo.
} 
ou seja, o ambiente social em que se insere o aprendiz é o responsável para o desenvolvimento da língua, e não os processos mentais. Um exemplo seria ao Modelo da Aculturação.

3) Teorias interacionistas: Partem de várias bases teóricas, como da psicolinguística experimental e da psicologia cognitiva, portanto diferem bastante umas das outras. Os modelos interacionistas consideram fatores contextuais (sociais e psicológicos) e processos psicolinguísticos internos do sujeito. Um exemplo seria o Modelo da Competência Variável.

A seguir, discutiremos um pouco a questão afetiva, no que diz respeito a esse estranhamento da outra língua, à dificuldade de aceitação do novo, do outro, do diferente, ou daquilo que "não nos pertence".

\section{A dimensão cultural da língua: a experiência do estranhamento}

Quando se aprende uma língua estrangeira, há muitos elementos envolvidos, além daqueles implicados em qualquer aprendizado, como atenção, memória, disponibilidade para prática e, claro, no caso de uma língua, a fonética e a fonologia. Mas uma das barreiras fundamentais parece ser a questão do "quem sou eu falando essa língua".

Em A língua estrangeira entre o desejo de um outro lugar e o risco do exílio (1998), Christine Revuz escreve: "...aprender uma outra língua é fazer a experiência de seu próprio estranhamento..." (1998:229)

Ou seja, ao falarmos uma língua estrangeira, de certa forma, deslocamos alguma coisa em nossa identidade como pessoa, de como nos reconhecemos, na medida em que precisamos nos adaptar à nova língua. Por exemplo, como já mencionado anteriormente, nosso aparelho fonador deverá ser re-descoberto e re-explorado na tentativa de produção de sons inexistentes em nosso idioma materno.

Esse jogo com os sons nos remete aos primórdios de nossa própria existência e, muitas vezes, tem a capacidade de desestruturar o abrigo seguro que acreditávamos ter construído através da língua-mãe. O próprio som de nossa voz tende a soar de maneira estranha, quase irreconhecível. O resultado disso pode ser uma recusa de libertar-se dos sons da língua nativa. 
A esse respeito, diz Revuz (1998):

Tentar pronunciar o " $\mathrm{r}$ " francês, o "j" espanhol, o som de "th" do inglês, é proporcionar uma liberdade esquecida ao aparelho fonador, explorar movimentos de contração, relaxamento, abertura, fechamento, vibrações que produzem, ao mesmo tempo que os sons, muitas sensações surpreendentes no plano dessa região bucal, tão importante no corpo erógeno. (1998: 221)

De algum modo, portanto, quando se fala uma língua estrangeira, é preciso ser flexível, dar passagem ao "desconhecido" em nós mesmos. Tal fato pode ser tanto aterrorizante quanto fascinante, dependendo da capacidade de cada um tem em permitir-se ser "múltiplo" quando se é "único".

Lembremos do famoso $O$ médico e o monstro, de Robert Louis Stevenson. O ilustre médico, Dr. Henry Jekyll e o assassino Edward Hyde são as duas faces da mesma pessoa. O bem e o mal separados em duas personalidades distintas, fruto de uma desastrosa experiência científica. Dr. Jekyll acreditava que, se pudesse separar suas duas identidades, livrar-se-ia de algo insuportável: "Era uma maldição para a humanidade ter presos um ao outro fardos tão irreconciliáveis, opostos em luta contínua no doloroso limbo da consciência". (1997:80)

A língua estrangeira nos põe, então, em contato com a possibilidade desse outro em nós mesmos. Irreconciliável? Complementar? Não sabemos. Talvez por esta razão, em algum momento, estejamos propensos a entrar em conflito.

Christine Revuz (1998) afirma, ainda: "O que se estilhaça ao contato com a língua estrangeira é a ilusão de que existe um ponto de vista único sobre as coisas, é a ilusão de uma possível tradução termo a termo, de uma adequação palavra à coisa." (1998:223)

A explicação de Revuz (1998) vem ao encontro daquilo que se observa em cursos de idiomas. Alunos com dificuldades frequentemente mostram-se relutantes em entrar em contato e, muitas vezes, aceitar o ponto de vista da língua estrangeira como tal, sem "maternizá-la".

Há o caso de uma aluna que compareceu a uma aula de plantão de dúvidas de uma escola de idiomas com a seguinte pergunta: "Por que give up significava desistir, ao invés de dar acima, como a tradução literal sugere?" Uma vez que a aluna conhecia o significado de give up, deixou-se entrever que o ponto crucial aí não era o significado em si mas o porquê desse significado. Não era, na verdade, uma dúvida. Também não era uma pergunta referente à uma palavra que não se achara no dicionário e cujo significado ficara obscuro. Nem era a pergunta de um pesquisador interessado nas raízes históricas da palavra, procurando uma explicação etimológica para ela. Era, aparentemente, uma pergunta um tanto infantil, sobre o 
porquê as coisas têm esses nomes. Porém, se olharmos essa pergunta menos superficialmente, podemos notar que ela, no fundo, refere-se à aceitação (da aluna) de que aquela palavra pudesse ter um significado diferente do esperado em comparação com a língua materna. Era, talvez, uma espécie de mal-estar, de angústia. Mal-estar que qualquer um que se desloca em direção ao ponto de vista do outro pode sofrer.

No prefácio do livro Walter Benjamin: Tradução e Melancolia, de Susana Kampff Lages (2002), Jeanne Marie Gagnebin inicia uma instigante discussão sobre o mal-estar do tradutor, sempre dividido entre buscar uma linguagem neutra, fiel ao original e incorporar seus elementos linguístico-culturais a esse original.

Dividido entre o desejo de dar vez e voz ao outro, ao autor original, e o esforço próprio necessário à acumulação de múltiplias saberes (linguísticos, históricos, culturais, psicológicos) para cumprir sua tarefa, o tradutor oscila, todo o tempo, entre duas atitudes opostas e complementares: ele é ou um "coitado" ou um "herói" (Paulo Rónai), ele passa de "humilde" à "soberba" (José Paulo Paes) e da depressão à mania como, justamente, um exímio melancólico. Na medida em que ele admira o outro, o original, a autoridade do autor, ele se apaga a si mesmo para melhor deixar brilhá-lo; ele insiste em dizer que não consegue, por princípio e malgrado seus hercúleos esforços, devolver na sua língua a riqueza do texto original; (...) (2002:14-15)

Nesse interessante livro, Lages (2002) percorre a história de melancolia, desde os primórdios da civilização (quando era tida como um "humor", característico especialmente dos sujeitos criativos) até a visão psicanalítica de Freud, no ensaio "Luto e Melancolia", de 1915 (em que Freud atribui ao melancólico um "eu" cindido), aproximando melancolia e atividade de tradução. A tradução tem, para a autora, esse movimento de alternância que Gagnebin explorou em seu prefácio. A tradução nunca parece ser ou (estar) completa. É sempre acompanhada de um sentimento de perda de alguma coisa, já que as diferenças entre as línguas não permitem que elas sejam simplesmente sobrepostas.

Mesmo sem chegar à melancolia, principalmente em seu estado patológico, o sujeito que se propõe a aprender uma língua estrangeira experimenta certa dose de angústia por estar continuamente "cindido" entre o que quer (ou sabe) expressar e as possibilidades que a nova língua lhe apresenta. E pode até parecer que a angústia diminui com o passar do tempo e com a aquisição de vocabulário, de estruturas gramaticais mais complexas, porém essa é uma angústia "primordial", pois nunca será possível, mesmo entre línguas da mesma família, uma concordância linguística ponto-a-ponto.

Por outro lado, se para alguns a língua estrangeira pode ser vivida como uma experiência um tanto desestabilizadora, para outros - talvez para aqueles "que não se 
encontram" em lugar algum, como o foi para o Capitão Nemo de Júlio Verne, ao abandonar a convivência humana na superfície terrestre e exilar-se nas profundezas submarinas, onde, junto a outros poucos homens "sem pátria", inventou sua própria língua - pode ser uma inebriante experiência de liberdade.

Nas palavras de Revuz (1998:224), esse estranhamento no contato com a língua estrangeira pode ser vivido "como uma operação salutar de renovação e de relativização da língua materna, ou ainda como a descoberta embriagadora de um espaço de liberdade."

Daremos prosseguimento ao nosso estudo agora explorando "as pedras no caminho", os obstáculos fundamentais ao aprendizado de línguas por adultos.

\section{Dificuldades de aprendizagem da língua estrangeira por adultos}

Santana (2008), em "A dimensão afetiva no processo de ensino-aprendizagem de línguas estrangeiras", lista e comenta uma série de fatores que podem levar a bloqueios na aprendizagem. Vamos apresentá-los a seguir, sinteticamente.

- Ansiedade: Deve-se ao excesso de expectativa na obtenção de resultados e é, para a grande maioria dos especialistas, o fator que mais causa obstáculos. Costuma ser associada a sentimentos negativos (inquietação, frustração, insegurança, medo, tensão).

- Inibição: Relacionada com o medo de errar; provoca insegurança na hora da produção, principalmente quanto à habilidade oral.

- Extroversão / introversão: A primeira refere-se à necessidade de que outros realcem nosso ego, a auto-estima, a integridade; a segunda, ao grau em que os indivíduos extraem estes sentimentos de si mesmos.

- $\quad$ Auto-estima: Ligada às avaliações que um sujeito faz de si mesmo.

- Motivação - extrínseca ou instrumental: Refere-se à busca de recompensa (estudar uma língua para conseguir uma boa posição no trabalho ou uma boa nota na escola); intrínseca ou resultativa: A própria experiência de aprendizagem é a recompensa (motivação desenvolvida pelo aprendiz como 
resultado de seu êxito durante o processo de aprendizagem); integradora: É própria do sujeito (quer aprender uma língua estrangeira para integrar-se à comunidade de falantes dessa língua, tratando de assimilar uma cultura diferente da sua).

- Estilo de aprendizagem: São as diferentes formas de se aprender alguma coisa, particulares de cada um. Segundo Gardner, há dois tipos gerais de estilo de aprendizagem para línguas - o aprendiz analítico e o aprendiz global. O analítico é aquele que gosta de analisar a estrutura da linguagem, e normalmente só se arrisca a falar quando seguro de que o fará corretamente; o global prefere exporse à língua autêntica, é mais tolerante com as ambiguidades da língua, procura falar ainda que cometa erros e não é muito afeito aos exercícios tradicionais.

- Idade: Está entre as questões mais polêmicas. Alguns especialistas acreditam que quanto mais cedo um indivíduo começar a estudar uma língua estrangeira, maior a chance de êxito. Entretanto, também há estudos que discordam dessa idéia e indicam que no processo de aquisição de um idioma estrangeiro, muitos outros fatores entram em jogo (condições de aprendizagem, fatores ambientais e contextuais, mudanças nos mecanismos mentais, etc). Krashen (1983) e Brown (2001), por exemplo, defendem que a eventual superioridade da criança com relação ao adulto, neste processo, refere-se justamente aos fatores afetivos, isto é, como a criança teria um filtro afetivo baixo, poderia abrir-se ao insumo com mais receptividade e menos questionamentos do que o adulto, o que também é discutível.

- Aptidão para línguas: Alguns especialistas defendem que se trata de uma habilidade natural dos indivíduos. Para Klein (1989) é uma capacidade que supõe condições biológicas favoráveis e conhecimentos linguísticos anteriores disponíveis.

- Perfeccionismo: É a preocupação exagerada a perfeição da forma, com a pronúncia correta, com a estrutura exata, etc. $\mathrm{O}$ aluno prefere não se arriscar a cometer falhas e evita lançar-se no processo de produção, seja oral ou escrito. 
- Carência de autoconfiança: Relaciona-se, normalmente, a transtornos oriundos da educação recebida pelo indivíduo, em casa ou na escola. Pode ser decorrente também do medo de errar, principalmente na produção oral.

- Dependência da eloquência: A habilidade de falar, adquirida ao longo dos anos, em língua materna, representa segurança e poder dos quais é difícil abrir mão. Logo, a experiência de começar tudo de novo, na língua estrangeira, pode gerar insegurança e ser traumatizante.

- Autoconsciência: Refere-se à consciência da própria imagem e a capacidade de imaginar o que os outros pensam de nós. É ruim quando há preocupação excessiva.

- Provincianismo: Representa uma forma extrema de monocultura, em que o sujeito fecha-se naquilo com que se identifica e sente-se inseguro fora deles. Também pode caracterizar-se pela auto-suficiência de uma determinada língua estrangeira em detrimento das demais.

Dos fatores apresentados por Santana (2008), gostaríamos de destacar dois - idade e ansiedade - à luz da teoria piagetiana, de modo que esta seção possa dialogar com as próximas, as quais tratam da teoria de Piaget, propriamente dita.

a) Idade: Assunto bastante polêmico, cujas pesquisas chegam a diferentes conclusões. Tentaremos destacar alguns pontos e fazer algumas relações.

Como já visto anteriormente, para Krashen há uma vantagem da criança em relação ao adulto em dois fatores: primeiro quanto ao Filtro Afetivo, que está baixo nas crianças e, consequentemente, deixa o aprendiz aberto aos insumos. Segundo, "quanto mais jovem, melhor" porque, na tenra idade, a língua seria adquirida, isto é, assimilada por mecanismos subconscientes. Quanto mais velho, menores as chances disso acontecer. Para o adulto, restaria aprender a língua, através da instrução formal e de processos conscientes.

No artigo intitulado "Estratégias de preservação cognitiva em indivíduos idosos: o papel da aprendizagem de uma língua estrangeira", Marzari, G.Q., Santos, C.G. \& Zimmer, M.C. (2012) começam discutindo a questão da plasticidade cerebral. As autoras afirmam que, até o século passado, acreditava-se que o cérebro não tinha condições de regeneração 
espontânea após uma lesão. Estudos atuais, porém, demonstram que há certa capacidade de adaptação e reorganização do SNC, devido à plasticidade cerebral. Na verdade, alterações no cérebro ocorrem ao longo da vida e, nesse sentido, a plasticidade cerebral está ligada à memória, à aprendizagem e à aquisição de experiências. Logo, quanto mais exposição a estímulos ambientais, maior a plasticidade. Com o avanço da idade, o cérebro também envelhece, há morte de neurônios e queda no número de sinapses, que configura a perda cognitiva, mas, em qualquer idade é possível aprender algo novo (como uma língua) e contribuir com o desenvolvimento da plasticidade cerebral.

Quanto à idade ideal para se aprender uma língua, a crença dominante é a de que quanto mais jovem melhor. Segundo Marzari, G.Q., Santos, C.G. \& Zimmer, M.C. (2012), essa concepção teve origem na Hipótese do Período Crítico, proposta pelos neurocirugiões Penfield e Roberts (1959), e depois retomada pelo psicolinguista Lenneberg (1967). Para esses pesquisadores, na puberdade a plasticidade cerebral atinge seu ápice e nesse período ocorrem mudanças relevantes no cérebro humano. Para Lenneberg (1967), até três anos de idade, o aparecimento da linguagem se daria por interação entre a maturação e o aprendizado. De três anos até a adolescência, a aquisição permaneceria favorecida, pois o sujeito ainda estaria sensível a diversos estímulos e flexível quanto à organização cerebral. Após a puberdade essa sensibilidade e flexibilidade declinariam rapidamente. A idade, por esse prisma, é um fator determinante no aprendizado ou fracasso. Há ainda, uma versão mais moderada, proposta por outro grupo de estudiosos, para quem a idade não seria determinante, mas significativa.

Nejadansari e Nasrollahzadeh (2011) examinaram alguns efeitos da idade na aquisição de uma segunda língua, de acordo com quatro critérios: os efeitos da idade no processo de aquisição, na taxa de aquisição, no sucesso em relação à língua e na aquisição de uma proficiência oral (próxima à) nativa. Após discutirem vários estudos e apresentarem inúmeras pesquisas, admitem que tais trabalhos chegaram a diferentes conclusões. $\mathrm{Na}$ tentativa de entrar num consenso, os autores indicam alguns resultados comuns a várias pesquisas:

- Adultos parecem ter uma vantagem inicial na taxa de gramática adquirida, porém são ultrapassados pelas crianças que recebem exposição massiva à língua estrangeira.

- Apenas crianças seriam capazes de adquirir sotaque nativo em contextos 
informais, porém há divergências em relação à idade crítica (até 6 anos para alguns, até o início da puberdade para outros). Adultos precisariam de treinamento formal para atingir o sotaque nativo.

- Crianças estão mais propensas a adquirir competência gramatical nativa. O período crítico fica por volta dos 15 anos. Porém alguns adultos podem ser bem sucedidos e alcançar competência linguística completa.

- A despeito de alcançar ou não proficiência nativa, crianças estão mais propensas a atingir níveis mais altos de resultados.

- O processo de aquisição da gramática não é afetado substancialmente pela idade, mas a pronúncia tende a ser.

Em suma, em todos os casos, a problemática da idade parece exercer maior influência na condição de se atingir uma proficiência nativa. Por questões de plasticidade, sensibilidade, filtro afetivo, etc., a criança estaria mais predisposta que o adulto. Dito de outra forma, por questões muito mais maturacionais. Para o adulto, seria possível - eventualmente uma aproximação da proficiência (gramatical ou fonética) nativa através de muito treino formal, por exemplo, por imitação dos sons nativos, como mostra uma das pesquisas citadas por Nejadansari e Nasrollahzadeh (2011).

No entanto, em toda essa discussão, em nenhum momento alguém se perguntou: Qual, afinal de contas, é o objetivo da aquisição de uma proficiência nativa? Será que os adultos participantes das pesquisas tinham essa meta?

Não vamos negar a importância social de se comunicar bem em uma língua, inclusive na nativa. Mas o quanto seria um problema não atingir uma proficiência nativa, porém comunicar-se eficientemente? E o que é a proficiência nativa? Quem são os sujeitos modelos?

Se pensarmos em termos de teoria piagetiana (que será melhor desenvolvida na próxima seção), podemos seguir o seguinte raciocínio:

Já tendo atingido o estágio formal, caracterizado pela abstração total do pensamento, os adultos têm a capacidade (e, nesse caso, a vantagem) de fazer planos e projeções futuras e estabelecer metas. 
As metas nascem de uma necessidade que desestabiliza (desequilibra, em termos piagetianos) o sujeito e o faz procurar uma solução. Face ao desequilíbrio, o sujeito procura se reequilibrar, readaptar-se.

A busca por readaptação, envolve, por sua vez, fatores afetivos e cognitivos, isto é, ele precisa pensar COMO fazer (essencialmente cognição) e O QUÊ fazer (essencialmente afetividade).

Em termos práticos, se ele precisa aprender uma língua para o trabalho, vai escolher um curso que preencha suas expectativas (Para Piaget, a afetividade envolve escolhas, portanto a escolha seria O QUÊ, enquanto estudar a língua nesse curso seria COMO).

Ocorre que o sujeito tem interesses em sua vida, e estes são organizados num sistema de valores, orientados do centro (os valores mais fortes) para a periferia (os mais fracos). Cada novo interesse assume uma posição (não necessariamente para sempre) nessa hierarquia.

Posicionam-se assim porque o valor é a energética depositada pelo sujeito naquele interesse. Então se a língua estiver posicionada mais na periferia, significa que lhe sobra menos energética. E esse é o ponto onde queremos chegar. O quanto de energética o adulto depositará em seu estudo vai depender de quais são seus verdadeiros interesses. Para nós, portanto, a afetividade é uma questão de valor, não de filtro.

Concluindo:

1) A meta a ser alcançada, estabelecida pelo adulto, vai depender de sua necessidade de adaptação. Se ele não precisar de uma proficiência nativa, talvez não se mova nessa direção. O que os estudos não mostram é justamente isso, será que o adulto da pesquisa tem como meta ser tão proficiente como um nativo?

2) Os valores mais centrais do adulto são aqueles mais propensos a produzir sucesso, devido à qualidade de sua energética. Atribuindo pouca valorização à língua, não resultaria em um desejo de aperfeiçoamento que o aproximasse da proficiência nativa.

b) Ansiedade: Parece-nos, de longe, o mais complexo de todos os fatores citados, a começar pela definição de seu conceito que, para alguns especialistas, pode ter feito diferença inclusive no resultado de algumas pesquisas. Além disso, em nossa própria investigação sobre 
o assunto, encontramos um grande número de variáveis a serem consideradas, ou seja, além de possuir uma característica multifacetada, pode ter várias origens: tendências pessoais psicológicas, condições fisiológicas, aspectos relacionados ao ambiente, etc.

Para Krashen (1985), quem já mencionamos anteriormente, os fatores afetivos têm uma grande relevância no processo de aquisição/aprendizado linguístico, portanto o Filtro Afetivo desempenha um papel determinante nesse processo pois, estando "alto", não permite a passagem do input, ainda que o sujeito o tenha compreendido adequadamente. Segundo o linguista, o Filtro Afetivo trata-se, na verdade, de um "bloqueio mental" e pode ter várias origens (ansiedade, desmotivação e baixa autoconfiança). Logo, para os alunos dotados de um Filtro Afetivo "baixo", a língua seria aprendida/adquirida com mais eficácia. Seria o caso das crianças, pois, apesar de poder existir um Filtro Afetivo nelas também, ele ganha força a partir da puberdade e nunca mais atingirá um nível muito baixo novamente. Apesar da ênfase na importância do componente afetivo, o autor não desdobrou muito essa parte de sua teoria, deixando aí algumas lacunas. A imprecisão na origem e na formação do filtro e a falta de explicação sobre seu funcionamento renderam a Krashen algumas críticas.

Em “A ansiedade e o aprendizado de língua estrangeira”, Welp (2009) cita Schumann (1997), que fala da "memória emocional de experiências passadas", ou seja, através de um sistema envolvendo a amígdala, o córtex orbitofrontal e o próprio corpo haveria a formação de um filtro através do qual se poderia determinar a relevância da experiência pessoal subsequente. Seguindo por esse raciocínio, Schumann complementa a teoria de Krashen, afirmando que o Filtro Afetivo não opera apenas através dos três fatores mencionados por Krashen (ansiedade, desmotivação e baixa autoconfiança), mas ainda por uma combinação do histórico de preferências e antipatias que julga a língua estrangeira e a cultura na qual se insere, da mesma forma que avalia o material usado em sala de aula, as atividades, o professor, etc.

Citando MacIntyre e Gardner (1991), Welp (2009) nos explica que a psicologia distingue diversas categorias de ansiedade, como a "ansiedade de situação específica", caracterizando a natureza persistente e mutltifacetada de algumas ansiedades. Para esses autores, a ansiedade é a interação da pessoa na situação que a provoca - pois algumas situações provocam ansiedade; outras, não. Seria necessário considerar tanto a individualidade quando o contexto. Além disso, os autores sugerem que, no caso das línguas, são as experiências negativas persistentes que geram ansiedade, dito de outra forma, a ansiedade de língua estrangeira baseia-se em expectativas negativas que produzem 
preocupação e emotividade, interferindo na cognição e podendo resutar em déficits de desempenho.

Segundo Welp (2009), Horwitz, Horwitz e Cope (1986) defendem um tipo de ansiedade específica do aprendizado de línguas estrangeiras, responsável pelas sensações de desconforto em sala de aula e proveniente de vários fatores, inclusive da falta de habilidade comunicativa. Acreditam, contudo, que as maiores fontes de ansiedade são a fala - "a conversação livre e despreparada é desconcertante" - e a compreensão oral, pela dificuldade de discriminação dos sons e estruturas. Horwitz et al. (1986) descrevem três componentes da ansiedade da língua: apreensão comunicativa (o aprendiz tem pouco vocabulário para expressão de suas ideias), medo da avaliação social e ansiedade de teste. Horwitz (1986) desenvolveu, ainda, uma "Escala de Ansiedade de Aula de Língua Estrangeira", com o propósito de fornecer um instrumento padrão para mensurar a ansiedade do contexto escolar.

Do exposto, nota-se, que a maioria dos pesquisadores tende a considerar a ansiedade como negativa, tanto no território de ensino-aprendizagem, quanto em outros domínios. Negativa principalmente porque, na visão desses pesquisadores, interfere nos processos cognitivos causando déficit.

Para Piaget (1954), toda conduta é, ao mesmo tempo, afetiva e cognitiva. Não faz uma distinção dicotômica entre uma coisa e outra pois, para ele são indissociáveis. Mas, logo no início de seu texto "As relações entre inteligência e afetividade no desenvolvimento da criança”, admite que tal afirmação - afetividade e inteligência são indissociáveis - pode gerar mal-entendidos, e apressa-se em explicar seu ponto de vista.

A afirmação "afetividade e inteligência são indissociáveis" pode significar, primeiro, que a afetividade intervém nas operações da inteligência, causando "perturbações" tanto da ordem dos atrasos (assumindo então carga negativa) quanto da ordem das acelerações (carga positiva).

Num segundo sentido seria possível imaginar que a afetividade interfere nas estruturas cognitivas, da inteligência, ou seja, que a afetividade é fonte de estruturas cognitivas originais.

Para Piaget, apenas o primeiro sentido é válido. Ainda que a funções cognoscitivas e as funções afetivas sejam indissociáveis, uma coisa não pode ser ponto de gênese para outra.

Explicando melhor: mesmo nas formas mais abstratas de inteligência, por exemplo, na resolução de um problema de álgebra, a princípio há uma necessidade de solução que desequilibra o sujeito, fazendo com que ele busque se reequilibrar (ou adaptar-se). Durante todo o trabalho, os sentimentos de êxito ou fracasso, de agrado ou desagrado vão constituir a 
energética para a realização da ação, independentemente de serem sentimentos considerados negativos ou positivos.

Por exemplo, imaginemos que um sujeito tenha um sentimento de desagrado ao fazer uma tarefa. Podemos pensar que ele vai se esforçar para completar e tarefa e, assim, minimizar esse sentimento, ao invés de pensarmos que o desagrado vai atrapalhar a realização dessa tarefa apenas porque se trata de um sentimento negativo.

Porém a afetividade não criará novas estruturas no plano intelectual, nem a inteligência criará novas funções afetivas. A afetividade é a fonte energética da qual depende o funcionamento da inteligência, não sua estrutura. E apesar de seu papel "perturbador" incontestável, Piaget não a concebe como desorganizadora da capacidade intelectual, mas como reguladora.

Portanto, sobre a ansiedade e o ensino de línguas, na ótica piagetiana, podemos extrair duas reflexões:

1) Por mais negativa que a ansiedade seja para a maioria dos especialistas, na visão piagetiana ela não poderia produzir déficits cognitivos, pois, dessa forma, estaria interferindo na própria estrutura da inteligência;

2) A ansiedade é reguladora da inteligência, o que não significa necessariamente desorganizá-la. Vai depender da interação entre a qualidade da regulação (por exemplo, do tipo de ansiedade), e também da necessidade que gerou o desequilíbrio (ou seja, da necessidade que levou o aluno a estudar a língua estrangeira).

Por tudo isso, defendemos o trabalho com as necessidades específicas do aluno ou do grupo, o trabalho de conscientização de cada um deles em relação às suas metas, e a orientação quanto a estratégias de aprendizagem mais reflexivas e eficazes. Se Piaget tinha razão (e acreditamos que sim), os aspectos afetivos, incluindo a ansiedade não são sempre os grandes “vilões". É preciso, antes de tudo que haja um desequilíbrio (uma pergunta, uma demanda) para que o sujeito busque seu reequilíbrio, colocando em funcionamento tanto seus recursos cognitivos disponíveis quanto a energética (a afetividade) para sua ação.

De agora em diante, trataremos da teoria piagetiana propriamente dita, relacionandoa aos objetivos de nossa pesquisa. 


\section{Língua estrangeira como objeto de conhecimento: uma visão piagetiana}

O que move o sujeito a aprender? E como ele produz conhecimento? Em sua teoria, Piaget procurou responder a essas e outras perguntas. Agora, à luz de suas ideias, tentaremos responder às nossas próprias perguntas. A primeira delas é "o que move o sujeito a aprender uma língua estrangeira?"

Em primeiro lugar, a teoria piagetiana, conhecida como Epistemologia Genética, buscava a "gênese do conhecimento". Durante toda sua vida, Jean Piaget dedicou-se a examinar essa questão sob diversos prismas. A Teoria da Equilibração das Estruturas Cognitivas, desenvolvida já nos últimos anos de sua vida, procura desvendar o processo de aquisição de novos conhecimentos e, de certa forma, responde à primeira questão.

O processo de aquisição do conhecimento - ou aprendizagem - é um processo de equilibração cognitiva, ligado diretamente ao desenvolvimento, em que o sujeito recebe (assimila) as informações do ambiente e as modifica (acomoda), modificando suas estruturas mentais de modo a estar sempre atualizado no mundo (adaptado a ele).

$\mathrm{Na}$ verdade, o que move o sujeito a aprender qualquer coisa provém de uma necessidade de adaptação ao mundo, ao ambiente no qual vive. Na visão piagetiana, inteligência é, portanto, adaptação.

Logo, o movimento em direção ao aprendizado uma língua estrangeira vem da necessidade de adaptar-se a uma situação nova, por exigências sociais, profissionais ou pessoais. Aqui, independentemente da crença na obrigatoriedade de dominar uma língua, trata-se de uma situação em que o sujeito está desequilibrado e precisa se reequilibrar para se adaptar.

Pensemos em dois sujeitos, funcionários de empresas de grande porte, que participam de um treinamento em inglês. Para um deles, a falta de conhecimento do idioma inglês impede que ele aproveite o treinamento. O outro, apesar da falta de conhecimento linguístico, faz um esforço para resolver o problema, adaptar-se de outra forma, utilizando outros tipos de conhecimento que lhe permitam desvendar o que está sendo dito, como por exemplo, analisar os gestos corporais dos falantes, volta sua atenção às imagens, procura uma conexão entre o treinamento e sua prática profissional, enfim, descobre outros índices que o ajudem na tarefa. No primeiro caso, a necessidade do conhecimento linguístico é urgente, pois o sujeito precisa encontrar meios de restabelecer seu equilíbrio. No segundo caso, o sujeito resolveu o problema do desequilíbrio, mesmo não tendo sido a partir de um conhecimento específico, o conhecimento do idioma. Nesse caso, a falta do conhecimento linguístico pode 
não ser o mais relevante, não chegando a instaurar, no sujeito, uma necessidade. Imaginemos, agora, que ambos resolvam procurar um curso de idiomas. As motivações de cada um - que envolvem os interesses, ou seja, a energética da ação - são claramente diferentes, porque as necessidades de cada um não provêm do mesmo tipo de desequilíbrio.

O interesse pelas línguas representa, então, a energia que o sujeito tenciona dispender para realizar a ação. Acreditamos que, quanto mais qualitativo for esse interesse, mais privilegiado - mais centralizado - estará o valor (relativo a esse interesse) em sua escala pessoal. Dessa forma, um sujeito aguentaria melhor as dificuldades ou desconfortos que podem surgir no contato com o novo idioma quando o valor atribuído ao conhecimento da língua está mais centralmente localizado. Dito de outra forma, quando confere um valor central à sua possibilidade de interação com o mundo, nesse caso em forma de comunicação especialmente oral.

Em seguida, a resposta de Piaget à pergunta "como se constrói conhecimento?" Sistematizaremos os conceitos de equilibração, acomodação e assimilação, e veremos como foram descritos os quatro patamares de equilibração. 


\section{Introdução à teoria de Jean Piaget: construção da inteligência e da afetividade}

Jean Piaget nasceu em Neuchâtel, na Suiça francesa, em 1896. Licenciou-se em Ciências Naturais aos 21 anos e, no ano seguinte, obteve o título de doutor em Ciências, com uma tese sobre moluscos. Lecionou nas Universidades de Genebra, Neuchâtel e Lausanne, na Suiça, e em Sorbonne, na França. Interessou-se por filosofia, tendo contato com as obras de Kant, Bergson e Husserl. Interessou-se também por psicanálise, tendo contato com as obras de Freud.

Essa abrangente formação permitiu a Piaget posicionar-se de maneira privilegiada quanto ao tema do desenvolvimento humano, seu principal objeto de estudos. Mais precisamente, a pergunta que guiou suas investigações foi de caráter epistemológico: "como se constrói conhecimento?" Daí ser o fundador da Epistemologia Genética, ou gênese do conhecimento.

\subsection{Construção da inteligência}

A novidade da teoria piagetiana é assumir uma visão interacionista, partindo do pressuposto de que há uma relação de interdependência entre sujeito e objeto do conhecimento, pois considerava insuficiente explicar o desenvolvimento humano a partir somente de programações inatas ou somente de experiências com os objetos, o que constituía as duas grandes correntes dicotômicas da época. Ou seja, partindo dessa visão, o desenvolvimento humano se dá através de um mecanismo de auto-regulação, que tem uma base inata, mas é construído na e pela interação do sujeito (e seu organismo físico) com o ambiente físico e social. Dessa forma, os fatores envolvidos no desenvolvimento mental compreendem maturação orgânica, experiência (tanto física quanto lógico-matemática), interação social e equilibração.

Equilibração é um conceito fundamental para entender a teoria piagetiana: "O desenvolvimento, portanto, é uma equilibração progressiva, uma passagem contínua de um estado de menor equilíbrio para um estado de equilíbrio superior" (Piaget, 1964/2007:13). Ou seja, para Piaget o organismo busca continuamente um estado de equilíbrio com o meio, mas podem acontecer perturbações nesse equilíbrio que forçam uma tentativa de readaptação do sujeito ao meio. Em outras palavras: a necessidade de adaptação gera um desequilíbrio, que por sua vez gera uma demanda de reequilíbrio. Assim, podemos dizer que inteligência é 
adaptação ao mundo. Equilibração tem um caráter universal, no sentido de que ocorre em todos os sujeitos, porém, como depende também da interação sujeito-ambiente, pode sofrer variações, por exemplo, devido ao conteúdo das experiências de cada um desses sujeitos.

A busca por adaptação envolve dois processos distintos e, ao mesmo tempo, simultâneos: assimilação e acomodação. Na assimilação, o sujeito, em contato com o objeto de conhecimento, incorpora elementos novos às suas estruturas mentais e, na acomodação, ajusta as estruturas para que elas incorporem os novos objetos.

Segundo Piaget (1964/2007), há quatro grandes patamares gerais de equilíbrio, chamados estágios, que são alcançados através do mecanismo de equilibração acima descrito. A novidade de cada estágio é o aparecimento de uma estrutura global nova, que incorpora a anterior. São eles: sensório-motor, pré-operatório, operatório concreto e operatório formal. A seguir, de forma sucinta, veremos as principais características de cada estágio e nos deteremos mais no período operatório formal no qual, teoricamente, estariam classificados os adultos.

Sensório-motor (entre 0 e 2 anos, em média): A partir de reflexos neurológicos básicos, o bebê passa a construir esquemas de ação para assimilar mentalmente seu meio. Trata-se de um tipo de inteligência prática, cuja lógica é a das ações. Nesse período, acontece a passagem "do caos ao cosmos", nas palavras de Piaget, ou seja, de uma realidade desorganizada a uma realidade cada vez mais organizada, através da construção do real, cujas categorias - objeto, espaço, tempo, causalidade - foram inspiradas pela filosofia de Kant. Essas noções começam a ser construídas pela ação. O contato do bebê com o meio é direto, pois ainda não há representação.

Pré-operatório (entre 2 e 6 anos, em média): Nesse período, a criança não está mais limitada a seu meio sensorial direto, pois há, aqui, o início da socialização da ação. Graças à linguagem verbal, ocorre a interiorização e a socialização do pensamento. Esse período propicia o aparecimento da função semiótica, ou seja, da capacidade de diferenciar objetos de seus representantes, o que pode ser observado através de algumas condutas: imitação, imagem mental, jogo simbólico, representação gráfica (desenho) e linguagem verbal. Dessa forma, a criança já é capaz de representar - surge, então a inteligência representacional. Porém, apesar de serem capazes de imaginar e de pensar de modo intuitivo, esse pensamento ainda é irreversível e impermeável à argumentação do outro. Há um egocentrismo intelectual, na medida em que o pensamento da criança está centrado em si mesmo. 
Operatório concreto (entre 7 e 12 anos, em média): É o período que marca o início do pensamento lógico, um pensamento em sistema, mais permeável e que busca explicação para além dos fatos. Consequentemente, a criança consegue relacionar diferentes aspectos e abstrair dados da realidade, além de não se limitar a uma representação imediata. Desenvolve, também, a reversibilidade, isto é, a capacidade de representar uma ação em sentido inverso. Por isso esse período é chamado "operatório", pois "operação" significa "qualquer ação que só pode ser entendida num sistema de ações coordenadas e reversíveis". Porém, a criança é ainda muito dependente do mundo concreto para fazer tais abstrações. Nesse tipo de pensamento, o possível é igual ao real.

Operatório formal (a partir de 12 anos, em média): É o período em que o pensamento eleva-se à segunda potência, ou seja, a criança é capaz de pensar sobre seu pensamento. Como a representação agora permite abstração total, ela se desprende da realidade concreta, sendo capaz de tecer hipóteses e fazer deduções. É capaz de pensar criticamente sobre os sistemas sociais, sobre os códigos e condutas sociais, discutir e construir seus próprios valores morais e criar teorias. Consequentemente, é o período no qual se começa a construir programas de vida e fazer projeções no futuro. Para esse pensamento, o possível é maior que o real. Foi o último patamar descrito por Piaget, não porque achasse que o desenvolvimento termina aí, mas porque entendeu ser esse é o tipo de inteligência mais potente no desenvolvimento.

Esta será a forma predominante de raciocínio usada pelo adulto ${ }^{11}$, mas os conhecimentos continuarão a ser ampliados e aprofundados, já que o adulto continuará sofrendo desequilíbrios vida afora. Para se reequilibrar, precisará lançar mão de suas estruturas cognitivas (e afetivas) e, mesmo que não haja uma forma de inteligência mais potente descrita por Piaget, o adulto, na busca por soluções, tem à sua disposição a sofisticação do pensamento abstrato, que lhe permite construir hipóteses, "testá-las" mentalmente e projetá-las no futuro.

Nossos alunos estariam nesse período, em que o possível está além de suas vidas imediatas. Dessa maneira, eles criam hipóteses e fazem projeções para o conhecimento que estão se propondo a adquirir. E esse é um dos aspectos mais relevantes a ser considerado no

\footnotetext{
${ }^{11}$ Lembramos que nem sempre o adulto atinge o período operatório-formal.
} 
processo de ensino-aprendizagem.

Os estágios apresentados por Piaget seguem, assim, uma ordem sequencial, pois uma estrutura nova incorpora uma anterior, variando quanto às idades médias de surgimento, conforme as experiências individuais.

A ordem de sucessão é constante, embora as idades médias que os caracterizam possam variar de um indivíduo para outro, conforme o grau de inteligência, ou de um meio social a outro. O desenrolar dos estádios é, portanto, capaz de motivar acelerações ou atrasos, mas a ordem de sucessão permanece constante nos domínios (operações, etc.) em que se pode falar desses estádios. (Piaget e Inhelder, 1966:135)

Interessante notar que, quando Piaget afirma que há uma ordem sequencial não é simplesmente como crescer e amadurecer - senão em nada seria diferente do inatismo - mas as estruturas mentais são pontos de gênese para a construção de novas estruturas.

Cada estágio é caracterizado pela aparição de estruturas originais, cuja construção o distingue dos estágios anteriores. O essencial dessas construções sucessivas permanece no decorrer dos estágios ulteriores, como subestruturas, sobre as quais se edificam as novas características. (Piaget, 1964/2007:15)

Semelhante à construção de um edifício, são construções progressivas, em que não se pode pôr o telhado se não houver pilares e paredes; não se pode levantar as paredes sem a fundação. É nesse sentido que são sequenciais. Mas não podemos nos esquecer de que a inteligência está voltada para a adaptação ao mundo e isso ocorre através de momentos de desequilíbrio, geradores de uma demanda. Ou seja, deixemos claro que precisa haver uma demanda, senão o sujeito não vai se esforçar para resolver um problema. Por outro lado, não é qualquer experiência que gera uma demanda, mas uma experiência significativa, uma que deixe o sujeito tão perplexo a ponto de querer recuperar seu equilíbrio: "A criança, como o adulto, só executa alguma ação exterior ou mesmo inteiramente interior quando impulsionada por um motivo e este se traduz sempre sob a forma de uma necessidade (uma necessidade elementar ou um interesse, uma pergunta, etc.)" (Piaget, 1964:16)

Logo, a base da experiência está nas ações do sujeito sobre o mundo e os objetos. A ação faz com que o sujeito conheça o mundo, portanto, é a mediação privilegiada para Piaget. Importante ressaltar, também, que pode ser tanto física quanto mental: "A ação humana consiste neste movimento contínuo e perpétuo de reajustamento ou de equilibração". (Piaget, 1964/2007:16)

Piaget afirma, também, que : "Afetividade e inteligência são, assim, indissociáveis e 
constituem os dois aspectos complementares de toda conduta humana" (Piaget, 1964/2007:22). E continua:

Como já entrevimos, desde o período pré-verbal, existe um estreito paralelismo entre o desenvolvimento da afetividade e o das funções intelectuais, já que estes são dois aspectos indissociáveis de cada ação. Em toda conduta, as motivações e o dinamismo energético provêm da afetividade, enquanto que as técnicas e o ajustamento dos meios empregados constituem o aspecto cognitivo (senso-motor ou racional). Nunca há ação puramente intelectual (sentimentos múltiplos intervêm, por exemplo: na solução de um problema matemático, interesses, valores, impressões de harmonia, etc.), assim como também não há atos que sejam puramente afetivos (o amor supõe compreensão). (Piaget, 1964/2007:36).

Sobre a afetividade, do ponto de vista piagetiano, vamos tratar a seguir, procurando uma relação entre construção de valores e aprendizado de línguas estrangeiras.

\subsection{Relações entre afetividade e inteligência}

Em primeiro lugar, o termo "afetividade" compreende, para Piaget (1954), os sentimentos propriamente ditos, bem como as tendências, em particular a "força de vontade". Mesmo a indiferença é considerada por Piaget uma tonalidade afetiva.

Piaget (1954) distingue "funções cognitivas" (que compreendem desde percepção e funções sensório-motoras até operações formais) e "funções afetivas" quanto à natureza de cada uma, mas afirma que, na conduta de um sujeito, essas funções aparecem concomitantemente e são indissociáveis. Em relação à inteligência abstrata, por exemplo, quando um aluno procura uma solução para um problema, o interesse está diretamente envolvido nesse processo, porque a necessidade de resposta gerada pelo problema move o sujeito a procurar resolvê-lo, sendo o interesse a parte afetiva desse processo. Além disso, os sentimentos de êxito e fracasso permeiam todo esse trabalho de procura por soluções.

Quanto à percepção, os sentimentos de agrado e desagrado perpassam toda a seleção perceptiva. Ao observar uma figura complexa, sujeitos diferentes perceberão elementos diferentes, e estas seleções perceptivas são inspiradas afetivamente pelos diversos interesses de cada um desses sujeitos.

Afetividade, portanto, é a fonte energética da qual depende o funcionamento da inteligência, porém sem modificar suas estruturas. E se é fonte de energia e permeia a inteligência, pode, portanto, influenciar no desenvolvimento, provocando atrasos ou 
acelerações no desenvolvimento intelectual.

\subsection{Afetividade e construção de valores}

Levando em conta o já dito anteriormente, vale lembrar que qualquer aprendizado, na visão piagetiana, é fruto de um desequilíbrio provocado por uma necessidade, uma demanda por adaptação. Importante retomar esse aspecto, na medida em que tratamos de aprendizagem de línguas estrangeiras. A primeira coisa a se investigar é, portanto, qual é a origem da necessidade de quem se propõe a aprender uma nova língua. Já discutimos que as demandas têm, cada vez mais, partido da sociedade. Ou seja, são mais "extrínsecas".

Ryan and Deci (2000) estudaram as teorias relativas a motivações e chegaram às concepções de motivação "intrínseca" e motivação "extrínseca". Para os pesquisadores, motivação intrínseca reflete a propensão natural do ser humano em aprender, em outras palavras, aprende-se por interesse e prazer. Já a motivação extrínseca varia consideravelmente quanto à sua própria autonomia e pode tanto refletir uma real auto-regulação quanto pressões externas.

Para Piaget (1954), interesse é a energética que regula a interação com o objeto de conhecimento e a qualidade desses interesses forma um sistema pessoal de valores, organizados hierarquicamente. Tomando as concepções de Ryan e Deci, adotamos os termos "extrínseco" e "intrínseco" nessa pesquisa. O extrínseco está então relacionado ao valor mais periférico hierarquicamente - pois a motivação extrínseca apresenta-se menos estável - e o intrínseco relaciona-se ao valor numa posição hierarquicamente mais central, na medida em que a motivação intrínseca representa a propensão natural à aprendizagem, sendo mais estável. Assim, uma meta colocada pelo outro estaria hierarquicamente mais periférica em relação às metas colocadas pelo próprio sujeito.

Em 1953-1954, na Sorbonne, Piaget apresentou suas formulações sobre afetividade.

Diz Souza (2001):

Nesta ocasião, Piaget pretendeu retomar algumas proposições sobre os aspectos psicológicos das condutas apresentando sua formulação de correspondência e finalizando com sua proposição de compreensão da moralidade na criança, ou seja, como uma intersecção entre elementos intelectuais, afetivos e sociais. (Souza, 2001:252) 
Segundo Souza (2001), apoiado nas ideias de Claparède e Janet, Piaget chega a algumas definições de valor:

1) valor é a expansão da atividade do eu na conquista do universo;

2) valor é intercâmbio afetivo com o exterior (objeto ou pessoa);

3) valor é o aspecto qualitativo do interesse.

Essa terceira definição é exatamente o ponto de partida de nossa pesquisa. Pensamos que o interesse em aprender inglês, ligado às motivações e demandas sociais, dá suporte a um aprendizado efetivo quando se torna um valor, ou seja, na medida em que há qualidade na relação aluno-idioma. Se pensarmos nas estruturas cognitivas, quando há um desequilíbrio adaptativo, ou seja, quando as estruturas cognitivas que o sujeito possui já não dão conta de resolver seus problemas.

Ainda, em Inconsciente afectivo e inconsciente cognoscitivo (1975), Piaget diz que a afetividade e suas privações podem, certamente, acelerar ou atrasar o desenvolvimento cognitivo, mesmo sem modificar as estruturas cognitivas. Os mecanismos afetivos e cognitivos são sempre indissociáveis, porém distintos: a afetividade disponibiliza a energética enquanto a cognição fornece as estruturas. Em resumo, o papel da inteligência é organizar os meios para atingir a meta. Já a afetividade fornece o "combustível", a energética das condutas. Logo, "como fazer" é essencialmente inteligência e "o que fazer" é em essência, afetividade.

Por fim, o "como fazer" nos remete às escolhas feitas por cada um de acordo com suas demandas, o que nos leva a perguntar: "Em que medida os adultos, pressionados por demandas sociais, estão escolhendo estudar idiomas?" Visto que uma língua não é apenas uma lista de palavras num dicionário, mas carrega toda uma cultura, como esses adultos, impelidos a estudar um novo idioma, e a partir desse interesse - que é mais social que pessoal, mais extrínseco que intrínseco - construirão valores fortes o suficiente para suportarem dificuldades e desconfortos?

Para tentar responder a essas questões, conduzimos uma pesquisa com adultos, estudantes de um curso de idiomas de médio porte na cidade de São Paulo, a qual apresentaremos na Segunda Parte dessa dissertação.

A Segunda Parte desse trabalho é composta, portanto, pelo Estudo Piloto - que consistiu em um estudo preliminar para definição do protocolo de entrevistas e para 
elaboração das categorias iniciais de análise - e pela Pesquisa propriamente dita. Abrimos a seção a partir da descrição do Método (empregado tanto no Estudo Piloto quanto na Pesquisa), em seguida apresentamos o Estudo Piloto e, por fim, a Pesquisa. 


\section{Considerações Preliminares}

Até agora, buscamos embasar nossa hipótese de que o processo de valorização da língua estrangeira é um valioso suporte para seu aprendizado. Através de discussões sobre a importância do estudo da língua inglesa na atualidade, seu ensino e aprendizagem em escolas de idiomas e as características dos aprendizes adultos - suas dificuldades e motivações procuramos entender como é possível construir não só conhecimento linguístico, mas também valores centrais que possam auxiliar os aprendizes adultos em seu caminho no processo de aquisição do novo idioma.

Além disso, meditando incidentalmente sobre a formação dos professores e sobre seu trabalho nos cursos livres de idiomas, esperando ter propiciado, ao menos em parte, material para futura reflexão e futuros estudos, colaborando com a produção do conhecimento e enriquecendo o estado da arte em nossa área. 


\section{SEGUNDA PARTE}

\section{Objetivos da Pesquisa}

Os objetivos desse trabalho são: entender as motivações que levam os alunos a procurar um curso de inglês, ligadas aos interesses - no sentido piagetiano; entender suas metas em relação ao novo conhecimento, ou seja, quais são suas projeções futuras; acessar seus sentimentos em relação ao contato com a língua e com os falantes da língua e, finalmente, relacionar interesses (combustível, energética) para o estudo do idioma inglês e valores/valorações (qualidade do combustível) ao sucesso (no sentido de suportar o desconforto) na construção do novo conhecimento e à definição daquelas metas.

\section{Método}

O método escolhido para essa pesquisa consistiu na coleta de dados por meio de entrevistas com alunos de uma escola de idiomas de médio porte, na cidade de São Paulo, cujo curso oferece um tipo de metodologia diferente da metodologia tradicional, que será explicada mais adiante. As entrevistas foram gravadas com autorização dos participantes e feitas com base na Entrevista Clínica Piagetiana, descrita por Piaget no capítulo intitulado Os problemas e os métodos, em seu livro A Representação do Mundo na Criança (1926) e que será mais bem detalhada adiante.

\subsection{Participantes}

Os participantes foram recrutados voluntariamente em uma escola de idiomas de médio porte, na cidade de São Paulo. Foram entrevistados alunos adultos, com idades entre 20 e 57 anos de idade, de ambos os sexos.

\subsection{Local}

Trata-se de uma franquia de escolas de inglês de médio porte ${ }^{12}$, na cidade de São

\footnotetext{
${ }^{12}$ Até a data da conclusão deste trabalho, a franquia contava com 19 escolas em todo o Brasil.
} 
Paulo, onde os cursos - intensivos - são voltados para o público adulto e têm duração de 18 meses. Além disso, as aulas não acontecem em horários fixos, mas são marcadas pelos alunos.

A escola selecionada para as entrevistas localiza-se em região central, ao lado de uma estação de metrô, próxima a grandes avenidas, e recebe um público que, em grande parte trabalha nas imediações.

O curso é dividido em quatro módulos e há, basicamente, cinco tipos de aula: aulas de "unidade", cujo foco é gramatical, aulas de "conversação", cujo foco é na comunicação oral e no desenvolvimento de habilidades auditivas, aulas de "review", para revisar algum ponto gramatical, "special classes", aulas extra-curriculares, que podem acontecer dentro ou fora da escola e "oral check", aulas de apresentação oral, na qual sugere-se um tema a ser desenvolvido pelo aluno, quando estudantes no último módulo.

Os alunos só podem assistir a uma aula de gramática por semana (para estudarem apenas um ponto gramatical por semana e terem tempo de fazer todas as tarefas relacionadas àquele ponto), mas as revisões e conversações têm frequência livre.

O ingresso na escola se dá através de entrevista com a assessoria de marketing, que explica a estrutura e o funcionamento do curso. Após matrícula, o estudante deve, ainda, marcar uma aula introdutória, com um professor, que repete as informações da assessoria de marketing e esclarece dúvidas quanto à metodologia das aulas. Como se trata de um curso bastante rápido, os alunos têm tarefas diárias: ouvir os áudios da lição semanal, cinco vezes cada áudio - todos os dias - e fazer as tarefas gramaticais.

Na primeira aula, costuma-se perguntar o que os motivou a estudar inglês e por que optaram por aquela escola. A maioria declara razões profissionais e a opção pelo curso se explica pelas características essenciais do mesmo: rapidez e flexibilidade. Porém, já na aula de introdução é preciso deixar bem claro que rapidez não significa pressa e flexibilidade não significa falta de tempo: é imprescindível ter tempo para o estudo e disponibilidade para a prática.

\subsection{Procedimentos para coleta e análise dos dados}

As entrevistas aconteceram nas dependências da própria escola e foram gravadas, com autorização dos participantes. Após realização, as entrevistas foram transcritas e analisadas de acordo com os princípios básicos da Entrevista Clínica de Piaget, sobre a qual falaremos a seguir.

Em A representação do mundo na criança (1926), Piaget propõe-se a estudar as 
representações de mundo que surgem espontaneamente nas crianças, mais especificamente, sobre a questão da realidade e a da causalidade. Diferentemente dos trabalhos anteriores que tratavam da forma e do funcionamento do pensamento infantil, Piaget tencionava analisar o conteúdo desse pensamento. Para isso, já no capítulo introdutório, expressa uma preocupação com o método a ser utilizado para essa investigação, pois a forma e o funcionamento do pensamento são passíveis de observação quando a criança está em contato com os adultos ou com seus pares, enquanto o conteúdo pode ou não mostrar-se, dependendo da própria criança ou do objeto de representação. Piaget rejeita o método dos testes e o da observação pura, optando pelo método clínico, mas sem antes mostrar os prós e os contras de cada um:

Quanto aos testes, submeter as crianças a provas organizadas, com perguntas idênticas para todas, feitas sob as mesmas condições, forneceria o benefício das estatísticas, que são úteis, mas trazem resultados brutos - interessantes para a prática, porém de pouca ajuda para a teoria, pela falta de contextos satisfatórios. Além disso, há o risco de falsear a orientação do pensamento da criança.

Quanto à observação pura, um dos maiores empecilhos seria o egocentrismo intelectual infantil, ou seja, "a criança não procura ou não consegue comunicar espontaneamente todo o seu pensamento" (p.9). Na interação com seus pares, a criança normalmente conversa sobre as ações imediatas, sem revelar o essencial de seu pensamento, e, na interação com os adultos, faz perguntas sem apresentar suas razões. Outro empecilho seria discernir, na fala infantil, entre a crença e a invenção.

Dessa forma, o método que engloba os recursos do teste e da observação pura é o método clínico, utilizado pelos psiquiatras com fins diagnósticos. Na entrevista clínica, podese conversar com a criança, seguindo suas ideias e explicações ao colocarem-se problemas e hipóteses, e pode-se variar as condições da entrevista, além de incluir também a observação direta, pois considera-se o contexto mental (de reflexão, de crença imediata, de jogo, de esforço, de interesse ou de fadiga).

Além disso, Piaget destaca os cinco tipos de reação observáveis através do exame clínico, para os quais o entrevistador precisa atentar e saber discernir:

- $\quad$ O "não importismo", quando a criança mostra-se aborrecida, responde qualquer coisa, sem reflexão e sem ao menos divertir-se. Parece querer apenas livrar-se do entrevistador e da situação;

- A "fabulação", ao inventar, sem muita reflexão, uma história na qual ela própria 
não acredita, por simples exercício verbal;

- A "crença sugerida", esforça-se para responder, porém a pergunta apresenta-se sugestiva ou quando quer, simplesmente, agradar o pesquisador;

- A "crença desencadeada", quando responde com reflexão, através de seus próprios recursos, sem sugestão, sendo que o interrogatório guia a resposta numa certa direção;

- A "crença espontânea", quando não necessita refletir, pois a pergunta não é nova para a criança, portanto, a resposta vem de uma reflexão anterior e original.

Dentre esse elenco de reações, as que mais interessam ao pesquisador são a "crença espontânea" e a "crença desencadeada". A primeira porque mostra uma resposta anterior à pergunta, portanto capaz de revelar a verdadeira opinião da criança sobre o assunto. A segunda é interessante na medida em que revela a orientação do pensamento infantil. A "fabulação" pode ser útil principalmente para dar algumas indicações negativas, mas tais indicações devem ser interpretadas com cautela. O "não importismo" e a "crença sugerida" devem ser evitados a todo custo. No primeiro caso, revela-se apenas a incompreensão da criança e, no segundo, percebe-se apenas aquilo que o entrevistador quis que a criança respondesse.

Apesar de idealizada para o trabalho com crianças - no intuito de acessar os conteúdos do pensamento infantil - atualmente, a entrevista clínica de Piaget extrapola esses limites e vem sendo aplicada, por exemplo, no âmbito da psicopedagogia, como procedimento de avaliação e de intervenção. Mais do que procurar respostas corretas, o método clínico procura seguir a trilha de cada resposta, entendendo como a resposta foi construída. Por isso, esse foi o método escolhido para nossa pesquisa, com adultos. 


\section{Estudo piloto: entrevistas e resultados preliminares}

O Estudo Piloto que será apresentado a seguir tratou-se, na verdade, de um estudo preliminar para definição do protocolo de entrevistas.

Foram entrevistados dez participantes, cujos resultados preliminares contribuíram não só para a definição do protocolo de entrevistas, como também possibilitaram a divulgação dos resultados preliminares dessa pesquisa em dois congressos internacionais, ambos sob a forma de pôster: $43^{\text {rd }}$ Annual Meeting of The Jean Piaget Society, com o título Studying English: values and motivation, e 16th European Conference on Developmental Psychology, com o título Studying English: values and motivation, publicado à página 78 do "Abstract Book".

\subsection{Participantes - Estudo Piloto}

Nessa fase preliminar foram entrevistados dez participantes, recrutados voluntariamente, com idades entre vinte e cinquenta e sete anos, sendo cinco do sexo feminino e cinco do sexo masculino, alguns dos quais já haviam sido alunos da entrevistadora.

\subsection{Procedimentos para a coleta de dados - Estudo Piloto}

Foram elaboradas sete questões, nos moldes da entrevista clinica de Piaget (1926), a respeito do estudo da língua inglesa, quanto a interesses, sentimentos, valorações e metas dos alunos em relação ao novo idioma. A seguir, a ordem na qual as questões apareceram na entrevista e o que se esperava acessar em cada uma delas.

1) O que você acharia de conviver com pessoas que falam outras línguas? Por quê? Explique melhor. (Refere ao contato com pessoas de outras culturas. Relacionase, por um lado, à identidade do próprio sujeito e, por outro, ao valor que esse sujeito atribui à relação com outras pessoas, de uma cultura diferente, que tem, portanto, outra forma de pensar e de ver o mundo.)

2) O que você acharia de viver em locais em que se falam outras línguas? Por quê? Explique melhor. (Aqui, permanece a ideia de relacionar identidade do sujeito ao 
valor atribuído à relação com o outro, porém colocando ênfase na cultura em si.)

3) Por que você resolveu estudar inglês neste momento? Explique melhor. (Principais motivações atuais dos estudantes, ou seja, seus interesses, ou, ainda, a energética que os impulsiona à ação.)

4) Qual é a importância da língua inglesa em sua vida? Por quê? Explique melhor. (Refere-se aos interesses, mas o foco está colocado em procurar as relações entre interesse e valor - lembrando que, para Piaget o valor é qualitativo. Apoiados nas ideias de Ryan e Deci (2000), vamos chamar de "intrínseco/a" quando - nessa relação - o idioma estiver, aparentemente, numa posição hierarquicamente privilegiada. Dito de outra forma, quando identificarmos, no sistema de valores do sujeito, um aparente lugar de destaque para o conhecimento do idioma. Além disso, refere-se também às projeções futuras, às hipóteses de uso do idioma.)

5) Qual é a utilidade da língua inglesa em sua vida? Por quê? Explique melhor. (Refere-se à práxis, à aplicabilidade do idioma, ou seja, o lugar que ele ocupa não na teoria, mas em na vida prática do sujeito. Espera-se acessar, também, as pressões sociais, "extrínsecas" - Ryan e Deci, 2000)

6) Como você se sente falando inglês? Explique melhor. (Possíveis conflitos de identidade linguística, de aceitação dos valores de outra cultura e da aceitação de si mesmo ao comunicar-se em outro idioma, ao ouvir sua voz soando diferente, enfim, sendo estrangeiro para si mesmo.)

Se você pudesse mudar alguma coisa nessa sua experiência em aprender uma língua, o que mudaria? (O valor dado à experiência e os possíveis percalços envolvidos nessa experiência, como bloqueios e frustrações.)

\subsection{Reordenação das questões - Estudo Piloto}

Após uma segunda análise, as questões foram reorganizadas de maneira a melhor atender aos propósitos da entrevista. 
Por que você resolveu estudar inglês neste momento? Explique melhor.

Qual é a importância da língua inglesa em sua vida? Por quê? Explique melhor.

Qual é a utilidade da língua inglesa em sua vida? Por quê? Explique melhor.

Como você se sente falando inglês? Explique melhor.

O que você acharia de conviver com pessoas que falam outras línguas? Por quê? Explique melhor.

O que você acharia de viver em locais em que se falam outras línguas? Por quê? Explique melhor.

Se você pudesse mudar alguma coisa nessa sua experiência em aprender uma língua, o que mudaria?

\subsection{Procedimentos para a análise de dados - Estudo Piloto}

Após a análise das respostas, optamos por nos concentrar nas quatro primeiras questões. Quanto às questões cinco e seis, houve muita interferência por parte da entrevistadora. As respostas podem ter sido prejudicadas, no sentido de terem provocado as "crenças sugeridas" - quando a pergunta apresenta-se sugestiva e produz uma resposta que serve apenas para agradar o pesquisador. A última questão não ficou clara para vários participantes e, portanto, não atendeu ao propósito inicial. Desse modo, as três últimas questões foram aproveitadas para compor a Quarta Categoria - Metas, quando os participantes mencionaram espontaneamente suas projeções futuras, suas hipóteses de uso do idioma no futuro. A princípio, acreditava-se que tais respostas apareceriam a propósito da segunda questão (Qual é a importância da língua inglesa em sua vida? Por quê? Explique melhor), porém essas projeções apareceram espontaneamente, ao longo da entrevista.

Quanto à primeira questão (Por que você resolveu estudar inglês neste momento? Explique melhor), apesar de conter a expressão "neste momento", trouxe, em todos os casos, os motivos que haviam levado o aluno a procurar o curso, por isso acabou sendo alocada como categoria 2 (motivação - valorações passadas).

As respostas foram analisadas quanto à tendência geral dos participantes e em termos de suas valorações e interesses. Para tanto, as regularidades encontradas nas respostas foram agrupadas e, a partir desse trabalho, criadas categorias de análise apresentadas a seguir. 


\subsubsection{Categorias de análise - Estudo Piloto}

De acordo com Piaget (1964/2007), os adultos estariam classificados, teoricamente, no período operatório formal. Isso significa como já exposto anteriormente, ter uma inteligência à segunda potência, conferindo-lhes a capacidade de, por exemplo, criticar sistemas, propor novos sistemas, criar teorias, tecer hipóteses, ter programas de vida e planejar o futuro. Nossos alunos estão nesse período, em que o possível está além de suas vidas presentes.

As respostas mostraram, em geral, os adultos fazendo uma análise de seu passado e presente para poder fazer projetos futuros. Do ponto de vista afetivo, corresponde a como os interesses desses adultos produziram ou estão produzindo valorizações em relação ao idioma e quais suas hipóteses para uso do novo conhecimento.

Dessa forma, devido a essas regularidades nas respostas - com algumas exceções - as categorias apresentaram uma característica marcadamente temporal. Mesmo a categoria sentimentos, cujo foco é evidentemente afetivo, refere-se a sentimentos em relação ao contato com a língua no presente.

Primeira Categoria (Importância e Aplicação): valorizações presentes - refere-se ao uso que o participante faz do conhecimento linguístico no momento presente, o lugar que o idioma ocupa na vida desse sujeito. Dividida em duas subcategorias. Níveis de 1 a 3 , sendo 1 o "menos desejável" e 3 o "mais desejável" em termos de valorizações no sentido piagetiano.

Segunda Categoria (Motivação): valorizações passadas - refere-se à energética que moveu o entrevistado ao estudo da língua inglesa. Níveis de 1 a 3 , sendo 1 o "menos desejável" e 3 o "mais desejável" em termos de valorizações.

Terceira Categoria (Sentimentos): valorizações afetivas - refere-se aos sentimentos dos participantes em relação ao contato com a língua, ao uso da língua, à aceitação dessa língua. Níveis de 1 a 3, sendo 1 o "menos desejável" e 3 o "mais desejável" em termos de valorizações.

Quarta Categoria (Metas): valorizações futuras - refere-se às projeções futuras, às hipóteses de possível uso do idioma. Níveis de 1 a 3, sendo 1 o "menos desejável" e 3 o "mais desejável" em termos de valorizações. 


\subsubsection{Análise dos dados e discussão - Estudo Piloto ${ }^{13}$}

Primeira Categoria: SUBCATEGORIA IMPORTÂNCIA (valorizações presentes)

Abaixo, apresentamos os resultados referentes à questão "Qual é a importância da língua inglesa em sua vida? Por quê? Explique melhor".

\section{NÃO É IMPORTANTE - 0\%}

\section{PARCIALMENTE IMPORTANTE - 0\%}

3. IMPORTANTE - 100\% (prioridade, muito importante, fundamental, útil, essencial)

Quanto à subcategoria importância, a totalidade dos participantes considerou o idioma algo importante. Tal fato pode apontar, como já mencionado anteriormente, para a tendência social de elevação do idioma, por uma crença na importância de se aprender inglês. Apesar de todos terem enfatizado a importância, como sabemos, cada participante tem motivos mais ou menos pessoais para fazer essa apreciação.

Na teoria de Piaget, a necessidade de adaptação produz um desequilíbrio que será resolvido tanto cognitiva quanto afetivamente. Do ponto de vista afetivo, a energética (interesses) empregada organiza-se num sistema hierárquico de valores. Quanto mais "qualidade" tiver essa energética, mais bem posicionado estará na escala pessoal de valores do sujeito.

Na teoria de Ryan e Deci (2000), atribuir importância deve ser derivado de altas motivações, porém a origem dessas motivações pode ser intrínseca (da propensão natural à aprendizagem) ou extrínseca (de pressões externas).

Tentaremos, a partir de mais dados, encontrar evidências de motivações intrínsecas, equivalentes às valorizações hierarquicamente mais centralizadas.

\section{Primeira Categoria: SUBCATEGORIA APLICAÇÃo.}

A seguir, podemos observar os resultados referentes à questão "Qual é a utilidade da

\footnotetext{
${ }^{13}$ A nomeação das categorias é geralmente passível de críticas, na medida em que o nome escolhido é arbitrário e nem sempre representa fielmente a ideia categorizada.
} 
língua inglesa em sua vida? Por quê? Explique melhor".

1. USO TEÓRICO - 20\% (não aplica em nada atualmente)

2. USO INSTRUMENTAL - 40\% (leitura: pesquisa acadêmica, artigos científicos, e-mails)

3. USO COMUNICATIVO - 40\% (comunicação oral: treinamentos profissionais, interação com pessoas no trabalho ou socialmente)

Lembrando que todos os participantes responderam ser importante aprender inglês, porém vinte por cento declarou não aplicar o conhecimento no momento.

Acreditamos que valorizações mais altas propiciariam uma tendência à aplicação - se houve procura pelo conhecimento é porque havia certa demanda. Para esses participantes, provavelmente o valor atribuído à língua deve estar numa posição mais "periférica" em relação aos outros participantes.

Para os participantes que fazem uso oral da língua, ainda que por motivações extrínsecas, acreditamos que a valorização tende a estar mais centralizada na escala pessoal, porque o contato com outras culturas e identidades deve propiciar melhora na qualidade afetiva para que o sujeito possa aguentar esse contato e diminuir possíveis angústias.

O uso instrumental também não é o desejável em termos de aquisição do conhecimento e construção de boas valorizações, pois propicia bem menos oportunidades de trocas culturais.

Segunda Categoria: MOTIVAÇÃO (valorizações passadas)

Abaixo, temos os resultados referentes à questão "Por que você resolveu estudar inglês neste momento? Explique melhor".

1. NECESSIDADE ABSTRATA - 10\% (crença na língua universal: obrigação de estudar inglês)

2. NECESSIDADE PRÁTICA - 60\% (demanda profissional: ajuda a conseguir bons empregos, atualizar-se na carreira e nos estudos, exigência no trabalho)

3. NECESSIDADE INTRÍNSECA - 30\% (gosta da língua: sempre quis estudar, vontade de estudar, viagens) 
Quanto à categoria motivação, obtivemos $30 \%$ de respostas que apontam para uma tendência natural ao aprendizado - tendências mais intrínsecas e valorizações mais centrais, portanto mais desejáveis no processo de ensino-aprendizagem.

Dez por cento declarou, porém "obrigação" de ter o conhecimento, revelando uma orientação claramente extrínseca, oriunda de pressões externas, provavelmente das crenças sociais.

A maioria - 60\% - declarou interesses que se ligam a necessidades práticas.

Acreditamos que, quando a energética para a ação provém de uma necessidade prática, o valor também tende a ser mais central na escala pessoal, na medida em que a necessidade prática é emergente e deve levar ao uso, consequentemente voltamos à ideia de uma melhora na qualidade afetiva para que o sujeito possa aguentar o contato com a língua estrangeira.

Terceira Categoria: SENTIMENTOS (valorizações afetivas)

Abaixo, temos os resultados referentes à questão "Como você se sente falando inglês? Explique melhor".

1. SENTIMENTOS NEGATIVOS - 30\% (ruim, estranho, ridículo)

2. SENTIMENTOS AMBIVALENTES - 20\% (perdida, mas é legal / vergonha, mas é legal)

3. SENTIMENTOS POSITIVOS - 50\% (bem, muito bem, orgulhoso, rica)

Quanto à categoria sentimentos, os sentimentos positivos mencionados - sentir-se bem, rico ou orgulhoso - denotam alta valorização afetiva, propiciando maior persistência no estudo e maior resistência a dificuldades e angústias no contato com a língua.

Ao contrário, sentimentos negativos, como vergonha, de baixo valor na escala afetiva, tendem a enfraquecer o contato, pois, na tentativa de evitar a angústia ou o problema, o sujeito tende a se isolar, desenvolvendo bloqueios. Sentimentos ambíguos parecem ser também mais "periféricos" na escala de valores, visto que, de acordo com Ryan e Deci (2000), aquilo que é mais extrínseco é também menos estável. 
Quarta Categoria: METAS (valorizações futuras)

Era esperado que aparecessem como resposta à segunda questão: "Qual é a importância da língua inglesa em sua vida? Por quê? Explique melhor". Porém, apareceram espontaneamente, ao longo da entrevista.

Abaixo, temos os resultados:

1. META PROFISSIONAL - 60\% (trabalho, profissão, congresso, treinamento, concorrer a uma vaga de emprego)

2. META SOCIAL- 30\% (fazer intercâmbio, visitar parentes)

3. META PESSOAL - $10 \%$ (morar no exterior)

Quanto à categoria metas, a princípio, todas se referem a interesses que podem estar em posições privilegiadas na escala pessoal de valores, pois são hipóteses, projetos futuros. Porém, aquelas que se referem claramente a possibilidade de trocas entre culturas - como as metas pessoais e sociais - são as mais desejáveis por serem aquelas afetivamente mais fortalecidas, nas quais há mais qualidade energética, podendo propiciar ao sujeito maior resistência e persistência.

Ao fim dessa análise preliminar, podemos destacar alguns fatores que propiciariam maiores valorações afetivas, ou seja, valores hierarquicamente privilegiados em relação ao conhecimento do idioma: seu uso comunicativo, necessidades práticas ou intrínsecas, sentimentos positivos em relação à língua e metas sociais e pessoais, por estarem todos mais relacionados às possibilidades de contato direto com o idioma e de trocas culturais. 


\section{Considerações sobre o Estudo Piloto}

Para Piaget (1954), afetividade e desenvolvimento cognitivo estão integrados de modo que um depende do outro. A afetividade, vista como energética, regula o interesse na interação com o objeto de conhecimento. Ainda, a coordenação desses interesses forma um sistema pessoal de valores, organizados hierarquicamente.

Procuramos mostrar, no Estudo Piloto, que pode haver conflito na dinâmica entre interesses, valores e motivações, especialmente porque nos referimos a uma língua, devido à sua natureza e papel no desenvolvimento psicológico.

Além disso, enfatizamos a grande importância do Estudo Piloto, cujos dados acabamos de examinar, para definição do procedimento de entrevistas - na elaboração, modificação e rearranjo das questões - e para a criação das categorias iniciais de análise também na elaboração e modificação dessas. Os primeiros dados colhidos no Estudo Piloto foram, portanto, ponto de partida para reflexão, discussão e preparação dos procedimentos de entrevistas e categorias de análise posteriormente adotados na Pesquisa, apresentada em seguida. 


\section{Pesquisa}

No intuito de acessar motivações, interesses e valores (no sentido piagetiano), sentimentos e metas dos estudantes adultos em relação ao conhecimento da língua inglesa, foram efetuadas entrevistas, nos moldes da Entrevista Clínica Piagetiana, já descrita anteriormente.

Os referidos depoimentos foram gravados nas dependências da própria escola, em horário combinado com os voluntários, que receberam todas as informações a respeito da pesquisa e concordaram em assinar um Termo de Compromisso (TCLE, vide anexos) em duas vias, recebendo uma cópia deste, também assinado pela pesquisadora. A própria pesquisadora colheu todos os depoimentos, os quais, após realização, foram transcritos e examinados de acordo com o embasamento teórico.

\subsection{Participantes}

Participaram desta etapa vinte alunos de uma escola de idiomas de SP, com idades entre vinte e quarenta e um anos de idade, dez do sexo feminino e dez do sexo masculino, recrutados voluntaria e aleatoriamente, com a única condição de nunca terem sido alunos da entrevistadora, para que se pudesse evitar, na medida do possível, sentimentos ou opiniões pré-concebidos a respeito da pesquisadora.

Não foram selecionados participantes em nível inicial. Todos estudavam no mínimo no nível intermediário da escola, o que equivale a dizer que estavam pelo menos no segundo módulo (de quatro), estudando há aproximadamente seis meses na escola ou já tendo estudado anteriormente em outros locais. E também já haviam passado pela experiência de ao menos uma avaliação escrita.

Para fins de análise, os voluntários estão identificados como F, para o sexo feminino e M, para o sexo masculino e numeramos de 1 a 10 (ou seja, F1, F2, F3... M1, M2...). A seguir, relacionamos suas idades e profissões.

F1: 25, Estudante de Farmácia

F2: 26, Farmacêutica

F3: 41, Encarregada de Departamento Pessoal (Graduação em Psicologia)

F4: 25, Professora de Física

F5: 20, Estagiária de TI (Tecnologia da Informação) 
F6: 24, Estudante de Engenharia Química

F7: 24, Agente de Viagens

F8: 26, Nutricionista

F9: 27, Designer Gráfica

F10: 24, Relações Públicas

M1: 25, Securitário

M2: 38, Gerente de Lotéricas (Graduação em Jornalismo)

M3: 23, Consultor de Vendas

M4: 26, Engenheiro

M5: 24, Estudante de Farmácia

M6: 31, Bancário

M7: 38, Técnico em Radiologia

M8: 28, Assistente Tributário

M9: 31, Contador

M10: 24, Analista de Sistemas

\subsection{Procedimentos para coleta de dados}

Foram elaboradas onze questões a respeito do estudo da língua inglesa. A seguir, a ordem na qual as questões aparecem na entrevista e o que se esperava acessar em cada uma delas.

\section{Por quê você está estudando inglês?}

Partindo de nossa hipótese de que, atualmente, há uma demanda social para se aprender inglês, fazendo desse conhecimento "obrigatório", na visão de algumas pessoas, resolvemos investigar o impacto dessa necessidade no aprendizado da língua inglesa.

Sabemos, através de Piaget, que o sujeito move-se a aprender qualquer coisa por uma necessidade de adaptação ao mundo. Estamos cientes, também, da importância da afetividade nesse movimento adaptativo. Os interesses de cada sujeito ocupam um papel fundamental em suas escolhas e, através da qualidade energética disponibilizada pelo sujeito, ocorre a construção de uma hierarquia com valorização afetiva (sistema de valores).

Essa pergunta pretende trazer à tona portanto, o desequilíbrio, a demanda, a motivação inicial (intrínseca ou extrínseca, de acordo com Ryan e Deci, 2000) que levou o 
sujeito a procurar "sua readaptação ao mundo", pelo aprendizado da língua estrangeira. Analisada cuidadosamente, queremos ir além e acessar também a afetividade, ou seja, a energética envolvida na escolha de se aprender inglês. Essa questão liga-se à próxima.

\section{Qual é a importância desse conhecimento na sua vida?}

Como nosso foco está nos interesses e na construção de valores, é vital investigar a importância atribuída ao conhecimento do idioma pelo próprio sujeito. Queremos descobrir se tal importância está mais ligada a seus interesses pessoais (mais intrínseca) ou às crenças na relevância social da língua estrangeira (mais extrínseca). Apoiados nas ideias de Ryan e Deci (2000), vamos chamar de "intrínseco/a" quando o idioma estiver, aparentemente, numa posição hierarquicamente privilegiada, quando identificarmos, no sistema de valores do sujeito, um aparente lugar de destaque para o conhecimento do idioma. Essa pergunta liga-se à primeira.

\section{Como tem sido sua experiência com o inglês?}

Refere-se aos sentimentos dos participantes em relação ao contato com a língua e liga-se à questão 7. Pode revelar obstáculos e dificuldades que o aluno tem ou acredita ter.

Aproveitamos para salientar que há uma distinção entre afetividade e sentimentos, de acordo com a teoria piagetiana - "Afetividade é o aspecto energético presente em toda conduta: é a afetividade que atribui um valor às atividades e regula a energia. Os sentimentos constituem o aspecto energético de condutas bem determinadas." (Freitas, 2003:99)

4. Por quê escolheu estudar nesta escola, com este método de ensino? Como você normalmente estuda? Como é sua rotina de estudos? Que horas estuda? Que materiais usa?

Com esse conjunto de perguntas, espera-se avaliar três aspectos:

a) o quanto de energia - no sentido de esforço, no caso - o entrevistado costuma empregar / disponibilizar para o estudo;

b) que tipo de materiais ele usa (quando usa) para complementar o estudo e se esses materiais favorecem a reflexão;

c) como se fez a escolha da escola. 
Tais aspectos ligam-se às valorizações dos aprendizes em relação ao próprio trabalho com a língua, no sentido de "encaixar o estudo em sua vida". Queremos entender qual posição a atividade de estudar inglês ocupa na vida do sujeito, pois imaginamos que valorações mais centrais também refletem posições mais centrais. Complementa a questão 8.

\section{Já estudou ou estudaria outra língua?}

Deseja-se avaliar a valorização do conhecimento de línguas em geral, além de possíveis sentimentos (ou entraves) de experiências linguísticas anteriores. Quer dizer, estudar línguas e, consequentemente, colocar-se em contato com outras culturas e formas de pensar configura-se como uma tendência para o entrevistado? Possíveis experiências anteriores foram bem-sucedidas? Por quê? Complementa as questões 3 e 7.

\section{Onde você aplica o conhecimento de inglês?}

Pretende-se avaliar o uso real que o entrevistado faz do conhecimento linguístico no presente e / ou projeta para o futuro. Relaciona-se à necessidade geradora do desequilíbrio, por isso importa saber se há realmente uma aplicação prática que justifique o estudo e propicie a manutenção do contato entre o sujeito e a língua, ou se a decisão de estudar partiu da crença na importância de se aprender um idioma estrangeiro e há uma aplicação apenas difusa. Complementa as questões 1 e 2 (sobre motivação), mas também será utilizada para avaliar as metas (questões 10 e 11).

\section{Como você se sente falando inglês?}

A "dependência da eloquência", ou seja, da habilidade de falar - adquirida em língua materna ao longo dos anos, representando segurança e poder - está entre as dificuldades de aprendizagem de língua estrangeira citadas por Santana (2008). Além disso, falar é uma atividade de produção, envolvendo muitas variáveis (pronúncia, entonação, estrutura, trocas com o outro, etc.), fazendo desta uma atividade bastante árdua para grande parte dos aprendizes, muitas vezes provocando embaraço e frustrações.

Aqui, procuramos relação entre sentimentos e valores. Nossa hipótese é de que valores mais centrais quanto ao idioma refletem sentimentos mais favoráveis ou mais "positivos". Estamos, portanto, na contramão do Filtro Afetivo, pois pensamos que a boa 
qualidade do combustível empregado no aprendizado de línguas (o valor) é que se traduz em sentimentos favoráveis, e não que os sentimentos são as barreiras para o aprendizado. Essa pergunta liga-se à de número 3.

\section{Você prefere falar, ler, escrever ou ouvir coisas em inglês? Coloque em ordem.}

A ordem de preferência da prática das habilidades no idioma estrangeiro pode ser revelador da energética disponível pelo sujeito para o aprendizado. Acreditamos que atividades de produção (falar e escrever), por demandarem mais energia, podem estar ligadas a valorizações mais centrais. Será complementada pela pergunta de número 4 .

\section{Estudar inglês o fez se aproximar mais de sua língua nativa, o português?}

\section{Como?}

Deseja-se investigar, aqui, os tipos de relações linguísticas feitos pelos aprendizes: se eles "pensam linguisticamente"; se refletem sobre os aspectos inerentes às línguas; se generalizam o conhecimento linguístico de um idioma para o outro; se há uma relação de apoio ou de exclusão entre as línguas; quando existe aproximação, se esta se dá ao nível estrutural ou ao nível semântico; se há menção à maior valorização de uma das línguas em detrimento da outra; se há menção à valorização linguística de modo geral, etc. Respostas a essa pergunta serão analisadas à parte, e talvez venham a lançar luz em outras questões.

\section{A experiência de estudar inglês mudou alguma coisa na sua vida ou em você?}

Trata-se das percepções ou impressões do participante quanto ao impacto desse conhecimento em sua vida. Imaginamos que, se o novo conhecimento foi ou está progressivamente sendo incorporado sua à vida, inevitavelmente haverá mudanças (cognitivas, sociais, pessoais) e, portanto, aprendizado (adaptação). Se, por outro lado, o entrevistado não percebe nenhuma mudança, talvez lhe falte se perguntar: "o que posso (ou quero) fazer com isso?"

Aqui, pretende-se revelar não só em que o participante tem aplicado seu novo conhecimento, mas também sua capacidade de enxergar um potencial de aplicação. Liga-se diretamente à próxima pergunta. 


\section{Como você se vê no futuro com o conhecimento em inglês?}

Almeja-se detectar se há clareza nas projeções futuras, quanto aos objetivos em relação ao conhecimento linguístico. Acreditamos que, quando a necessidade de aprender o idioma foi gerada pela crença em sua importância social (motivação extrínseca), as projeções futuras tendam a ser mais difusas, hipotéticas, ou seja, não existirá um objetivo claro para seu uso e aplicação, colocando-se em risco até mesmo a manutenção das habilidades a ela relacionadas.

Consideramos ser uma das vantagens dos adultos, por estarem no estágio das operações formais, ter a capacidade de planejar e traçar metas, por isso a falta dessas pode indicar valorizações menos centrais ou obstáculos enfrentados durante a experiência de estudar. Além do mais, essa questão também deve revelar a (des)crença na própria capacidade de sucesso.

\subsection{Procedimentos para a análise de dados}

Após transcritos, os depoimentos foram convertidos em quatro Quadros. Os dois primeiros, numerados de F1 a F10, correspondem às respostas femininas e os dois seguintes, numerados de M1 a M10, mostram as respostas masculinas.

Procurou-se encontrar regularidades nas respostas para, em seguida, classificá-las e representá-las por cores. Em muitos casos, houve dúvidas quanto à melhor classificação, dado que os participantes responderam a perguntas "abertas" e puderam se expressar livremente, fornecendo respostas passíveis de mais de um enquadre. Portanto, para fins de se elaborar tabelas com os resultados, foi considerado todo o conteúdo da entrevista, buscando a tendência mais forte do entrevistado e dessa, forma, escolhendo apenas uma classificação para cada resposta. No momento da análise aprofundada será possível consideraremos as respostas em sua totalidade, comentá-las e justificar nosso posicionamento.

Em seguida, as respostas foram alocadas em quatro categorias de análise: Motivação, Sentimentos, Valorizações e Metas. Depois, foram criadas Tabelas de Frequência, representando, em porcentagens, os resultados obtidos.

$\mathrm{Na}$ sequência, explicitaremos as possíveis formas de leitura e interpretação dos quadros. 


\subsubsection{Leitura dos Quadros}

Consistem em uma síntese das transcrições das entrevistas e foram confeccionados de modo a oferecer uma visão geral dos principais pontos abordados nesse trabalho (motivações, necessidades, interesses, valores, metas, sentimentos, etc.). Podem ser lidos na horizontal ou na vertical. A leitura horizontal implica na evolução dos argumentos dos participantes, desde as motivações até as metas. A leitura na vertical fornece um comparativo entre as respostas dos entrevistados. Os quadros estão disponíveis na seção Anexos.

A partir das cores, podemos identificar as áreas críticas - por exemplo as que se referem às dificuldades encontradas pelos alunos em sua experiência com o idioma - e as áreas relacionadas às tendências intrínsecas (mais desejáveis). Temos, portanto, um mapeamento dos principais assuntos do presente trabalho.

Em seguida, detalharemos o significado de cada cor e faremos uma leitura prévia dos painéis. As análises completas estarão na seção 5.4. Análise dos dados e discussão.

Observação: aqui aparece apenas a nomenclatura das cores, em caso de dúvidas, conferir a cor na própria legenda dos quadros anexos.

\section{a) Marrom: Relação com o mundo profissional e uso instrumental da língua}

Nas questões 1, 2, 6, 10 e 11 (motivações, crença na importância, aplicação do idioma, mudanças e metas, respectivamente), a cor marrom representa as relações entre o trabalho e os pontos acima mencionados.

Para as questões 1 e 2 (motivações e crença na importância), atribuiu-se a cor marrom quando o participante, mesmo tendo citado várias motivações e crenças, deixou a ênfase recair sobre o trabalho - de acordo com o conteúdo de seu depoimento - ou quando ele mesmo estabeleceu uma ordem de motivos ou de importância.

Para a questão 6 (aplicação), a cor marrom indica "uso instrumental" da língua no trabalho, ou seja, uso do idioma principalmente para leitura (para o "uso comunicativo" no trabalho - quando o participante comunica-se também oralmente - foi escolhida a cor verde).

Para as questões 10 e 11 (mudanças e metas), indica a percepção de mudanças no ambiente de trabalho e o estabelecimento de metas essencialmente voltadas à sua evolução no trabalho ou na carreira. 


\section{b) Magenta: Crença na universalidade da língua inglesa}

A crença na "universalidade da língua" liga-se à "crença na obrigação em conhecêla" - uma das hipóteses de nosso trabalho, tendo sido tratada na primeira parte, no embasamento teórico.

Esperava-se que fosse aparecer - como de fato ocorreu - nas respostas às duas primeiras perguntas, indicando que a crença na língua inglesa como uma língua "universal" pode ser a motivação para o estudo ou constituir a importância deste.

Consideramos "crença na universalidade" quando as respostas, mesmo contendo várias motivações e justificativas de importância para o estudo, mais tarde, no decorrer da entrevista, não mostraram aplicações e metas objetivas quanto ao conhecimento do idioma.

\section{c) Azul celeste: Tendências intrínsecas ou pessoais}

Nas questões 1 e 2 (motivação e crença na importância), a cor azul celeste salienta a motivação intrínseca para o aprendizado, bem como a atribuição de uma importância também de origem intrínseca.

Nas questões 10 (mudanças), considerou-se tendências intrínsecas ou pessoais os relatos em primeira pessoa quanto à percepção dos participantes de evolução de si mesmos.

$\mathrm{Na}$ questão 11 (metas) considerou-se metas pessoais os depoimentos dos participantes sobre planos relacionados prioritariamente à própria evolução em relação ao idioma, por exemplo, continuar o estudo ou viajar para praticar o idioma.

A escolha do termo "tendências" remete à afetividade envolvida no processo de aprendizagem, conforme se verá na seção 5.4.2.Categoria Sentimentos.

\section{d) Verde: Tendências ou atitudes mais desejáveis para o aprendizado}

Nas questões 3, 4, 5 e 7 (experiência, estudo, outras línguas, habilidade oral) exploramos as tendências ativas e as iniciativas dos alunos para a obtenção de melhores resultados.

Em 4 e 7 (estudo, habilidade oral), procuramos indícios de tendências mais ativas em relação ao uso e aplicação do conhecimento linguístico, como engajamento no estudo e busca de materiais apoio - dicionários, gramáticas, exercícios extra - e sentimentos de segurança quanto à prática oral do idioma. 
Em 3 e 5 (experiência, outras línguas), pesquisamos indícios de tendências mais desejáveis como relatos de experiências produtivas e interesse em línguas de um modo geral.

$\mathrm{Na}$ questão 5, o verde corresponde aos participantes que já estudaram outra(s) língua(s) e demonstraram interesse em prosseguir nesse estudo.

\section{e) Amarelo: Ambivalência}

Nas mesmas questões anteriores (de 3, 4, 5 e 7), a cor amarela corresponde ao que nomeamos "ambivalência", que seriam "tendências mistas".

Na questão 3, sobre a experiência de estudar inglês, ambivalentes são as respostas que, apesar de otimistas, citam algum tipo de dificuldade.

$\mathrm{Na}$ questão 4, quanto ao estudo e uso de materiais, foi considerada ambivalente a utilização de materiais como filmes, músicas e dicionários bilíngues, pois, apesar de serem uma ótima fonte motivacional, de entretenimento, de prática e de informação, não se pode avaliar o quanto de reflexão linguística foi realmente produzido.

Quanto à questão 5, sobre desejo de aprender outras línguas, a ambiguidade refere-se ao alunos com "médio interesse" em línguas: aqueles que (hipoteticamente) estudariam algum outro idioma, ou aqueles que já estudaram mas citam dificuldades ou têm pouco interesse em se dedicar ao estudo formal.

$\mathrm{Na}$ questão 7, quanto à avaliação de sua própria competência oral, a ambivalência fica por conta também de respostas por um lado otimistas, mas que mencionam algum tipo de dificuldade ou sentimentos como vergonha, timidez, nervosismo, medo, constrangimento.

\section{f) Vermelho: Tendências ou atitudes menos desejáveis para o aprendizado}

Ainda examinando as questões 3, 4, 5 e 7, a cor vermelha evidencia:

- relatos de experiências traumáticas ou conflituosas;

- pouco engajamento no estudo (não há procura por materiais complementares);

- uso de materiais que não necessariamente propiciam reflexão linguística (sites de tradução, por exemplo);

- $\quad$ baixo interesse ou pouca inclinação para as línguas em geral;

- $\quad$ sentimentos desfavoráveis quanto à sua própria competência oral. 


\section{g) Azul: Casual, difuso, hipotético, generalizado}

Para as questões 6, 10 e 11 (aplicação, mudanças e metas) a cor azul indica, respectivamente:

- um "uso casual”, quando não parece haver uma aplicação objetiva e constante do idioma ou quando o participante generalizou demais sua resposta ("uso em tudo");

- incertezas ou dúvidas quanto às mudanças, ou mudanças mais extrínsecas e gerais, não diretamente ligadas nem trabalho nem a si mesmos;

- $\quad$ metas pouco objetivas ou desfocadas, generalizadas.

\section{h) Azul claro: Escolha da escola}

Essa cor refere-se aos motivos de escolha da escola: método rápido, horários flexíveis, indicação de amigos ou parentes, método focado na conversação e preço (custobenefício).

Quarenta por cento dos entrevistados recebeu indicação de parentes ou amigos para estudar na escola. Esse alto índice deve-se ao fato de a escola praticamente não vincular comerciais nos meios de comunicação em massa. O marketing da empresa trabalha principalmente a partir da rede de contatos dos alunos ingressantes.

\section{i) Verde degradê: Deslocamento da zona de conforto}

Na questão 8, quando se pede para escolher entre falar, ler, escrever ou ouvir, procuramos investigar as tendências dos participantes em relação a sair ou permanecer na zona de conforto.

Num degradê do verde mais claro ao verde mais escuro, temos:

- $\quad$ Ler - habilidade geralmente mais receptiva e mais independente;

- Ouvir - geralmente receptiva, porém implica certa dependência (de compreensão dos sons, por exemplo);

- Escrever - atividade de produção (geralmente pressupõe maior esforço de reflexão), mais independente quanto à interação; 
- Falar - atividade de produção (implica vários aspectos da linguagem), de todas a mais "dependente", no sentido de requerer disposição para interagir. Portanto, é a que mais desloca o aluno de sua zona de conforto.

\section{j) Rosa degradê: Relação entre as línguas (português e inglês)}

Na questão 9 (Estudar inglês fez você se aproximar mais do português?), procurávamos acessar as relações feitas pelos alunos entre as duas línguas. Num degradê do rosa mais claro ao mais escuro, temos:

- nenhuma relação de aproximação entre as línguas;

- $\quad$ relação de superioridade / inferioridade (português é uma língua mais complexa que inglês);

- relação de aproximação gramatical ou semântica (algumas regras são válidas para ambas as línguas).

Lembramos que os Quadros estão na seção Anexos.

\subsubsection{Tabelas de Frequência}

Para a organização dos dados, optou-se pela utilização de Tabelas de Frequência, nas quais indicaremos o número de vezes que cada resposta apareceu, num universo de vinte ou de quarenta possibilidades, junto com as porcentagens equivalentes. Foram confeccionadas quatro tabelas, correspondendo às categorias de análise:

- Tabela 1: Sobre Motivações

- Tabela 2: Sobre Sentimentos

- Tabela 3: Sobre Valorizações

- Tabela 4: Sobre Metas

\subsubsection{Categorias de análise}

A partir das onze questões, foram criadas quatro categorias de análise: Motivação, Sentimentos, Valorizações e Metas. Tais agrupamentos permitem organizar as ênfases que 
foram dadas nessa pesquisa e correspondem aos principais eixos aqui trabalhados. As questões foram dispostas da seguinte maneira:

\section{Questões 1 e 2: Categoria Motivação}

As respostas referentes às motivações para o estudo do idioma e à importância desse estudo formam a categoria Motivação, na medida em que os relatos relacionam-se às "pressões" (intrínsecas ou extrínsecas) que levaram o entrevistado a procurar o estudo, e à energética que alimenta a manutenção da ação de estudar.

A discussão dessa categoria será complementadas pela questão 6, pois desejamos examinar a relação entre os motivos alegados e o real potencial de aplicabilidade do idioma na vida do estudante.

\section{Questões 3 e 7: Categoria Sentimentos}

O desenvolvimento da competência de falar é bastante problemático para alguns por abarcar diversos aspectos da língua e por estar menos sujeito ao controle - e a experiência de aprender um idioma, como já mencionamos antes, envolve afetividade (vista como energética). Por isso, acreditamos que os sentimentos relatados pelos aprendizes podem nos ajudar a acessar suas valorizações, principal objetivo da presente dissertação.

A discussão dessa categoria será complementada pela questão 5 (tendências para o aprendizado de línguas em geral) que também pode nos dar indícios sobre as valorizações, na medida em que evidencia as inclinações dos alunos para o estudo de línguas. Em última instância, conheceremos um pouco dos interesses dos alunos.

\section{Questão 8: Categoria Valorizações}

A questão 8 trata das valorizações propriamente ditas, pois acreditamos que é necessário - na construção de valores no novo idioma - que esses valores já estejam assumindo posições centrais para que o aluno demonstre uma tendência a sair da zona de conforto, aceitando a interação com o outro. Portanto, tendências mais ativas de uso do idioma, (principalmente falar), podem estar relacionadas a valores mais centralizados, permitindo ao sujeito "aguentar" a interação.

Será complementada pela questão 4 , que também receberá uma análise detalhada, 
pois se refere à energética empregada na ação de estudar.

\section{Questões 10 e 11: Categoria Metas}

A possibilidade de fazer balanços e projeções futuras dá aos adultos a capacidade de reorganização de suas atividades para extrair o melhor proveito delas. Quando se aprende um idioma, parte da tarefa é encontrar uma maneira de mantê-lo em uso, para que esteja em constante progresso e não se percam as propriedades que dependem da memória. Acreditamos que o estabelecimento de metas também pode ter correlação com os valores construídos pelo aluno em sua trajetória de aprendizado.

Será associada às questões 1 e 2, pois motivações normalmente ligam-se a metas, pelo menos quando se há clareza nessa trajetória.

Observação: A questão 9 receberá um tratamento à parte, fora das categorizações, porém gostaríamos que servisse como ponto de partida para reflexão, principalmente para os professores.

\subsection{Análise dos dados e discussão}

Exporemos, a princípio, os dados das onze questões separadamente, fazendo os devidos comentários. Em seguida, comporemos as categorias conforme explicado e examinaremos os dados dentro desses recortes.

Note-se que as respostas foram distribuídas em três ou quatro níveis, onde 1 representa o nível "menos desejável" e 3 (ou 4), o nível "mais desejável" em termos de valoração, no sentido piagetiano.

Quanto à questão 4, há 5 níveis - no que se refere à escolha da escola - porém sem hierarquia de valores.

Aqui, baseados em vinte respostas, mostraremos primeiro as porcentagens totais (respostas masculinas e femininas) e, depois, desse total, qual porcentagem equivale às respostas femininas e qual corresponde às masculinas, separadamente. 


\begin{tabular}{|l|c|c|c|}
\hline Q1. Por que você está estudando inglês? & MASC & FEM & TOTAL \\
\hline 1. Motivação extrínseca: universalidade da língua & $10 \%$ & $10 \%$ & $20 \%$ \\
\hline 2. Motivação extrínseca: mercado de trabalho & $20 \%$ & $30 \%$ & $50 \%$ \\
\hline 3. Motivação intrínseca: interesse pessoal & $20 \%$ & $10 \%$ & $30 \%$ \\
\hline
\end{tabular}

Como era previsto, a principal razão da procura pelo curso de inglês é profissional. Interessante observar que essa tendência é maior nas mulheres. Três participantes (F3, F8 e M8) que declararam motivação profissional afirmaram também, mais tarde, que não usam ou não precisam de inglês no trabalho atual. Tal fato tanto pode indicar que eles têm metas para evoluir na carreira e estão se preparando desde já, como pode estar ligado à crença na obrigação de conhecer inglês para competir no mercado de trabalho.

\begin{tabular}{|l|c|c|c|}
\hline $\begin{array}{l}\text { Q2. Qual é a importância desse conhecimento em sua } \\
\text { vida? }\end{array}$ & MASC & FEM & TOTAL \\
\hline 1. Importância extrínseca: universalidade da língua & $10 \%$ & $15 \%$ & $25 \%$ \\
\hline 2. Importância extrínseca: mercado de trabalho & $35 \%$ & $20 \%$ & $55 \%$ \\
\hline 3. Importância intrínseca: interesse pessoal & $5 \%$ & $15 \%$ & $20 \%$ \\
\hline
\end{tabular}

Mais da metade dos participantes declarou que a importância de saber inglês está ligada às exigências do mercado de trabalho, corroborando com as motivações para estudar. Porém, agora, a tendência é maior nos homens, ou seja, mesmo que a motivação para estudar não seja profissional, eles acreditam que será importante para a carreira. Note-se que o discurso da "universalidade da língua" apareceu, além do que está computado aqui, outras duas vezes (conforme se poderá observar nos painéis que contém as sínteses das entrevistas): na fala de F10 e na fala de M9, ambas em resposta à questão número 1, sobre motivação. Porém, optamos por não classificar tais respostas como "crença na universalidade da língua" por terem aparecido associadas às ideias de importância profissional ou pessoal, tendo essas últimas ideias recebido mais ênfase. 


\begin{tabular}{|l|c|c|c|}
\hline Q3. Como tem sido sua experiência com o inglês? & MASC & FEM & TOTAL \\
\hline 1. Sentimentos negativos & $15 \%$ & $5 \%$ & $20 \%$ \\
\hline 2. Sentimentos ambivalentes & $20 \%$ & $25 \%$ & $45 \%$ \\
\hline 3. Sentimentos positivos & $15 \%$ & $20 \%$ & $35 \%$ \\
\hline
\end{tabular}

Homens manifestam mais sentimentos negativos que as mulheres. Mulheres relatam mais sentimentos positivos e também mais sentimentos ambivalentes. Nos sentimentos ambivalentes, os participantes normalmente afirmam gostar da língua, mas alegam ter dificuldades com ela.

Q4. Por que escolheu estudar nesta escola, com este método de ensino? Como você normalmente estuda? Como é sua rotina de estudos? Que horas estuda? Que materiais usa?

\begin{tabular}{|l|c|c|c|}
\hline A. Escolha da escola & MASC & FEM & TOTAL \\
\hline 1. Método rápido & $5 \%$ & $15 \%$ & $20 \%$ \\
\hline 2. Custo benefício & $15 \%$ & - & $15 \%$ \\
\hline 3. Horários flexíveis & $5 \%$ & $10 \%$ & $15 \%$ \\
\hline 4. Indicação de amigos / parentes & $25 \%$ & $15 \%$ & $40 \%$ \\
\hline 5. Foco na conversação & - & $10 \%$ & $10 \%$ \\
\hline
\end{tabular}

Nota-se que a questão do tempo é importante para os entrevistados: $20 \%$ escolheu esse curso por ter menor duração que outros no mercado (18 meses) e 15\% preferiu esta escola porque pode marcar e remarcar suas aulas, flexibilizando, assim, sua agenda. Quanto aos $40 \%$ que foram indicados por amigos ou parentes, já mencionamos anteriormente que se deve ao fato de o marketing da empresa trabalhar preferencialmente com os contatos dos alunos ingressantes. O representante de marketing solicita as indicações no momento da assinatura do contrato. 


\begin{tabular}{|l|c|c|c|}
\hline B. Uso de material de apoio (além de dicionário) & MASC & FEM & TOTAL \\
\hline 1. Não usa nenhum material de apoio & $20 \%$ & $10 \%$ & $30 \%$ \\
\hline $\begin{array}{l}\text { 2. Ouve música, assiste filme ou seriado, lê livro } \\
\begin{array}{l}\text { 3. Usa gramática impressa, acessa sites de gramática ou } \\
\text { de exercícios }\end{array}\end{array}$ & $10 \%$ & $5 \% \%$ & $55 \%$ \\
\hline
\end{tabular}

O curso em questão, por suas características - intensivo, voltado para as necessidades dos adultos - requer do aluno estudo constante e realização de tarefas diárias. Ele precisa fazer todos os exercícios, inclusive os de gramática, antes de assistir às aulas. Por isso, acreditamos que estudar apenas com o material do curso (livro e CD) seja insuficiente em muitos casos, mas constatamos que apenas $15 \%$ dos alunos utiliza normalmente algum tipo de material extra. Esse fato precisaria ser repensado, através da criação de estratégias que incorporassem materiais de apoio ao cotidiano do aluno, e de modo que os professores pudessem orientá-los sobre a melhor maneira de estudar em casa.

\begin{tabular}{|l|c|c|c|}
\hline C. O que utiliza quando tem dúvidas de vocabulário? & MASC & FEM & TOTAL \\
\hline 1. Sites de tradução & $35 \%$ & $30 \%$ & $65 \%$ \\
\hline 2. Dicionário bilíngue & $5 \%$ & $15 \%$ & $20 \%$ \\
\hline 3. Dicionário monolíngue & $10 \%$ & $5 \%$ & $15 \%$ \\
\hline
\end{tabular}

Verifica-se que grande maioria prefere utilizar ferramentas rápidas - como o tradutor do Google - para sanar dúvidas de vocabulário, o que consideramos de baixa eficácia na produção de reflexão e, consequentemente, no aprendizado efetivo da língua. Considerando que todos os alunos já estão no nível intermediário da escola e, portanto já dispõem (ou deveriam dispor) de algumas estratégias de aprendizagem, inclusive de autonomia para buscar e selecionar as informações, esse dado é algo mais para se pensar. 


\begin{tabular}{|l|c|c|c|}
\hline Q5. Já estudou ou estudaria outra língua? & MASC & FEM & TOTAL \\
\hline 1. Baixo interesse & $10 \%$ & $20 \%$ & $30 \%$ \\
\hline 2. Médio interesse & $30 \%$ & $15 \%$ & $45 \%$ \\
\hline 3. Alto interesse & $10 \%$ & $15 \%$ & $25 \%$ \\
\hline
\end{tabular}

Classificamos como "médio interesse" os participantes que gostariam de estudar uma língua ou aqueles já estudaram, porém, deram mostras de uma relação ambígua com esse aprendizado. A julgar pelos adjetivos usados para descrever as línguas - bonita, cantada, forte, feia, importante, interessante, difícil, maravilhosa, charmosa, desafiadora - podemos perceber a afetividade envolvida no aprendizado de línguas.

\begin{tabular}{|l|c|c|c|}
\hline Q6. Onde você aplica o conhecimento de inglês & MASC & FEM & TOTAL \\
\hline 1. Uso eventual / casual & $20 \%$ & $15 \%$ & $35 \%$ \\
\hline 2. Uso instrumental & $20 \%$ & $30 \%$ & $50 \%$ \\
\hline 3. Uso comunicativo & $10 \%$ & $5 \%$ & $15 \%$ \\
\hline
\end{tabular}

Uso eventual / casual é a utilização esporádica do conhecimento, por exemplo para leitura de artigos científicos, ou a aplicação no lazer (ouvir música, assistir a filmes, etc.). O ponto desfavorável, nesse caso, é não ser sistematizado, pois o sujeito provavelmente não tira tanto proveito do idioma quanto poderia. Uso instrumental diz respeito à utilização do idioma principalmente para leitura. Aqui, está sempre relacionado ao trabalho. Novamente, metade dos entrevistados declara aplicar esse conhecimento no ambiente profissional. Uso comunicativo envolve comunicação oral e, em nossa pesquisa, também se relaciona ao trabalho. 


\begin{tabular}{|l|c|c|c|}
\hline Q7. Como você se sente falando inglês? & MASC & FEM & TOTAL \\
\hline 1. Sentimentos negativos & $10 \%$ & $20 \%$ & $30 \%$ \\
\hline 2. Sentimentos ambivalentes & $40 \%$ & $20 \%$ & $60 \%$ \\
\hline 3. Sentimentos positivos & - & $10 \%$ & $10 \%$ \\
\hline
\end{tabular}

Sabemos que falar, mesmo na língua materna, pode ser motivo de desconforto, já que pressupõe exposição do falante às "críticas" do ouvinte. Quando se aprende um novo idioma, a vontade de falar esbarra em inúmeros obstáculos, alguns que o próprio aprendiz se impõe. Talvez isso explique o alto índice de sentimentos ambivalentes expressados nas entrevistas. Note-se que apenas mulheres (duas) relataram sentimentos positivos em relação a falar o idioma.

Os sentimentos identificados como negativos, conforme o contexto, foram: dificuldade / travamento / vergonha / insegurança / medo de errar / constrangimento / desconforto / timidez;

Sentimentos ambivalentes: à vontade na escola, mas pressionado ou nervoso no trabalho/ às vezes sinto dificuldade, mas nos pubs converso numa boa / com meu irmão não tenho vergonha, mas com os professores fico constrangida / um pouco nervosa, mas acho que estou fazendo do jeito certo / sensação ruim, mas gratificante quando consigo falar / um pouco de medo no trabalho, mas com um nativo eu não teria medo / bem seguro, mas tenho vergonha de falar errado / parecendo um caipira porque a pronúncia não está correta, mas quando me corrigem me sinto tranquilo / um pouco difícil, mas quando monto uma frase me sinto feliz / nunca fui de ter vergonha de tentar, às vezes dá uma travada / ainda tenho que melhorar, mas acho que aprendi legal / realizado, luto contra pensar em português;

Sentimentos positivos: uma pessoa muito melhor / passando na frente dos outros candidatos. 


\begin{tabular}{|l|c|c|c|}
\hline $\begin{array}{l}\text { Q8. Você prefere falar, ler, escrever ou ouvir coisas } \\
\text { em inglês? Coloque em ordem }\end{array}$ & MASC & FEM & TOTAL \\
\hline 1. Prefere ler & $20 \%$ & $15 \%$ & $35 \%$ \\
\hline 2. Prefere ouvir & $15 \%$ & $10 \%$ & $25 \%$ \\
\hline 3. Prefere escrever & $5 \%$ & - & $5 \%$ \\
\hline 4. Prefere falar & $10 \%$ & $25 \%$ & $35 \%$ \\
\hline
\end{tabular}

Segundo os depoimentos, a maioria das mulheres prefere falar. Já a maioria dos homens, prefere ler. Escrever foi a habilidade menos votada, talvez porque, dependendo do gênero de escrita, envolva o emprego de regras formais, o que torna essa atividade mais laboriosa, sobretudo quando não se tem domínio sobre o idioma.

\begin{tabular}{|l|c|c|c|}
\hline $\begin{array}{l}\text { Q9. Estudar inglês o fez se aproximar mais de sua } \\
\text { língua nativa, o português? Como? }\end{array}$ & MASC & FEM & TOTAL \\
\hline 1. Não faz relação de aproximação & $10 \%$ & $10 \%$ & $20 \%$ \\
\hline 2. Faz relação de superioridade / inferioridade & $5 \%$ & $15 \%$ & $20 \%$ \\
\hline 3. Faz relação de aproximação gramatical ou semântica & $35 \%$ & $25 \%$ & $60 \%$ \\
\hline
\end{tabular}

A questão 9 trouxe à tona a ideia, já mencionada por Ortiz (2008), da suposta simplicidade do inglês face ao português (chamamos aqui "relação de superioridade / inferioridade"). Mesmo não tendo sido o principal objetivo da pergunta - que, na verdade pretendia acessar as relações de apoio ou de exclusão entre as línguas - foi possível verificar a existência dessa noção, visto que os participantes a mencionaram espontaneamente. 


\begin{tabular}{|l|c|c|c|}
\hline $\begin{array}{l}\text { Q10. A experiência de estudar inglês mudou alguma } \\
\text { coisa na sua vida ou em você? }\end{array}$ & MASC & FEM & TOTAL \\
\hline 1. Mudança casual & $15 \%$ & $5 \%$ & $20 \%$ \\
\hline 2. Mudança profissional & $25 \%$ & - & $25 \%$ \\
\hline 3. Mudança pessoal & $10 \%$ & $45 \%$ & $55 \%$ \\
\hline
\end{tabular}

Retomando a primeira pergunta, lembramos que as mulheres atribuíram ao aspecto profissional sua maior fonte de motivações para o estudo, porém, em se tratando da percepção de mudanças acorridas como consequência da instrução, apenas os homens relataram mudanças no ambiente profissional. Nove entre dez mulheres distinguiram mudanças no aspecto pessoal.

\begin{tabular}{|l|c|c|c|}
\hline $\begin{array}{l}\text { Q11. Como você se vê no futuro com o conhecimento } \\
\text { em inglês? }\end{array}$ & MASC & FEM & TOTAL \\
\hline 1. Meta casual & $15 \%$ & $15 \%$ & $30 \%$ \\
\hline 2. Meta profissional & $30 \%$ & $15 \%$ & $45 \%$ \\
\hline 3. Meta pessoal & $5 \%$ & $20 \%$ & $25 \%$ \\
\hline
\end{tabular}

Novamente, os homens estão mais focados em metas relacionadas ao ambiente profissional. Nota-se também um índice significativo de pessoas que não possuem ainda uma meta clara, o que também deve ser passível de reflexão e será explorado mais à frente.

A seguir, analisaremos os quatro eixos principais de nosso trabalho, investigando os dados obtidos na pesquisa - que acabamos de expor - à luz da teoria piagetiana. 


\subsubsection{Categoria Motivação}

Essa categoria foi composta a partir do agrupamento das respostas às questões 1 (Por quê você está estudando inglês?) e 2 (Qual é a importância desse conhecimento na sua vida?). Será complementada pelas respostas à questão 6 (Onde você aplica o conhecimento de inglês?). A Tabela de Frequência (tabela 1) e as porcentagens estão baseadas, portanto, num total de quarenta respostas (vinte respostas dadas à questão 1 e vinte, à questão 2). A tabela mostra primeiro as porcentagens totais (respostas masculinas e femininas juntas) e, depois, dessa porcentagem, quanto equivale às respostas femininas e quanto corresponde às masculinas, separadamente. Note-se que o algarismo entre parênteses representa o número de ocorrências de cada tipo de resposta.

(tabela 1)

CATEGORIA MOTIVAÇÃO

MASC FEM TOTAL

(20)

(20)

(40)

1. MOTIVAÇÃO EXTRÍNSECA:

$10 \%$

$12,5 \%$

$22,5 \%$

UNIVERSALIDADE DA LÍNGUA

(4)

(5)

(9)

2. MOTIVAÇÃO EXTRÍNSECA:

$27,5 \%$

$25 \%$

$52,5 \%$

MERCADO DE TRABALHO

(11)

(10)

(21)

3. MOTIVAÇÃO INTRÍNSECA:

$12,5 \%$

$12,5 \%$

$25 \%$

INTERESSE PESSOAL

(5)

(5)

(10)

Ryan e Deci (2000) definem estar "motivado" como estar "movido a fazer a algo", estar "energizado" em relação a um fim. Esse é o princípio do qual partimos na presente dissertação, formando, junto com a teoria piagetiana, um dos eixos de nosso trabalho.

A preocupação com esse tema começou logo nos primeiros anos de docência, ainda em língua portuguesa, ao se observar as diferenças de aprendizagem de um mesmo assunto 
por diferentes aprendizes. Contudo, dizer que a afetividade faz parte desse processo é lugarcomum. A verdadeira questão repousa no como lidar com isso e como ajudar nossos alunos sem ficarmos, nós mesmos, frustrados. É claro que não há uma resposta única e definitiva a essa pergunta, por isso nosso engajamento em estudar e tentar entender melhor o papel na afetividade na aprendizagem.

Nosso recorte em alguns eixos ligados à afetividade - motivação, valores, sentimentos e metas - deve-se ao terreno fértil da aprendizagem de idiomas por adultos. Considerando que a busca pelo conhecimento de uma nova língua na idade adulta é uma decisão consciente do sujeito, na medida em que é ele mesmo quem (normalmente) escolhe, organiza e negocia suas aulas, o tema da motivação pode parecer até mesmo supérfluo, pois se há procura por algo, se alguém está "movido a fazer algo", é porque existe motivação energia, força motriz que desloca os sujeitos em direção a esse algo.

$\mathrm{Na}$ verdade, pode parecer óbvio alguém desejar aprender uma língua para se comunicar. Logo, a motivação seria a possibilidade de comunicação. Então por que, no cotidiano das aulas, há tantos conflitos e frustrações?

Retomando Ryan e Deci (2000), a motivação funciona como um regulador do comportamento, e o processo regulatório é a escolha. Se há uma escolha "livre" ou, no caso do estudo de línguas, há propensão para seu aprendizado, a motivação é intrínseca. É uma motivação com maior qualidade energética. Quando procedem de pressões externas, são extrínsecas, com menos qualidade energética. Seguindo esse raciocínio, é plausível dizer que alguns conflitos derivem das próprias escolhas dos sujeitos. É diferente buscar o conhecimento de um idioma para ter um currículo melhor do que para se comunicar durante uma desejada viagem de turismo.

Para Piaget (1954), o interesse é a energética que regula o comportamento, ou seja, a interação do sujeito com o objeto de conhecimento. Se não há interesse, não há motivos para se resolver um problema. Ou melhor, se não há interesse, o problema talvez nem se coloque.

Quanto ao fator importância, esse é um elemento que normalmente se apresenta ao falarmos de motivações. Em sua teoria, Ryan e Deci (2000) explicam que atribuir importância deve ser derivado de altas motivações, por isso, em nossa primeira tabela, aglutinamos os resultados das motivações e da importância do conhecimento.

Examinando a Tabela de Frequência tendo em mente todas essas ideias, constatamos primeiro que há maiores índices de motivação extrínseca envolvidos no desejo de aprender inglês: $75 \%$ ao todo ("universalidade da língua" e "mercado de trabalho"). Podemos extrair algumas reflexões: 
- $22,5 \%$ das motivações dizem respeito à crença de que a língua inglesa é universal. A nosso ver, a problemática dessa crença consiste principalmente nas projeções futuras. A justificativa de se estudar a língua é a universalidade, mas, qual é o objetivo? Essa motivação, de todas é a mais abstrata e, em geral, os participantes não sabem explicar muito bem o que vão fazer com o conhecimento. Tal crença vem da sociedade, que, por sua vez busca uma língua universal, por todos aqueles motivos expostos na primeira parte de nosso trabalho. É uma preocupação, portanto, da sociedade, não do participante. Um exemplo disso é a entrevistada F9 (cf. painéis de entrevistas), escolhida para ser um de nossos estudos de caso. Ela respondeu "crença universal" tanto para a motivação quanto para a importância do aprendizado e, no conjunto de suas respostas, observamos três marcadas com a cor vermelha (experiência, outras línguas e habilidade oral), o que corresponde às "tendências menos desejáveis", ou conflitos.

- A "crença na universalidade" é provavelmente maior do que nossas frequências mostram (apareceu também nas falas de F10 e M9, ambas em resposta à questão número 1, sobre motivação). Era um resultado esperado na medida em que, como é uma ideia bastante difundida na sociedade, as pessoas acabam repetindo tal discurso e tomando-o como verdadeiro. E não podemos desconsiderar o fato de que o idioma, segundo depoimentos informais de vários alunos, é um dos critérios de seleção profissional em muitas empresas, multinacionais ou não, mesmo quando não é utilizado nas funções do dia-a-dia.

- Se a "crença na universalidade" vem associada a outra motivação ou o participante atribui a importância de estudar o idioma a outro aspecto profissional, por exemplo - as chances de haver conflito são menores (conferir F2, F6, F8, M9, M10), com exceção de M2, pois, mesmo declarando importância no trabalho, demonstra vários conflitos quanto à experiência de estudar, o engajamento no estudo e à competência oral.

- Não encontramos relação entre "crença na universalidade" e "aplicação casual" (questão 6). A princípio, achávamos que, pela característica de generalidade desse tipo de motivação/importância, a aplicação também seria majoritariamente 
casual, mas essa suspeita não se confirmou. De todos que deram pelo menos uma resposta "crença na universalidade", 3 fazem uso instrumental (F2, F9, M2), 2 fazem uso comunicativo (M9, M10) e 3 fazem uso casual (F6, F8, M3). Portanto, as respostas mostraram-se bastante balanceadas.

- 52,5\% correspondem às motivações por pressões profissionais. Como previsto, há grande concentração de conflitos, visto que, apesar de constituírem motivações mais concretas que a "crença na universalidade", ainda são motivações extrínsecas. Dos quinze participantes cuja motivação ou importância (ou ambas) está ligada ao aspecto profissional, sete exibem "tendências menos desejáveis", conflitos quanto à experiência, outras línguas e habilidade oral (F2, F3, F4, F5, M1, M2, M5). Porém, curiosamente, todos os relatos de experiências positivas concentram-se aqui: F1, F2, F3, F8 relatam experiências positivas. M9 e M10, não só relatam experiências positivas, mas também fazem uso comunicativo da língua. Talvez isso possa ser explicado pela Teoria da Equilibração de Piaget: quando há uma demanda que desequilibra o sujeito e o deixa em desvantagem em relação ao mundo, existe um movimento do sujeito em busca de reequilibração. Em outras palavras, a necessidade de se aprender algo para resolver um problema é força motriz para a construção do conhecimento.

- $25 \%$, o equivalente a um quarto dos entrevistados, respondeu "interesse pessoal" (gosta do idioma ou pretende viajar, conhecer pessoas e lugares novos). Essa é uma motivação intrínseca, visto que se relaciona à inclinação do sujeito para aquele tipo de aprendizado. Além disso, consideramos como intrínseca também a tendência de aprender para se comunicar, em uma viagem, por exemplo, dado o caráter de envolvimento pessoal numa situação de comunicação oral: é preciso suportar o deslocamento de sua zona de conforto para ir em direção à interação com o outro. Esperávamos que os participantes classificados nessa faixa manifestassem "tendências mais desejáveis" ao longo da entrevista, o que de fato se confirmou. Aqui estão as menores concentrações de conflitos. Dos oito participantes que deram essa resposta, apenas dois (F3 e M7 - um de nossos estudos de caso) têm altos índices de conflitos (relacionados à experiência, outras línguas e habilidade oral). Os outros 6 participantes (F6, F7, F10, M3, 
M4, M6) não apresentam tais conflitos, apenas deixam de usar materiais complementares ou mais propícios à reflexão linguística e por isso receberam a cor vermelha na seção "escola / estudo".

- A princípio, imaginava-se que as metas fossem refletir as motivações iniciais, porém, para as mulheres, a pesquisa mostra motivações iniciais essencialmente voltadas ao trabalho, enquanto metas e projeções futuras são mais pessoais ou intrínsecas. Essas tendências serão exploradas mais à frente.

Por fim, gostaríamos de reafirmar que em hipótese alguma estamos dizendo que apenas os sujeitos decididos a estudar por "interesse pessoal" vão aprender enquanto os outros fracassarão. Não é tão simples assim. Não concebemos a afetividade como filtro, mas como reguladora da ação humana. A teoria piagetiana da equilibração, como vimos, lembra-nos que a inteligência, ou a construção do conhecimento, é adaptação ao meio, e a necessidade de se adaptar no mundo move o sujeito a obter o conhecimento. Há, portanto, aspectos cognitivos e afetivos envolvidos nesse movimento. Além da motivação e da atribuição de importância existe também uma necessidade desequilibradora, impelindo o sujeito a procurar seu reequilíbrio e, consequentemente, produzindo conhecimento.

\subsubsection{Categoria Sentimentos}

Composta a partir das questões 3 (Como tem sido sua experiência com o inglês?) e 7 (Como você se sente falando inglês?). Será complementada pela questão 5 (Já estudou ou estudaria outra língua?). A Tabela de Frequência e as porcentagens estão baseadas num total de quarenta respostas (vinte da questão 3 e vinte da questão 7). Lembrando que o algarismo entre parênteses representa o número de ocorrências daquele tipo de resposta. 
(tabela 2)

\begin{tabular}{|c|c|c|c|}
\hline CATEGORIA SENTIMENTOS & $\begin{array}{c}\text { MASC } \\
\text { (20) }\end{array}$ & $\begin{array}{l}\text { FEM } \\
(20)\end{array}$ & $\begin{array}{c}\text { TOTAL } \\
\text { (40) }\end{array}$ \\
\hline 1. SENTIMENTOS NEGATIVOS & $\begin{array}{c}12,5 \% \\
(5)\end{array}$ & $\begin{array}{c}12,5 \% \\
(5)\end{array}$ & $\begin{array}{l}25 \% \\
(10)\end{array}$ \\
\hline 2. SENTIMENTOS AMBIVALENTES & $\begin{array}{l}30 \% \\
(12)\end{array}$ & $\begin{array}{c}22,5 \% \\
(9)\end{array}$ & $\begin{array}{c}52,5 \% \\
(21)\end{array}$ \\
\hline 3. SENTIMENTOS POSITIVOS & $\begin{array}{c}7,5 \% \\
(3)\end{array}$ & $\begin{array}{l}15 \% \\
(6)\end{array}$ & $\begin{array}{c}22,5 \% \\
(9)\end{array}$ \\
\hline
\end{tabular}

Em 1953 e 1954, Piaget proferiu, na Sorbonne, um curso intitulado "Les relations entre affectivité et l'intelligence", no qual faz articulações com a psicanálise e com as teorias de Claparède, Janet e Lewin. A tese defendida por Piaget durante seu curso é a de que não se pode entender as relações entre afetividade e inteligência de maneira dicotômica.

Há uma correspondência entre afetividade e inteligência durante o desenvolvimento psicológico, fazendo com que toda conduta seja, ao mesmo tempo, afetiva e cognitiva. No entanto, afeto e cognição têm naturezas distintas. Logo, a afetividade pode ser causa de condutas, pode intervir no funcionamento da inteligência, provocando acelerações ou atrasos no desenvolvimento intelectual, mas não produz novas estruturas cognitivas nem modifica o funcionamento das mesmas. Para exemplificar tais correspondências, Piaget nos diz que:

- $\quad \mathrm{Na}$ emoção (da ordem do afetivo), encontramos sempre discriminações perceptivas (da ordem do cognitivo);

- Na percepção, a afetividade intervém, por exemplo na eleição, na escolha. Dois sujeitos diferentes vão notar elementos distintos durante a observação de um quadro, por exemplo;

- A escolha tem relação com os diversos interesses, porém as leis da percepção são as mesmas para todos os sujeitos, variando apenas pelo estágio cognitivo em que estão. Desse modo, um adulto será capaz de observar os elementos de um quadro de uma maneira cognitivamente diversa de como uma criança o faz. 
Para Piaget, afetividade e sentimentos não são sinônimos. A afetividade compreende os sentimentos, as emoções e as tendências (como a vontade). Esta última diz respeito às preferências, às escolhas. Por isso optamos pelo uso do termo "tendências" no presente trabalho, fazendo alusão à afetividade envolvida no processo de aprendizagem da língua estrangeira.

É importante, ainda, lembrar que, diferentemente do que Piaget nomeia estrutura, a emoção pode ser tomada em termos de "mais" ou "menos", de "forte" ou "fraca" por se tratar de energética. Quando se fala em estrutura, há intelectualização, não se podendo qualificá-la como "forte" ou "fraca". As estruturas são, portanto, mais estáveis e fechadas, no sentido de se encaminharem para um equilíbrio terminal. A energética, ao contrário, é aberta. Haverá, portanto, uma penetração mais ou menos profunda da afetividade nas estruturas cognitivas. Além disso, a cada nível de estrutura cognitiva deve corresponder um certo nível de regulação energética.

Isso significa que um adulto, já tendo atingido o estágio das operações formais, tem a seu dispor "sentimentos ideológicos", uma combinação dos sentimentos interindividuais (caracterizado pelo intercâmbio afetivo entre os sujeitos, derivado da inteligência verbal e da socialização) e daqueles sentimentos que tem por objetivo os ideais coletivos.

Analisando os dados recolhidos nas entrevistas de acordo com as ideias aqui apresentadas, podemos extrair as seguintes reflexões:

- Um quarto dos participantes declarou algum tipo de sentimento de desconforto, experimentado em sua experiência de estudar a língua estrangeira ou no momento da comunicação oral, quando está mais vulnerável ao interlocutor e seus julgamentos. São eles: cansaço, dificuldade, travamento, vergonha, insegurança, medo de errar, constrangimento, desconforto, timidez. Em geral, os sentimentos negativos são desfavoráveis porque tendem a enfraquecer o contato do sujeito com a língua. Na tentativa de evitar o fracasso, o sujeito tende a se isolar, desenvolvendo bloqueios. Nesses casos, os sentimentos não propiciam a construção de valores centrais quanto ao idioma.

- Porém, pelo fato de concebermos a afetividade como energética e acreditarmos que ela não modifica as estruturas, podemos afirmar que sentimentos não produzirão déficits cognitivos. Consequentemente, mesmo com conotação negativa, não impedem o aprendizado; o que acontece é que poderá ocorrer de 
forma mais lenta. Percebemos isso várias vezes, por exemplo com alunos que declaram vergonha de se expressar oralmente. Muitos deles demonstram boa performance cognitiva - respondem corretamente às perguntas, desenvolvem um bom conhecimento da estrutura gramatical - porém evitam colocar esses conhecimentos em prática no momento da interação. Esse cenário pode ter ligação com a hierarquia de valores construída pelo aluno, conforme se verá na próxima categoria (valorizações)

- Assim, entendemos que a tonalidade afetiva é que realmente faz a diferença. De novo, se concebemos afetividade como energética, nenhum sentimento é em si negativo ou positivo. Depende da tonalidade e da conduta em que se apresenta. A maioria dos sentimentos, mesmo aqueles com conotação negativa, pode ser trabalhada para proveito do aluno. Com suporte, por exemplo de professores bem preparados, o aluno pode identificá-los e procurar dosá-los. A vergonha em excesso, ou o medo de errar, podem realmente impedir que o aluno se expresse, fazendo com que evite se expor. Mas a total falta de vergonha ou o excesso de confiança também farão o aluno cometer erros por não se comprometer com a precisão de sua interação e mesmo as correções do professor perderão a eficácia. Isso acontece com frequência naqueles casos nos quais o aluno declara que sua intenção é aprender a falar o idioma, não aprender gramática. Ele custa a perceber (às vezes não percebe) que a gramática serve para ordenar as estruturas linguísticas e consequentemente, as ideias. Para esses casos um pouco de sentimento de vergonha ou de medo de ajudariam a regular a conduta em prol da aquisição do conhecimento. Mesmo a ansiedade, que não apareceu em nossa pesquisa como sentimento, pelo menos, "consciente", mas que já foi discutida aqui e apontada em alguns estudos como a grande vilã da aprendizagem, pode, quando dosada, ter um papel regulatório benéfico, pois tem a função de sinalizar uma situação nova, um novo desafio para o sujeito, impelindo-o a superá-lo com agilidade.

- O adulto, como já dissemos, possui a vantagem de pertencer ao estágio formal, em que o possível é maior que o real. Tem um pensamento potente, com a capacidade de fazer conjecturas e traçar metas para o futuro. No plano afetivo, 
construiu os sentimentos ideológicos (sentimentos interindividuais + objetivos coletivos), com os quais pode se descentrar e se afirmar como parte integrante de um grupo, ou da sociedade, permitindo extrair benefícios da convivência coletiva. Numa sala de aula, onde o objetivo de se aprender algo é comum e cada experiência pode ser útil a todos, imaginamos que devesse haver a prevalência desse tipo de sentimento. Mas, foi possível observar, em nossos depoimentos, várias ocorrências de sentimentos como vergonha e timidez, sentimentos interindividuais - produtos do intercâmbio afetivo entre as pessoas - cuja tonalidade afetiva demonstra uma visão mais centrada no próprio sujeito do que em sua experiência dentro desse grupo de aprendizes. Por exemplo, a participante F4 se diz constrangida porque os professores corrigem e completam suas frases. Assim, não percebe a ação do professor como benéfica por se sentir constrangida dentro do grupo, ou seja, não há aí um sentimento ideológico que a mova a pensar nos benefícios dessa experiência como um todo. Considerando, claro, que o professor esteja sendo profissional e lhe dando suporte, completando-lhe as frases e corrigindo-a, todos os alunos da classe, além dela mesma, iriam usufruir dessa experiência e a participante seria beneficiada da situação de correção em geral, inclusive quando outras pessoas fossem corrigidas.

- 52,5\% dos participantes declarou sentimentos ambivalentes: gosto, mas sinto muita dificuldade / tem sido bem puxado, mas tem que se esforçar / um pouco traumática, mas gostava / gosto bastante, mas tenho alguma dificuldade / tem sido muito boa, tenho muita dificuldade / não tenho tanta dificuldade / complicado, mas avancei / não achei muito difícil, tenho dificuldade / legal, mas tenho um pouco de dificuldade / à vontade na escola, mas pressionado ou nervoso no trabalho/ às vezes sinto dificuldade, mas nos pubs converso numa boa / com meu irmão não tenho vergonha, mas com os professores fico constrangida / um pouco nervosa, mas acho que estou fazendo do jeito certo / sensação ruim, mas gratificante quando consigo falar / um pouco de medo no trabalho, mas com um nativo eu não teria medo / bem seguro, mas tenho vergonha de falar errado / parecendo um caipira porque a pronúncia não está correta, mas quando me corrigem me sinto tranquilo / um pouco difícil, mas quando monto uma frase me sinto feliz / nunca fui de ter vergonha de tentar, às 
vezes dá uma travada / ainda tenho que melhorar, mas acho que aprendi legal / realizado, ainda luto contra pensar em português.

- Julgamos ambivalentes, na verdade, uma combinação de sentimentos postos em oposição pelo próprio participante. A maioria afirma gostar do idioma, mas sente dificuldades de vários tipos, principalmente em relação à competência oral (expressar-se, formar frases). As situações produtoras de dificuldades são em grande parte ligadas ao trabalho, onde os participantes se sentem pressionados a mostrar bom domínio da língua.

- Um dado verificado aqui duas vezes (F9, M6 - questão 3), mas bastante comum nos discursos dos alunos é crer na existência de uma "dificuldade intrínseca", pessoal, ou seja, que a origem da dificuldade esteja nele mesmo, não no objeto de conhecimento, nem na relação entre ambos ("sou devagar”, "já esperava ter dificuldade"). Essa crença costuma gerar sentimentos bastantes negativos como fracasso - justamente por seu caráter intrínseco. Não foi o caso de M6 porque veio acompanhada por sentimentos mais favoráveis (“consegui evoluir”), mas F9 relata já ter estudado japonês "sem sucesso". Tal crença também costuma vir associada a sentimentos interindividuais - como vergonha e timidez - e dificilmente aparecerá relacionada a sentimentos ideológicos já que, atribuindo a dificuldade a si mesmo, o aluno deixa de olhar o coletivo por acreditar que o "problema” está nele próprio.

- Sustentamos que essas combinações de sentimentos também sejam mais periféricos na hierarquia de valores, pois a ambivalência torna a situação menos estável.

- $22,5 \%$ dos entrevistados declararam sentimentos positivos: muito bom / bastante agradável / bom / tenho aprendido realmente / ótimo / quanto mais estudo, mais me apaixono / boa e produtiva / sinto-me uma pessoa muito melhor / sinto-me passando na frente dos outros candidatos.

- Em nossa visão, os sentimentos positivos disponibilizam maior energética para a persistência no estudo e maior resistência a dificuldades e angústias no contato 
com a língua. São, portanto, os sentimentos mais propícios à construção de valores centrais quanto à língua, ainda que aqui não tenham sido identificados sentimentos propriamente ideológicos.

- No cômputo geral (resultado de "experiência" + "habilidade oral", questões que compõem a tabela 2), mulheres manifestaram mais sentimentos positivos que homens, conforme se vê na tabela 2.

- No quesito "habilidade oral", mulheres mostraram mais sentimentos negativos que homens (F2, F3, F5, F9 contra M2, M7). Acreditamos que esse cenário se explique pelo fato de as mulheres se exporem mais, conforme se verá na análise da Categoria Valorizações.

- Apesar de apresentarem mais sentimentos negativos quanto à "habilidade oral", só mulheres manifestaram sentimentos positivos quanto a isso (F6, F8).

- No quesito "experiências", homens declaram mais sentimentos negativos qua mulheres (M2, M5, M7 contra F9). Imaginávamos que pudesse haver relação quanto à (não) inclinação para estudar outras línguas (questão 5), porém isso só se confirmou em M5, que demonstrou experiências negativas e também baixa inclinação para o estudo de línguas: "não estudei", "não gostava", "não tenho tempo a perder”. M2 relatou experiências negativas, porém alta inclinação para línguas: "gostei”, "estudaria no futuro". M7 declarou experiências negativas e média inclinação para línguas: "tentei aprender", "gostaria de aprender por causa delas" (referindo-se à mãe à tia).

- Dos vinte entrevistados, cinco (F2, F6, F10, M2, M3) referiram inclinação ("alto interesse") para o estudo de línguas em geral (conferir questão 5). Imaginávamos que haveria uma relação entre tais inclinações e sentimentos positivos, pois o fato de o aprendiz já ter se interessado pelo estudo de outra língua indica valorizações centrais quanto a isso. Porém, quatro desses participantes (F2, F6, F10, M3), manifestaram também sentimentos ambivalentes (pouco estáveis) e um manifestou sentimentos negativos (M2). Ainda assim, mais uma vez, consideramos muito importante a tonalidade afetiva envolvida no esforço de 
aprendizagem. Como as tendências ao estudo de idiomas são boas preditoras de disponibilidade energética para a ação (valorização), os sentimentos ambivalentes podem ser julgados mais estáveis nesses casos.

\subsubsection{Categoria Valorizações}

Composta a partir da questão 8 (Você prefere falar, ler, escrever ou ouvir coisas em inglês? Coloque em ordem). Será complementada pela questão 4 (Por quê escolheu estudar nesta escola, com este método de ensino? Como você normalmente estuda? Como é sua rotina de estudos? Que horas estuda? Que materiais usa?). A Tabela de Frequência e as porcentagens estão baseadas num total de vinte respostas. Lembrando que o algarismo entre parênteses representa o número de ocorrências daquele tipo de resposta.

(tabela 3)

CATEGORIA VALORIZAÇÕES

1. PREFERE LER

2. PREFERE OUVIR
MASC

(10)

$20 \%$

(4)

$15 \%$

(3)
FEM TOTAL

(10)

(20)

$15 \% \quad 35 \%$

(3)

(7)

$10 \%$

(2)

3. PREFERE ESCREVER

$5 \%$

$5 \%$

(1)

(1)

$10 \%$

$25 \%$

$35 \%$

4. PREFERE FALAR

(2)

(5)

(7)

Em sua teoria, Piaget foi além do papel regulatório dos sentimentos, agregando a essa base um segundo sistema regulatório: o sistema de interesses, ou seja, de valor da ação.

Para começar, faz uma distinção entre valor e custo da ação. Uma ação custosa pode ser preferida a uma ação menos custosa, se esta última for pouco valorizada. Em outras 
palavras, um sujeito prefere empregar mais esforço (ou dispor de mais energética) para realizar algo que seja mais valorizado para ele.

Logo, a valorização não é uma questão de economia da ação. Piaget exemplifica com o episódio de um bebê que tenta puxar um brinquedo para dentro de seu chiqueirinho, através das grades. Ao obter êxito, ao invés de se contentar com o brinquedo, ele o joga novamente para fora e recomeça suas tentativas, no intuito de entender a técnica.

Aqui, já existe um sistema de interesses coordenados. O bebê está interessado, a priori, no brinquedo. Mas, depois, volta sua atenção para a técnica de obtenção do brinquedo, descoberta casualmente. Esse novo interesse, apesar de mais custoso, está agora hierarquicamente superior ao primeiro, ou mais valorizado.

Assim, o valor está ligado “à expansão do eu na conquista do universo" e constitui “o aspecto qualitativo do interesse", determinando as energias que serão empregadas na ação. É o "enriquecimento" da ação, ou seja, um objeto (ou pessoa) tem valor quando o sujeito é capaz de enriquecer a ação direcionada a esse objeto (ou pessoa). Pode ser em termos de força ou, principalmente, em termos funcionais: o objeto (ou pessoa) valorizado pode ser fonte de novas atividades. Por isso acreditamos que as tendências para o estudo de línguas em geral sejam boas preditores de sucesso na aquisição de um idioma: se há valorização do conhecimento linguístico, esse valor poderá impulsionar o aprendizado de uma ou várias línguas.

Dessa maneira, os interesses de uma pessoa - agora pensando nos adultos que são nosso público nas escolas de idiomas - estão organizados num sistema hierárquico de valores.

Aprender uma língua estrangeira, fazer pós-graduação, viajar, fazer intercâmbio, casar-se são alguns dos interesses na faixa de idade de nosso público. E todos vão ser ordenados de acordo com o valor atribuído a cada um, de acordo com o papel que cada um ocupa na expansão do sujeito na conquista de alguma coisa (um cargo melhor, uma experiência nova, realização financeira, etc.).

Importante salientar que, em nossa visão, não se trata simplesmente de estabelecer prioridades. Um sujeito pode ter vários desequilíbrios que demandem adaptação, forçando-o a agir afetiva e cognitivamente para se reequilibrar de acordo com os mais urgentes, não necessariamente as mais valorizadas para ele.

Além do mais, o valor faz parte de uma dimensão geral da afetividade, portanto Piaget não o considera um sentimento.

Partindo das ideias de piagetianas, propomos uma discussão sobre as quatro habilidades envolvidas no aprendizado de uma língua e, posteriormente, uma análise do uso 
de materiais de apoio, buscando identificar as valorizações de nossos aprendizes participantes e refletir sobre elas.

Para efeito didático, consideraremos tais habilidades como atividades de recepção ou atividades de produção. Ouvir e ler constituiriam atividades de recepção na medida em que, apesar de demandarem elaborações mentais, implicam, num primeiro momento, recebimento e construção de sentido da mensagem, sem necessariamente interação com o outro físico. Falar e escrever seriam atividades de produção, pois tanto demandam elaborações quanto pressupõem interação com o outro.

Sabemos que tais classificações são bastante esquemáticas. No entanto, como nosso foco está na interação entre sujeitos, o esquema acima será capaz de suprir nossa necessidade. Quanto à ler, estamos cientes de que significa muito mais que simples decodificação de materiais escritos, mas, para nosso trabalho, seu significado estará ligado à compreensão desses conteúdos.

Para entender as valorizações, precisamos também entender quais são as dificuldades predominantes em cada habilidade.

A leitura, por exemplo, oferece diversos obstáculos. Em língua estrangeira, quando não acontece decodificação, a primeira barreira costuma ser a do reconhecimento da função daquela palavra naquele contexto (verbo, substantivo, adjetivo, etc) para então saber como procurar seu significado num dicionário. Muitos de nossos alunos tropeçam aí, ou porque se prendem a frases isoladas ou a cada palavra - decifrando-as uma a uma, procurando significados sem fazer conexões com o todo do texto nem ir além dele, fazendo pouco ou nenhum uso de inferências - e a atividade de leitura torna-se uma tortura lenta e interminável, ou, ao contrário, fazem uma leitura superficial do material, fortemente apoiada em seus conhecimentos prévios, efetuando diversas adivinhações e selecionando as informações mais relevantes para eles próprios (leitores bottom-up e leitores top-down - Kato, 1985 APUD Santos e Kader, 2012).

Ainda assim, dentre as atividades de recepção (ler e ouvir) os participantes têm uma ligeira preferência pela leitura (35\% contra 25\%). Apenas $10 \%$ (F7, M10) classificaram ler como a habilidade menos apreciada. Algumas das justificativas apontadas para a preferência foram as seguintes:

- a leitura já vem "pronta" (F4)

- o leitor pode imprimir seu ritmo (F1, M7, M8)

- $\quad$ é possível adquirir vocabulário (F2) 
De acordo com a possibilidade de interação, consideraremos ler como a atividade mais receptiva de todas - seguida por ouvir, escrever e finalmente falar, que seria, nesse esquema didático, a mais produtiva. Mesmo com todas as dificuldades elencadas acima, a leitura é apreciada por grande parte dos aprendizes, muito provavelmente por ser a que menos os desloca de sua zona de conforto.

Por outro lado, quando a leitura é apreciada por ser custosa para o aprendiz (em termos piagetianos), é porque existe valor e consequentemente, enriquecimento da ação, possibilitando impulsionar novas ações. Claro, ser uma ação custosa não quer dizer ser “exaustiva”. Quer dizer que o aprendiz emprega energia para extrair significado de sua ação, por exemplo, quando se serve do texto para "ganhar" algo (vocabulário, expressões, estruturas novas) que posteriormente pode ser aplicado em outras ações - na fala, por exemplo. Ser custosa, portanto, implica em aproveitar o potencial reflexivo de cada atividade. Ai, sim, pode-se dizer que a leitura produziu valorizações quanto à aprendizagem do idioma.

Em se tratando de audição, a dificuldade reside também na decodificação, desta vez, fonética. Dificuldades de reconhecimento e de segmentação dos sons pela velocidade da fala, pela pronúncia (sotaque) e pelo desconhecimento do vocabulário. Às vezes leva algum tempo para o ouvinte adaptar-se a todos esses elementos, resultando em perda de informações.

$25 \%$ (F5, F9, M2, M5, M6) dos entrevistados prefere ouvir enquanto $15 \%$ deles (F4, F8, M7) classificaram-na como a habilidade menos apreciada. Um dos participantes (F5) mencionou gostar do som da língua, isto é, da prosódia, talvez por influência cultural, pela disponibilidade de músicas em inglês na atualidade.

Acreditamos que ouvir, apesar de ser uma atividade predominantemente receptiva (de acordo com os parâmetros aqui estabelecidos), deve deslocá-los mais de sua zona de conforto, na medida em que o ouvinte depende do falante. Na atividade de ouvir, o sujeito fica mais vulnerável do que na atividade de ler: ele não dita o ritmo nem tem a possibilidade de consultar os significados das palavras. Precisa reconhecer e adaptar-se rapidamente aos sons para entender as informações. Desta forma, e sobretudo quando tal ação é custosa, deve ajudar a construir valorizações mais centrais do que a ação de ler.

Quanto à atividade de escrever, 10\%, ou seja, apenas um participante (M10) a citou como favorita, enquanto sua rejeição foi de 30\% (F3, F9, M2, M4, M6, M9).

Além dos aspectos formais envolvidos na escrita (domínio da gramática / estrutura / vocabulário, coerência, coesão, etc.) há ainda o problema da ortografia, tornando o ato de escrever algo bastante complexo.

É uma atividade de produção que, apesar de não necessariamente propiciar interação 
face a face entre os sujeitos, pressupõe interlocutores. Logo, há interação. Possibilita considerável deslocamento do aprendiz de sua zona de conforto, mas também permite o gerenciamento do tempo pelo escritor, para reflexão e adequação de suas ideias ao contexto. Mesmo assim, muitos alunos, diante de atividades de escrita, escrevem pouco porque julgam não saber fazê-lo e declaram ter vergonha de escrever incorretamente (o sentimento de vergonha aparece novamente). A julgar pelos resultados, é uma ação mais exaustiva do que custosa, podendo não resultar em boas construções de valores.

$35 \%$ dos entrevistados prefere falar (F3, F6, F7, F8, F10, M4, M9), perfazendo $25 \%$ de mulheres e 10\% de homens. Aqui, há uma diferença notável entre os gêneros. Os resultados nos levam a crer que as mulheres expõem-se mais, ou seja, estão mais propensas à interação. Talvez explique o fato de demonstrarem mais sentimento negativos relacionados à habilidade de falar.

30\% (F2, F5, M1, M3, M5, M8) classificaram-na como a habilidade menos apreciada. De novo, os homens é que relatam mais dificuldades nessa atividade.

Falar é a atividade de produção que mais desloca os aprendizes. Em nossa visão, é a que proporciona construção de valores mais centrais. Os sujeitos envolvidos na interação deparam-se com uma imensidão de variáveis pouco controláveis (fonética, ritmo, entonação, vocabulário, etc.), sem contar o tempo relativamente limitado de resposta. Dessa maneira, aguentar a interação com o outro requer uma energética potente, ou seja, um valor. Além disso, a interação não está centrada nem em um sujeito nem no outro, mas no processo. Se o objetivo é comunicar, provavelmente a ação de falar, no aprendizado de uma segunda língua, ajude, inclusive, a desenvolver sentimentos ideológicos em benefício da interação do par ou do grupo.

Falar e escrever - atividades de produção - ocupam um lugar privilegiado nas escolas de idiomas. Sem dúvida são importantíssimas, especialmente por propiciarem os maiores deslocamentos dos alunos de suas zonas de conforto (o que deve explicar o índice de $60 \%$ de rejeição) e consequente construção de valores. No entanto, reiteramos que, em nossa visão, parte do esforço pode ser desperdiçado quando essas atividades forem mais exaustivas que custosas para o aprendiz. Achar, portanto, a fronteira entre esses elementos é o desafio de todo professor e de toda escola de idiomas.

Em relação ao uso de materiais (questão 4), veremos quais atitudes são mais favoráveis (ou menos favoráveis) à construção de valores. Devemos lembrar que os alunos escolhidos para fazer parte da pesquisa são todos de nível intermediário, teoricamente já com certa autonomia em relação ao professor e tendo desenvolvido algumas estratégias de 
aprendizagem pessoais.

Diante do exposto e a partir dos depoimentos, extraímos as seguintes reflexões:

- $\quad 30 \%$ dos alunos entrevistados declara não utilizar nenhum material além daquele fornecido pela escola: livro didático - idealizado e produzido pela própria escola - contendo os diálogos dos personagens da história-cenário, a explicação do ponto gramatical (em inglês), os exercícios de gramática e algumas propostas de produção de texto; CD com as gravações dos diálogos.

- Lembramos que os estudantes têm duas aulas presenciais durante a semana: uma de gramática e outra de conversação. Para aula de gramática, existe uma "preparação" que consiste em ler e ouvir os diálogos, estudar o ponto gramatical e fazer os exercícios de gramática antes de comparecer à aula. Essas tarefas devem ser realizadas diariamente, com algumas variações: ler o diálogo, ouvindo a gravação de sua aula semanal por dois dias seguidos; ler, ouvir e repetir a gravação (mais dois dias seguidos); estudar a gramática e fazer os exercícios (um ou dois dias).

- Ocorre que, muitas vezes, a explicação gramatical do livro não é suficiente para dirimir as dúvidas do aluno, o que é bastante normal, pois até então não houve mediação do professor. Sendo assim, para alunos no nível intermediário que estudam pontos gramaticais já bastante complexos, tempos verbais compostos como os tempos perfect - calculamos que $30 \%$ seja uma porcentagem muito alta de não utilização de materiais de apoio. Tal fato nos leva a duas possibilidades: primeiro, mesmo sendo intermediário aluno ainda não é autônomo o suficiente, talvez por falha do método que não os orienta adequadamente ou por comodismo do próprio estudante; segundo, não há energética suficiente impulsionando a busca autônoma pelo conhecimento. Dito de outra forma, não há valorização dessa ação. Essa é uma das atitudes, para nós, desfavoráveis ao sucesso na aquisição do idioma, inclusive por propiciar pouco deslocamento da zona de conforto.

- $\quad 55 \%$ dos participantes declara usar - como material de apoio - músicas, seriados e filmes. Essa alta porcentagem denota, por um lado, a preocupação de mais da 
metade dos alunos em encontrar uma maneira de complementar seus estudos. Denota, portanto, certa valorização. Mas será que esses recursos realmente prestam auxílio como produtores de conhecimento? Ou são apenas atividades prazerosas para o aluno e, no fundo, servem apenas como fonte entretenimento?

- Sustentamos que pode existir, sim, benefício no uso de recursos de entretenimento para o aprendizado, desde que haja certa apropriação do conhecimento, ou seja, quando o aprendiz é capaz de identificar elementos (estruturais, semânticos, etc.) e usá-los em outros contextos. Porém, para que isso ocorra é preciso haver intencionalidade e, consequentemente, reflexão. Em termos piagetianos, como já vimos, envolve valor e custo da ação. Ouvir uma música ou assistir a um filme sem dispender energética para se concentrar nesses elementos e refletir sobre eles é entretenimento. Nesses casos, pode vir a acontecer de um ou outro elemento ser notado casualmente, fazendo com que muitos alunos confundam tais casualidades com a ação de estudar.

- $15 \%$ dos entrevistados usa gramática impressa, acessa sites de gramática ou de exercícios. Esses são os tipos de materiais mais desejáveis como complementos de estudos, gerando maiores chances de produzir reflexão, uma vez que o aluno precisa selecionar e elaborar as informações aí encontradas. São ações mais custosas, ou seja, dispendem energética para a ação, portanto impulsionando a construção de valores centrais quanto ao idioma.

- Quanto ao uso de dicionários, pareceu-nos ser uma prática quase em desuso na atualidade, devido à facilidade de acesso aos sites de tradução. Na tela do computador ou do celular, a grande maioria dos estudantes dispõem desses aplicativos (65\% dos participantes). Vale o mesmo raciocínio anterior: o benefício vem da possibilidade de reflexão e do custo da ação.

\subsubsection{Categoria Metas}

Composta a partir das questões 10 (A experiência de estudar inglês mudou alguma coisa na sua vida ou em você?) e 11 (Como você se vê no futuro com o conhecimento em inglês?). A Tabela de Frequência e as porcentagens agora estão baseadas num total de 
quarenta respostas (vinte de cada questão). Lembrando que o algarismo entre parênteses representa o número de ocorrências daquele tipo de resposta.

(tabela 4)

\begin{tabular}{lccc}
\hline CATEGORIA METAS & MASC & FEM & TOTAL \\
\hline & $(\mathbf{2 0})$ & $\mathbf{( 2 0 )}$ & $\mathbf{( 4 0 )}$ \\
1. EVENTUAL / CASUAL & $15 \%$ & $10 \%$ & $25 \%$ \\
& $(6)$ & $(4)$ & $(10)$ \\
\hline 2. PROFISSIONAL & $27,5 \%$ & $7,5 \%$ & $35 \%$ \\
& $(11)$ & $(3)$ & $(14)$ \\
\hline 3. PESSOAL & & & $40 \%$ \\
\hline
\end{tabular}

Aprendemos com Piaget que o interesse é o impulso afetivo para um melhor funcionamento da inteligência. Cada interesse é revestido de uma energética, atribuindo-lhe, assim, um valor que, por sua vez, é organizado num sistema de valores, orientados do centro (os valores mais fortes) para a periferia (os mais fracos).

Cada novo interesse assume uma posição nessa hierarquia em função de sua energética (valor) e essas posições podem variar de acordo com os novos interesses que vão surgindo face aos desafios do sujeito em contato com o mundo.

A busca por adaptação ao mundo, envolve, por sua vez, fatores afetivos e cognitivos, isto é, o sujeito precisa pensar COMO executar alguma coisa (essencialmente cognição) e O QUÊ executar (essencialmente afetividade). Logo, o sujeito precisa fazer escolhas.

As escolhas são essencialmente afetivas, posto que são produzidas a partir dos interesses e, ao se escolher algo, estabelecem-se metas. As metas estão ligadas portanto, a uma necessidade desequilibradora que impele o sujeito a buscar uma solução com os meios cognitivos e afetivos dos quais dispõe. Os adultos, no caso, têm a vantagem de dispor das operações formais, sendo capazes de trabalhar com hipóteses e projeções no futuro.

Acreditamos que as metas relacionam-se não só às motivações que deram impulso ao estudo, mas igualmente às valorizações construídas na experiência de aprender uma língua. 
Das respostas às questões obtidas dentro da Categoria Metas, pode-se extrair as seguintes reflexões:

- $25 \%$ dos participantes demonstraram metas pouco definidas no que diz respeito ao uso do conhecimento linguístico no futuro. O dado em si não parece muito promissor, visto que, como dissemos, é vantagem do adulto planejar suas ações futuras, testando mentalmente suas hipóteses. A princípio, pode ser indício de que os valores a respeito do idioma, construídos ao longo do processo de aprendizagem, não estão em posições centrais.

- Achávamos que haveria forte relação entre "metas casuais" e motivações impulsionadas por "crença na universalidade da língua", o que se confirmou em $50 \%$ do casos (menos do que o esperado). Dos oito participantes que deram pelo menos uma resposta "crença na universalidade" (F2, F6, F8, F9, M2,M3,M9, M10), quatro apresentaram "metas eventuais/casuais" (F6, M2, M3, M10). Esse cenário também não se mostra ideal para a construção de valores, pois parte de uma motivação pouco objetiva e culmina numa meta igualmente difusa. Porém em F6 e M 10, são observadas tendências intrínsecas quanto a sentimentos e valorizações, então deve haver aí energética o suficiente para construção de valores centrais quanto à língua.

- $35 \%$ dos participantes declararam metas profissionais. Esse resultado nos surpreendeu pois, levando em conta que as motivações profissionais (iniciais) perfizeram 52,5\%, esperávamos maior porcentagem de respostas declarando metas profissionais.

- Contudo, não tomamos esse dado como desfavorável, ao contrário, explica-se aqui pelo fato de o aspecto "pessoal" ter superado o aspecto "profissional". É um indício muito favorável de que os adultos vão descobrindo outros conhecimentos ao longo do processo de aprendizagem, e estes novos interesses incorporam-se ao sistema de interesses do sujeito, ocupando posições privilegiadas. Nossa pesquisa mostrou que os novos interesses são mais intrínsecos que os anteriores, portanto mais favoráveis, nesse caso. 
- $40 \%$ dos entrevistados demonstrou metas pessoais. Como dissemos, esse dado é altamente auspicioso. É a implicação pedagógica mais relevante para nós, porque demonstra claramente os benefícios de um processo de aprendizagem: os sujeitos se modificam para se adaptar. E modificando-se, são capazes de intervir no ambiente. Isso é inteligência para Piaget. Ainda melhor quando conseguem perceber essas mudanças em si mesmos e projetá-las em seu futuro, como se vê nos depoimentos.

- O dado mais surpreendente tem relação com o sexo feminino. Perguntadas sobre o que mudou nelas mesmas ou em sua vida a partir da aquisição do conhecimento linguístico (questão 10), nove entre dez observaram mudanças pessoais. A princípio, elas apresentaram os maiores índices de motivações profissionais, porém, a exposição a um idioma novo - com sua cultura subjacente e com os deslocamentos implicados no processo de aprendizagem parece ter colaborado amplamente na construção de valores centrais, refletidos nas mudanças por elas experimentadas.

- Apenas dois participantes do sexo masculino afirmaram mudanças pessoais (M4, M6). Entre eles, as mudanças (questão 10) aconteceram majoritariamente ao ambiente profissional, conforme se observa no depoimento de cinco entrevistados (M1, M5, M7, M8, M9).

\subsubsection{Relações entre as línguas}

A escolha deste ou daquele idioma também está sujeita a hierarquia de valores, devido à natureza complexa de uma língua, que implica entrar numa cultura, pertencer ou identificar-se com um grupo, produzir interação, deslocar-se da zona de conforto, enfim. Prova disso são os adjetivos usados pelos participantes para descrevê-las: bonita, cantada, forte, feia, importante, interessante, difícil, maravilhosa, charmosa, desafiadora, complicada.

Por isso, mesmo presumindo que as inclinações para o estudo de línguas em geral sejam boas preditoras de sucesso no aprendizado, gostar de estudar um idioma não significa gostar de estudar todos, devido às escolhas afetivas do sujeito em relação aos idiomas em jogo; devido aos interesses do sujeito e a energética - ligada ao valor - de que dispõe para o estudo de cada um. 
A partir dessas ecolhas afetivas, os sujeitos tendem, também, a comparar as línguas entre si, relacionando-as em alguns aspectos, afastando-as em outros, fazendo julgamentos de superioridade / inferioridade entre elas.

Sustentamos que a discussão sobre as relações interlinguísticas é relevante no processo de ensino-aprendizagem de um idioma, não só porque evidencia a diversidade cultural entre os falantes dessas línguas, mas também por estimular a reflexão sobre os aspectos estruturais inerentes a cada língua, por exemplo quanto à (re)construção dos tempos verbais. Na medida em que o tempo é uma noção comum ao ser humano, o tempo das ações tempo verbal - resolve-se de maneiras diversas de acordo com cada idioma. Assim, na maioria das vezes, não é possível simplesmente transferir os princípios de uma língua para outra. E não estamos falando de tradução, mas de conceitualização e de aplicação, uma vez que não se pode ignorar a presença da língua materna e de sua lógica.

Vejamos, então, algumas reflexões sobre a questão 9 (Estudar inglês o fez se aproximar mais de sua língua nativa, o português? Como?):

- $\quad 20 \%$ dos entrevistados não fez qualquer relação entre as línguas (F2, F7, M1, M6). Esse dado sugere duas possibilidades: primeiro, como o método da escola não encoraja as traduções, é provável que alguns dos alunos evitem aproximá-las para não resultar em tradução; segundo (o mais provável), existe uma confusão natural entre aproximar e traduzir.

- $\quad 20 \%$ faz relação de superioridade ou de inferioridade (F1, F5, F10, M10). Em geral, o discurso aponta superioridade da língua portuguesa em relação à inglesa em termos de complexidade. A ideia, já mencionada por Ortiz (2008), da suposta simplicidade do inglês, mesmo não tendo sido o principal objetivo da pergunta, apareceu espontaneamente nos depoimentos, levando-nos a crer na possibilidade de outros alunos compartilharem dessa concepção. Aliás, em nossa experiência de mais de doze anos de docência, encontramos professores que também difundem essa crença.

- Em nossa opinião, a ideia de fácil ou difícil em um idioma é bastante subjetiva e liga-se a uma comparação quantitativa entre as línguas - em termos de fonética, tempos e conjugações verbais, etc. Por exemplo, muitos alunos (e alguns professores) associam o fato de haver mais flexões nominais e verbais em 
português a um maior nível de complexidade dessa língua. Em contrapartida, aqueles que acham inglês mais difícil atribuem isso ao fato de haver mais sons de vogal em inglês que em português. Em suma, a ideia da dificuldade parece relacionar-se à maior quantidade de alguma coisa em uma língua que na outra, e não aos mecanismos da própria língua. A nosso ver, a "dificuldade" reside na reorganização cultural que a nova língua propõe. A cada língua que se aprende, aprende-se também um novo raciocínio, um novo ponto de vista. E quem não está disposto - não tem energética o suficiente - vai realmente experimentar algum tipo de desconforto. Além disso, na maioria dos cursos de idiomas, não há realmente a intenção de se chegar à análise de estruturas muito complexas, devido ao propósito da maioria deles que consiste em formar sujeitos para se comunicar, em geral. Logo, grande parte dos alunos acaba com essa impressão de que tudo é mais simples, em inglês. Pena que acreditar na simplicidade do inglês não torne o aprendizado mais fácil para muitos de nossos alunos.

- $60 \%$ dos participantes faz relação de aproximação. Porém, a grande maioria deles aproximou as línguas pela existência de regras gramaticais ou pela observação de algum aspecto semântico (por exemplo, ao se adquirir vocabulário em uma língua, ambas se beneficiam por essa associação). Tal aproximação é a mais evidente, na medida em que o estudo da gramática (e suas regras) normalmente faz parte das aulas. Porém, o aspecto que mais nos interessava - a noção do funcionamento linguístico - apareceu apenas uma vez (em F3): "Acho que sim. Se a gente não souber como funciona na língua portuguesa, não tem como traduzir. No português já temos noção de passado, presente".

- Apesar desta aproximação vir ainda associada ao ato de traduzir, a participante fez menção ao funcionamento inerente às línguas e à noção de tempos verbais. Aparentemente, existe percepção de diferenças quanto às propriedades de cada língua, seu funcionamento, sua lógica, o que, para nós, está além das regras como em um jogo, conhecer as regras não significa entender sua lógica interna e as estratégias para vencer - e consiste, pois, numa resposta mais acurada, a nosso ver. 


\section{Estudos de Caso}

Foram selecionadas quatro das vinte entrevistas para discussão sob forma de estudos de caso, analisando-se a trajetória de cada um desses participantes individualmente, relacionando a qualidade de suas motivações aos seus sentimentos, valorações e projeções futuras. Os critérios de escolha foram a coerência entre as categorias acima apresentadas ou, ao contrário, inconsistências entre elas.

\subsection{Primeiro Estudo de Caso: F9}

Trata-se de uma jovem de 27 anos, que trabalha como designer gráfica. Através de seu depoimento, pudemos fazer as seguintes observações:

- Motivações: Quando perguntamos por que estudava inglês, a jovem disse que "é uma necessidade", "uma língua universal”. Perguntada sobre a importância desse estudo, repetiu a resposta da questão anterior: "é uma necessidade", "é importante porque é universal”. Na Categoria Motivações, portanto, observamos razões extrínsecas movendo o aprendizado. Conforme já explicitado, imaginamos que acreditar na universalidade de língua é uma motivação um tanto vaga. Nesse caso, a crença apareceu nas duas oportunidades de resposta, demonstrado, por um lado, coerência na fala da participante, mas ao mesmo tempo potencializando o caráter impreciso da motivação. Não fica claro se a participante pensa que precisará desse conhecimento um dia e por isso preparase para o futuro ou se investe na língua como um fundo de "commodities" (Jordão, 2004): no caso de um dia precisar, o conhecimento estaria ali. Dependerá em parte da objetividade de suas metas. Quanto à aplicação, faz uso essencialmente instrumental, em materiais de sua área de atuação (programas), e nos momentos de entretenimento (filmes, música). Esse tipo de aplicação, mesmo não fazendo parte das tendências mais desejáveis - por ser mais passivo e deslocar pouco o sujeito de sua zona de conforto - é importante para manter em uso um conhecimento que está sendo consolidado, especialmente no tocante às línguas, pois tal atitude mantém a energética em jogo e aumentam-se as chances de valorização. 
- Sentimentos: Verificaram-se sentimentos bastante negativos, relacionados a uma dificuldade "intrínseca" - atribuída a si mesma - nas duas oportunidades de respostas, isto é, tanto na experiência com o idioma quanto na percepção de sua competência oral: "Eu sempre tive muita dificuldade; sou muito devagar para aprender linguagem; não sei porque tenho dificuldade". Além disso, manifestou baixa inclinação para línguas, quando declarou não ter obtido êxito no estudo de japonês (língua que os pais falam), não ter dado continuidade ao espanhol e nem ter ambição e estudar qualquer outra língua. Vimos que sentimentos, apesar de não modificarem as estruturas cognitivas, provocando déficits, desempenham papel fundamental no processo de construção de valores. Ocorre que sentimentos com tonalidades negativas podem colaborar para a lentidão do aprendizado, levando a outros sentimentos ou tendências - como fracasso e desânimo - e enfraquecendo o contato do sujeito com o idioma. Desse modo, a energética empregada não é suficiente para a construção de valores centrais, que o ajudariam a suportar melhor o contato com o idioma e tudo aquilo que está envolvido nesse contato.

- Valorizações: Por um lado, mesmo não evidenciando propensão natural ao aprendizado da língua, percebe-se, no discurso da participante, certa curiosidade envolvida no desejo de aprender inglês, como acontece com muitas pessoas inseridas na área da informática. Ou seja, existe aí uma tendência afetiva com tonalidade positiva, já que a curiosidade passa pelos interesses. Por outro lado, a participante tem preferência por ouvir em inglês, isto é, uma habilidade predominantemente de recepção, demonstrando deslocar-se pouco de sua zona de conforto. $\mathrm{O}$ aspecto favorável no ato de ouvir encontra-se no fato de requer rápida adaptação ao outro, uma vez que, para compreender o interlocutor, faz-se necessário acompanhar seu ritmo para evitar prejuízo na decodificação. Se a ação de ouvir for, ainda, custosa para a participante, torna-se um caminho possível para a construção de valores centrais. Quanto ao uso de materiais, mostrou-se propensa a recorrer àqueles que propiciam maior reflexão, como gramáticas impressas, cujas informações precisam ser selecionadas e elaboradas para seu bom aproveitamento.

- Metas: No que diz respeito a mudanças, a entrevistada mostrou orientação 
notadamente intrínseca ("me sinto mais adulta; mais intelectual, mais inteligente"). Essa fala denota percepção do processo de aprendizagem como agente modificador, como construtor de inteligência, o que também é um passo na direção da valorização do estudo da língua. Quanto aos objetivos futuros, a jovem privilegiou o lado profissional, mais extrínseco ("pretendo trabalhar numa multinacional, ter sucesso na carreira"). Temos, então, metas combinadas, uma mais intrínseca e outra mais extrínseca, mas que revelam objetivos claros quanto ao uso do conhecimento linguístico.

- Relação entre as línguas: A participante faz relação de aproximação semântica: "Procurando uma palavra que não sabia em inglês, acabo aprendendo em português também". Isto é, acredita numa aproximação em termos mais quantitativos, com ampliação de vocabulário em português em consequência do contato com palavras desconhecidas em inglês. Tal aproximação é, como mencionamos antes, mais óbvia, superficial, porém significa que a aprendiz relaciona, de alguma forma, os conhecimentos linguísticos. A aproximação mais desejável seria em termos de funcionamento, de mecanismo linguístico.

- Considerações: Esse caso nos sugeriu valorizações ainda bastante periféricas em relação ao aprendizado, especialmente no que diz respeito às motivações iniciais e aos sentimentos experimentados na relação com o idioma. Porém, aparentemente, no decorrer do processo, a participante começou a encontrar sentido em suas ações, culminando no estabelecimento de metas claras e na percepção de mudanças favoráveis em si mesma. Acreditamos que a persistência por ela declarada (“dessa vez não vou desistir”) poderá garantir a continuidade do processo de aquisição do conhecimento e sua progressiva valorização.

\subsection{Segundo Estudo de Caso: F10}

Jovem de 24 anos, do sexo feminino, trabalha como relações públicas. De seu depoimento, pudemos extrair as seguintes reflexões:

- Motivações: Revelou motivações intrínsecas em ambas as oportunidades de 
resposta: deseja aprender para comunicar-se numa viagem e acredita ser importante para se expandir e adquirir cultura. Interessante notar que a aprendiz revelou mudança em suas motivações - antes eram relacionadas ao trabalho. Aparentemente, essas mudanças ocorreram após seu ingresso no curso, através do contato com o idioma ('peguei gosto pelo inglês"). Mencionou, ainda, a difundida crença na universalidade. Quanto à aplicação, assim como no depoimento anterior, a participante faz uso essencialmente instrumental, para leitura de alguns poucos textos em inglês em seu ambiente profissional. Não é o mais desejável, porém há percepção de potencial de aplicabilidade para o conhecimento.

- Sentimentos: Apesar de seu foco agora ser na conversação, manifesta sentimentos ambivalentes em relação à habilidade oral: "Ainda um pouco dificultoso; mas quando consigo montar uma frase inteira, me sinto muito feliz". $\mathrm{Na}$ verdade, não relatou sentimentos negativos, apenas ressaltou a questão da dificuldade, tanto em gramática (ao mencionar sua experiência), quanto na produção de frases coerentes (ao comentar sua competência oral). Contudo, revelou inclinações para línguas, desejando poder dar continuidade ao estudo de espanhol, interrompido por falta de tempo. Acreditamos que este depoimento, em geral, revela energética disponível para a construção de valores centrais.

- Valorizações: A entrevistada manifesta disposição para deslocamentos em sua zona de conforto. Como seu foco é comunicar-se com as pessoas numa situação de viagem, mostra-se decidida a expor-se numa interação. Já em relação ao uso de materiais de suporte, faz menção à utilização de filmes como complemento de estudo, bem como sites de tradução. De acordo com discussões anteriores, não consideramos tais materiais como ideais para produção de reflexão linguística, especialmente quanto aos sites que trazem as traduções prontas.

- Metas: Nesse caso, nota-se que as metas refletiram as motivações iniciais: são igualmente intrínsecas, referem-se à possibilidade de comunicação e de intercâmbio entre pessoas e culturas. As mudanças revelaram-se bastante pessoais, isto é, a participante percebe os benefícios do processo de aprendizagem em si mesma, a partir de novas adaptações ao mundo. Sua meta é 
altamente comunicativa e, para tanto, deverá dispor de bastante energética na interação.

- Relação entre as línguas: Está entre os entrevistados que acreditam na superioridade da língua portuguesa em relação à inglesa: "Português é mais complexo que inglês". Ou seja, faz-se necessário possibilitar aos nossos alunos reflexões sobre os mecanismos linguísticos, para acurar as relações entre as línguas.

- Considerações: Observamos aqui um caso de mudanças qualitativas - havia, a princípio, um interesse mais extrínseco pelo idioma, ligado ao profissional (“antes meu foco era profissional") e através do contato e do progresso nos estudos, outro interesse ("viajar e conversar") foi percebido e colocado em posição mais central. Apesar de haver ainda certa ambivalência na experiência e na habilidade oral, as tendências intrínsecas mostraram-se mais fortes durante todo o depoimento, indicando um processo de construção de valores centrais quanto ao idioma estudado.

\subsection{Terceiro Estudo de Caso: M7}

Este participante tem 38 anos e é técnico em radiologia. Abaixo, as observações sobre seu depoimento:

- Motivações: O entrevistado demonstrou, a princípio, motivação intrínseca: aprender inglês para comunicar-se durante uma viagem. Quando questionado sobre importância, mostrou-se coerente, repetindo parcialmente a resposta anterior: "Para mim, seria mais para uma viagem; ajudaria muito; na profissão, um pouco". Ainda que a viagem não tenha se concretizado, o participante resolveu continuar o curso. Porém, aparentemente, a motivação intrínseca não se manteve, visto que apresenta muitos conflitos quanto à sentimentos e valores, chegando mesmo a declarar que não gosta de estudar idiomas. Talvez essa motivação inicial, que é aparentemente intrínseca, tenha sido, na verdade, um impulso momentâneo, isolado, derivado da necessidade de se comunicar numa 
situação específica. Consequentemente, acreditamos não ter sido realmente produtora de valores centrais, que moveriam o participante a tendências mais desejáveis, por exemplo, a enxergar sentimentos com tonalidades mais positivas em sua experiência com o idioma. Quanto à aplicação, faz uso instrumental, para leitura de materiais de sua área de atuação. Como já dissemos, apesar de não ser a mais desejável de todas, admitimos a relevância de encontrar usos para novos conhecimentos, especialmente linguísticos.

- Sentimentos: Como dissemos, as tonalidades afetivas aqui são bastante desfavoráveis à construção de valores centrais, na medida em que o participante declara não gostar de estudar idiomas e se sentir "um caipira" quanto à sua competência oral, denotando um sentimento de não pertencimento, de afastamento do grupo no qual o conhecimento linguístico se insere. Além do mais, sua tentativa anterior de estudar línguas (alemão) foi motivada pelo fato de sua mãe e tia falarem tal língua fluentemente, e tratou-se de uma experiência informal, sem sistematização ("por conta”). Por um lado, a motivação novamente parece intrínseca, mas, em seguida, declara que gostaria de aprender "por causa delas", o que é uma evidência de origem extrínseca (a origem é o outro). Novamente, temos a sensação de que o participante fala de pertencimento. Aprender alemão "por causa delas", talvez para se aproximar, ter algo em comum com elas, mantê-las vivas em sua recordação, pessoas estimadas "que não estão mais aqui". Nesse contexto, o fato da tentativa ter sido informal (que poderia ter sido, em outros casos, um sinal de valorização) ao contrário, sugeriu energética fraca, pouca valorização: por não gostar de estudar línguas (mas buscando o pertencimento), o menos custoso seria fazê-lo "por conta", sem compromissos. Por fim, observamos um possível sentimento ideológico, ligado aos ideais coletivos: "quando sou corrigido me sinto normal, é importante".

- Valorizações: O participante prefere leitura a todas as outras habilidades. Como vimos, é uma atividade mais receptiva, em termos de interação. O pouco deslocamento em relação à sua zona de conforto denota valorizações periféricas. Há pouca energia disponível para suportar o contato com o outro. Além disso, não utiliza nenhum tipo de material de suporte para seu aprendizado, o que também mostra valorizações periféricas. Especialmente por se tratar de um curso 
intensivo, que requer bastante esforço dos alunos para evitar acúmulo de tarefas e de dúvidas. Entendemos, inclusive, que o acúmulo de tarefas pode ser motivo e baixas valorizações, lembrando que uma ação desgastante não é sinônimo de custosa.

- Metas: Quanto a mudanças, o entrevistado declara que adquirir conhecimento "é legal", no entanto, não deixa clara a percepção de mudanças pessoais, ou melhor, a percepção do processo de aprendizagem como agente de mudanças. O que mudou "um pouco" é de natureza profissional. Quanto a metas, não citou projeções futuras nem mostrou objetivos claro; ao contrário, revelou dúvidas inclusive quanto à sua capacidade de manter o conhecimento linguístico. Logo, constatamos pouca disponibilidade energética para a confecção de metas e, consequentemente, existência de valores periféricos.

- Relação entre as línguas: Faz relação de semelhança gramatical entre os idiomas: "Ajudou um pouquinho a relembrar a gramática do português; tem uma certa semelhança". Tais aproximações nos surpreenderam e indicam que é necessário reflexão por parte de nós, professores, sobre nossos métodos de ensino. A gramática do inglês é, na verdade, bastante diferente da gramática do português. Dizer que há semelhança entre elas revela uma análise muito superficial por parte dos alunos, apoiada em elementos comuns a todas as línguas (classes de palavras e flexões, por exemplo) e está longe da percepção dos mecanismos linguísticos. Algo para os professores pensarem.

- Considerações: Verificamos valorizações bastante periféricas, especialmente no que se refere a sentimentos e interação com o outro. Além disso, ao invés de objetivos claros quanto ao futuro, encontramos incertezas e dúvidas em relação à capacidade de manter o conhecimento linguístico. Para que haja construção de valores mais centrais e, consequentemente, garantia de que o processo de aprendizagem seja bem-sucedido e o conhecimento se mantenha, o participante precisa encontrar sentido no estudo do idioma, principalmente em relação a si mesmo. Se houve algum aprendizado, significa que ocorreu adaptação a uma nova condição, e que ele pode (e deve) se beneficiar disso. 


\subsection{Quarto Estudo de Caso: M9}

Trata-se de um contador, de 31 anos. De seu depoimento, destacamos as seguintes observações:

- Motivações: O participante manifestou "crença na universalidade" do idioma em ambas as oportunidades de resposta, porém, na primeira questão (motivação), destaca a predominância do profissional: "Atualmente estou estudando por causa do meu trabalho". Por essa razão, a resposta foi classificada como "motivação extrínseca - profissional". Quanto à segunda questão (importância), cita a grande necessidade de comunicação na atualidade, e reitera que o inglês "faz parte da ramificação de qualquer área". Foi classificada como “crença na universalidade" por ser um tanto vaga, difusa, não se referindo nem aos seus próprios interesses nem aos interesses profissionais. No que diz respeito à aplicação, faz uso comunicativo - que provoca maiores deslocamentos da zona de conforto. Dessa maneira, existe mais energética disponível para suportar e ser bem sucedido na interação.

- Sentimentos: O participante manifesta sentimentos, em sua maioria, com tonalidades positivas. Afirma gostar da língua e estar "apaixonado" poe ela. Menciona, por outro lado, certa ambivalência quanto à habilidade oral: apesar de sentir-se "realizado", luta contra a "questão de falar em inglês sem pensar em português". Essa recomendação faz parte do método da escola - encorajar os alunos a pensar em inglês. Sabemos que a tendência a fazer traduções mentais todo o tempo não é favorável à fluidez das ideias e, consequentemente, à fluência oral, no entanto, mais uma vez, lembramos que não é possível ignorar a presença da língua materna na vida de uma pessoa. O prejuízo está nas altas dosagens, nas altas frequências dessas traduções mentais. Nesse caso, tanto pode haver uma questão cognitiva, quanto pode ser indício de valorizações periféricas. Se o sujeito precisa submeter uma língua à outra, pode existir relação de soberania: entre elas apenas uma pode se destacar. Além disso, o entrevistado revelou tendências médias para o estudo de idiomas. Nunca estudou outras línguas, mas tem interesse por várias delas, e usa adjetivos para qualificá-las: "Gostaria de estudar italiano (charmoso, maravilhoso, gostoso de ouvir), 
espanhol, russo (interessante, muito difícil, diferente, desafiador)”.

- Valorizações: O entrevistado prefere falar, ou seja, existe disposição para deslocamentos em sua zona de conforto na interação com os sujeitos. Indica construção de valores centrais no processo de aprendizagem.

- Metas: Há um foco notadamente profissional nesse depoimento. Segundo o participante, as mudanças ocorreram majoritariamente no ambiente profissional, visto que a aquisição do conhecimento gerou a possibilidade de se enquadrar numa vaga de emprego. Novamente, uma tendência extrínseca, pois não cita nenhuma mudança nele mesmo. Porém, como ocorreu adaptação às necessidades, tais mudanças no ambiente devem se refletir, de alguma forma, nele mesmo. O participante apenas não deu um foco pessoal às mudanças, pois seu foco está nas relações profissionais. Prova de que há percepção de mudança intrínseca está no fato de expressar sonhos: "Se estivéssemos falando eu sonhos, eu projetava que seria um cidadão britânico", mas conclui seu depoimento sobre metas dizendo: “me vejo um profissional da área em que já atuo".

- Relação entre as línguas: Faz relação de aproximação gramatical, e os comentários do estudo de caso anterior são válidos aqui.

- Considerações: Partindo da crença na universalidade da língua, o participante definiu suas motivações e metas em função de suas necessidades fortemente relacionadas ao ambiente profissional, ou seja, a partir de tendências mais extrínsecas. Tais definições mostraram-se bastante favoráveis, na medida em que aproveitam e canalizam a energética a ser empregada de maneira adequada. Além disso, o entrevistado faz uso comunicativo da língua no trabalho e manifesta tendências desejáveis quanto a sentimentos e valorizações (saída de sua zona de conforto), ainda que haja ambivalências ligadas à competência oral. Acreditamos, portanto, que haja energética para construção de valores centrais quanto ao estudo do idioma. 


\section{Considerações Finais}

A presente dissertação teve como principal objetivo investigar as valorizações afetivas dos estudantes adultos em relação ao aprendizado da língua estrangeira sob a ótica piagetiana da construção do conhecimento e da afetividade, buscando entender a construção de tais valores a partir das motivações que levaram esses aprendizes a ter contato com o novo idioma. Dessa forma, procuramos contribuir com o trabalho dos profissionais da Psicologia, da Educação e também da Psicopedagogia.

Nossa hipótese inicial partiu do princípio de que o interesse, do ponto de vista afetivo, coordena-se num sistema de valores que, por sua vez, será construído pelo aprendiz no contato com a nova língua. Dessa forma, acreditamos que a qualidade do interesse - que é, em última análise, o valor - estaria diretamente ligada ao aumento ou à diminuição do fracasso e das frustrações do aprendiz de línguas e às suas projeções futuras.

A concepção de valor foi formulada por Piaget (1954) com base nas ideias de Pierre Janet e de Edouard Claparède, para quem o interesse (ligado à afetividade) desempenha um papel essencial no funcionamento intelectual. Piaget associou, então, o sistema de regulações (energética) proposto por Janet à ideia de interesse de Claparède, definindo valor como "aspecto qualitativo do interesse", "expansão da atividade do eu na conquista do universo", "intercâmbio afetivo com o exterior". Ligando valores a interesses - na medida em que interesse é o combustível para a construção de conhecimento e o valor é seu aspecto qualitativo - podemos dizer que o interesse tem, portanto, função regulatória, aumentando ou diminuindo a quantidade de energia empregada na interação com o objeto de conhecimento. Como alguns objetos são mais interessantes que outros, o aprendiz tende a coordená-los qualitativamente, num sistema de valores pessoais, no qual alguns valores assumem posições mais centrais que outros.

No intuito de complementar a investigação teórica sobre os interesses, abordamos, também, o tema da motivação. Para Ryan e Deci (2000) a motivação funciona como um regulador do comportamento, na medida em que os comportamentos diferem principalmente no quanto sua regulação provém de uma escolha livre ou da pressão de alguma força externa ou intrapsíquica. O processo regulatório subjacente é, portanto, a escolha.

Além disso, ainda quanto ao embasamento teórico, buscamos relações entre a língua inglesa e seu papel na modernidade, além de discutir o processo de ensino e aprendizagem dessa língua em escolas de idiomas sob diversos aspectos, desde a formação do professor até as principais dificuldades do aluno. 
Apoiados na teoria piagetiana da construção da inteligência e da afetividade, apresentamos, na segunda parte desse trabalho uma pesquisa feita com alunos adultos, nosso público majoritário em escolas de idiomas, no intuito de verificar como se constroem valores fortes o suficiente para que o sujeito consiga ter êxito em seu processo de aquisição do conhecimento linguístico.

Procuramos mostrar como os quatro eixos de nosso trabalho - motivações, sentimentos, valorizações e metas - combinam-se para formar valores centrais para os sujeitos.

Quanto aos resultados, podemos destacar alguns dados em relação à dimensão afetiva. Pudemos verificar, por exemplo, que $25 \%$ dos entrevistados declararam sentimentos com tonalidades negativas no contato com o novo idioma. Na tentativa de evitar o fracasso, o sujeito tende a se isolar, desenvolvendo bloqueios. Nesses casos, os sentimentos não propiciariam a construção de valores centrais quanto ao idioma. Verificamos também, que as mulheres manifestaram mais sentimentos com tonalidades positivas do que os homens, exceto no que se refere especificamente à habilidade oral, quando elas declararam mais sentimentos negativos que os homens.

Ressaltamos, ainda, a relação entre motivações e metas. Quando perguntados sobre motivações iniciais, 52,5\% dos participantes declararam motivações profissionais. Quando perguntados sobre metas, apenas $35 \%$ dos participantes declararam metas profissionais. Esse resultado nos surpreendeu pois esperávamos que as metas refletiriam basicamente as motivações iniciais e, portanto, as porcentagens seriam mais próximas. É um indício muito favorável de que os adultos descobrem outros usos e aplicações do idioma ao longo do processo de aprendizagem, e estes novos interesses incorporam-se gradativamente ao sistema de interesses do sujeito, em posições privilegiadas. Comprovamos, dessa maneira, a importância da perceber o processo de aprendizagem como agente modificador na vida dos estudantes.

Cientes de que ainda há muito para se estudar, nosso intuito foi o de ofertar, no presente ensaio de reflexão teórica, um panorama de questões de cunho tanto pedagógico como psicológico, de acordo com nossas próprias inquietações. 


\section{Referências}

Aguiar, R. de. (2009). O discurso sobre a obrigação em aprender uma língua estrangeira. Universidade Federal do Paraná.

Andreozzi, M. L. (2007). Piaget e a intervenção psicopedagógica. São Paulo: Olho d'Água.

Archibald, J., Roy, S., Harmel S., Jesney K., Dewey E., Moisik S. \&Lessard P. (2006). A Review of the Literature on Second Language Learning. University of Calgary. Language Research Centre.

Baptista, L.M.T.R. (2000). Teorias linguísticas e aquisição e aprendizagem de línguas. Todas as letras, (2), 77-85.

Bee, H. (1997). O Ciclo Vital. Porto alegre: Artmed.

Cardoso, L.R \& Bzuneck, J.A (2004). Motivação no ensino superior: metas de realização e estratégias de aprendizagem. Psicologia Escolar e Educacional, 8(2), 145-155.

Callegari, M.O.V. (2006). Reflexões sobre o modelo de aquisição de segundas línguas de Stephen Krashen - uma ponte entre a teoria e a prática em sala de aula. Trab. Ling. Aplic., 45(1), 87-101.

Coracini, M. J.(2003). O discurso publicitário sobre as escolas de língua e a constituição da identidade. Letras \& Letras, (1), 53-74.

Dardano, M. e Trifone, P. (1995) Grammatica Italiana com nozione de linguistica. Bolonha: Ed. Zanichelli, 3. ed.

De Mauro, T. (1991). Storia linguistica dell'ltalia unita. Bari: Editori Laterza

Deci, E. L. (1992). On the nature and functions of motivation theories. Psychological Science, $3(3)$.

Ellis, R. (1985). Theories of second language acquisition. In: Understanding Second Language Acquisition. Oxford: Oxford University Press

Ferrari, R.A., Witter, G.P. (2011). Motivação na aprendizagem da língua inglesa. Boletim Academia Paulista de Psicologia, 31(80), 121-135.

Flory, E.V. (2008). Influências do bilinguismo precoce sobre o desenvolvimento infantil: uma leitura a partir da teoria da equilibração de Jean Piaget. Tese de doutorado - Instituto de Psicologia da Universidade de São Paulo

Foucault, M. (2008). A arqueologia do saber. Rio de Janeiro: Forense Universitária, 7. edição. Freitas, L. (2003). A moral na obra de Jean Piaget: um projeto inacabado.São Paulo: Cortez Freitas, M.A., Belincanta, C.I., \& Corrêa, H.C.M.O. (2002). Professores de língua inglesa em formação: mudando crenças e atitudes. Trab. Ling. Aplic., (39) 47-67. 
Gagné, M. \& Deci, E.L. (2005). Self-determination theory and work motivation. Journal of Organizational Behavior 26, 331-362.

Gimenez, T.N. \& Cristovão, V.L.L. (2004). Derrubando paredes e construindo pontes: formação de professores de língua inglesa na atualidade. Rev. Brasileira de Lingüística Aplicada, 4(2).

Guimarães, S. E. R., \& Boruchovitch, E. (2004). O Estilo Motivacional do Professor e a Motivação Intrínseca dos Estudantes: Uma Perspectiva da Teoria da Autodeterminação. Psicologia: Reflexão e Crítica, 17(2), 143-150.

Haddad, S. (coord.)(2000). O Estado da Arte ds pesquisas em educação de jovens e adultos no Brasil: a produção discente da pós-graduação em educação no período 1986-1998. São Paulo: Ação Educativa.

Ianni, O. (1994). Globalização: Novo paradigma das ciências sociais. Estudos avançados , 8(21),147-163.

Jordão, C. M. (2004). A língua inglesa como 'commodity': direito ou obrigação de todos. VIII Congresso Luso-Brasileiro de Ciências Sociais.

Knowles, M. S. (1970). Modern Practice of Adult Education: From Pedagogy to Andragogy. Cambridge.

Krashen. S.D. (1981). Second Language Acquisition and Second Language Learning. First internet edition December 2002.

Lages, S. K. (2002). Walter Benjamin: Tradução e Melancolia. São Paulo: EDUSP.

Leite, C.M.B. (2010). Atitudes linguísticas e teoria da acomodação: inter-relação entre sociolinguística e psicologia social. In: Seminário do GEL, 58.

Leme, M. I. da S. (2011). As especificidades humanas e a aprendizagem: relações entre cognição, afeto e cultura. Psicologia USP, 22(4), 703-723.

Lovato, C.S \& Tamanini-Adames, F.A. (s.d.) Teorias, estágios e contextos de aprendizagem de segunda língua. Disponível em http://scholar.google.com.brMarzari, G.Q., Santos, C.G. \& Zimmer, M.C. (2012). Estratégias de preservação cognitiva em indivíduos idosos: o papel da aprendizagem de uma língua estrangeira, Letrônica 5(3), 103-124.

Montero, P. (1997). Globalização, identidade e diferença. Novos Estudos CEBRAP, (49), 4764.

Nejadansari, D. \& Nasrollahzadeh, J. (2011). Effects of Age on Second Language Acquisition. Studies in Literature and Language, 3(3), 19-24.

Nobre, A.P.M.C. \& Hodges, L.V.S.D. (2010) A relação bilinguismo-cognição no processo de alfabetização e letramento. Ciências \& Cognição, 15(3): 180-191. 
Nosarti, C., Mechelli, A., Green, D.W. \& Price, C. (2010). The Impact of Second Language Learning on Semantic and Nonsemantic First Language Reading. Cerebral Cortex, 20, 315327.

Oliveira, M. K. (1999). Jovens e adultos como sujeitos de conhecimento e aprendizagem. In: Fávero, O. \& Ireland, D.T. (orgs.). Educação como exercício de diversidade. Brasília: UNESCO, MEC, ANPEd, 2005.

Ortiz, R. (2008). A diversidade dos sotaques (o inglês e as ciências sociais). São Paulo: Brasiliense.

Perius, O. (2011). A filosofia da linguagem em Walter Benjamin. Semana Acadêmica do PPG em Filosofia da PUCRS, VII Edição.

Piaget, J. (1975). Inconsciente afectivo e inconsciente cognoscitivo. In: Problemas de Psicología Genética. Barcelona: Ariel.

Piaget, J. (1954). Les relations entre l'affectivité et l'intelligence dans le dévéloppement de l'enfant. Bulletin de Psychologie, 7, 69-71; 143-150; 522-523.

Piaget, J. (1994). Las relaciones entre la inteligencia y la afectividad en el desarrollo del niño. In Delahanty, G. \& Perrés, J. (Eds.) Piaget y el psicoanálisis (pp. 181-289). Universidad Autónoma Metropolitana: Xochimilco.

Piaget, J. (1974). O nascimento da inteligência na criança. Rio de Janeiro: Zahar.

Piaget, J. (1926). A representação do mundo na criança. São Paulo: Record

Piaget, J. (1964/2007). Seis estudos de Psicologia. Rio de Janeiro: Forense Universitária.

Piaget, J. e Inhelder, B. (1974). A Psicologia da Criança. São Paulo: Difel.

Revuz, C. (1998). A língua estrangeira entre o desejo de um outro lugar e o risco do exílio. In: Signorini, I.(org.). (1998). Lingua(gem) e identidade: elementos pra uma discussão no campo aplicado. Campinas, SP: Mercados das letras.

Ryan, R. M. \& Deci, E. L. (2000). Intrinsic and Extrinsic Motivations: Classic Definitions and New Directions. Contemporary Educational Psychology, 25, 54-67.

Santana, G.M. de (2008). A dimensão afetiva no processo de ensino-aprendizagem de línguas estrangeiras. Anuario brasileño de estudios hispánicos XVIII, 106-112.

Santos, C. \& Kader, C.C.C. (2012). Os modelos de leitura bottom-up , top-down e aproximação interativa. Revista de Ciências Humanas, 10(15), p-73

Santos, E.S.S. (2011). O ensino da língua inglesa no Brasil. BABEL: Revista Eletrônica de Linguas e Literaturas Estrangeiras, (1), dezembro.

Souza, M.T.C.C. (2001). As relações entre afetividade e inteligência no deselvolvimento psicológico. Psicologia: Teoria e Pesquisa, 27, 249-254. 
Stevenson, R.L. (1997). O médico e o monstro. São Paulo: FTD

Verne, J. (s.d.). Vinte mil léguas submarinas. São Paulo: Círculo do Livro.

Vogt, M.S.L., Alves E.D. (2005). Revisão teórica sobre a educação de adultos para uma aproximação com a andragogia. Revista Educação, 30(2).

Welp, A.K.S.(2009). A ansiedade e o aprendizado de língua estrangeira. Letras de Hoje, 44 (3), 70-77.

Zenorini, R.P.C., Santos, A.A.A., \& Monteiro R.M. (2011). Motivação para aprender: relação com o desempenho de estudantes. Paidéia, 21(49), 157-164. 
ANEXOS 


\title{
TERMO DE CONSENTIMENTO LIVRE E ESCLARECIDO
}

\author{
Título do projeto de pesquisa: Linguagem e identidade: conflitos entre língua materna e \\ língua estrangeira.
}

Prezado(a) Senhor(a), você está sendo convidado(a) a participar de uma pesquisa que estudará os elementos envolvidos na aprendizagem de uma língua estrangeira, do ponto de vista dos estudantes. Seu objetivo é contribuir para aumentar nosso entendimento sobre como adultos aprendem uma língua estrangeira.

A pesquisa será conduzida na própria escola de línguas onde você estuda, no horário que combinarmos. Sua colaboração se fará de forma anônima, por meio de entrevista a ser gravada, com duração aproximada de uma hora. Esta será conduzida por mim, Joseilde Maria Teles, estudante/pesquisadora, matriculada no mestrado de um programa de pós-graduação do Instituto de Psicologia da Universidade de São Paulo - IPUSP, sob a orientação da Professora Dra. Maria Thereza Costa Coelho de Souza. O acesso e a análise dos dados coletados se farão apenas pela pesquisadora e por sua orientadora.

Caso você experimente algum constrangimento ou desconforto durante a realização da entrevista, esta será interrompida, embora sua participação na pesquisa não ofereça riscos para você. Porém, indiretamente, você e a escola poderão ser beneficiados pelos resultados gerais da pesquisa, pelo conhecimento que poderemos elaborar, os quais poderão se reverter em melhor compreensão do processo educativo e seu aperfeiçoamento.

Vale ressaltar que a sua participação é voluntária e sigilosa, pois você não será identificado(a) quando o material de sua entrevista for utilizado, seja para propósitos de publicação científica ou educativa. Além disso, as informações coletadas serão utilizadas exclusivamente para fins de pesquisa e não terão implicações para sua vida acadêmica.

$\mathrm{Eu}$ declaro, por meio deste termo, que concordei em ser entrevistado(a) e participar da pesquisa intitulada Linguagem e identidade: conflitos entre língua materna e língua estrangeira, e que poderei contatar as pesquisadoras a qualquer momento que julgar necessário através do e-mail mailto: josie.teles@usp.br, ou para dúvidas sobre ética em pesquisa, com o Comitê de Ética em Pesquisa com Seres Humanos do IPUSP: Av. Professor Mello Moraes, 1721 - Bloco G, $2^{\circ}$ andar, sala 27 - CEP 05508-030 - Cidade Universitária São Paulo/SP - E-mail: mailto:ceph.ip@usp.br - Telefone: (11) 3091-4182. Afirmo que aceitei participar por minha própria vontade, sem receber qualquer incentivo financeiro ou ter qualquer ônus e com a finalidade exclusiva de colaborar para o sucesso da pesquisa. Declaro que recebi respostas para todas as minhas dúvidas. Confirmo também que recebi uma cópia deste Termo de Consentimento Livre e Esclarecido. Compreendo que sou livre para retirar minha autorização para a participação no estudo em qualquer momento, sem perda de benefícios ou de sofrer qualquer outra penalidade.

São Paulo, de de

Assinatura do(a) participante:

Assinatura da pesquisadora: 


\begin{tabular}{|c|c|c|c|c|c|}
\hline & 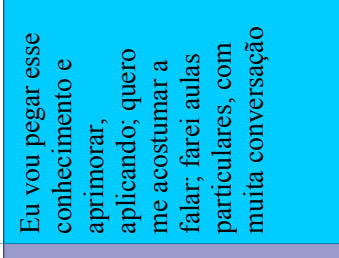 & 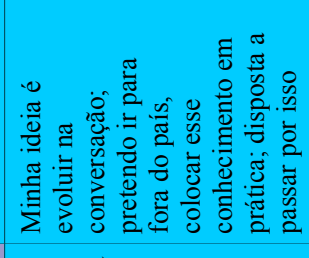 & 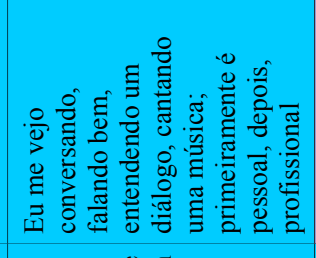 & 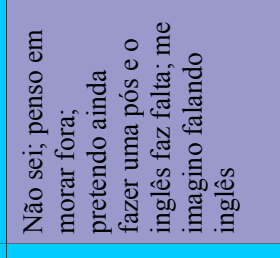 & 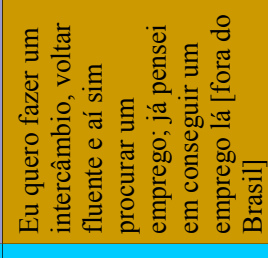 \\
\hline & 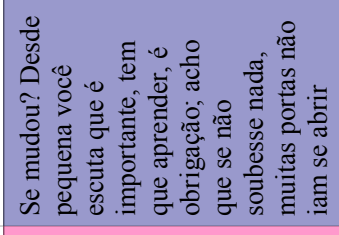 & 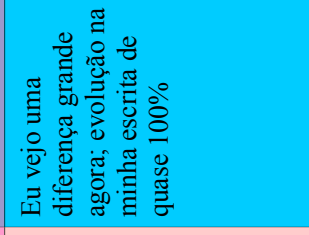 & 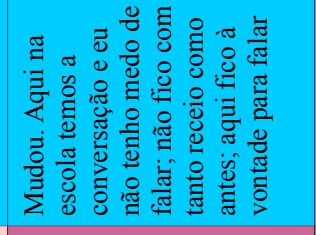 & 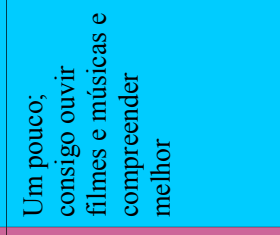 & 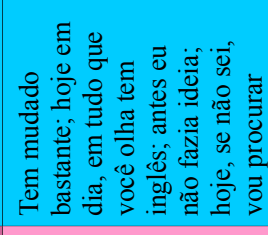 \\
\hline & 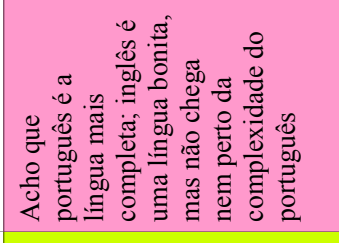 & 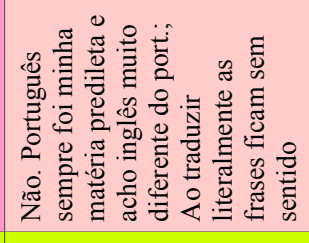 & 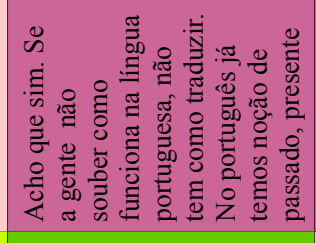 & 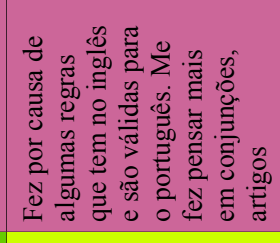 & 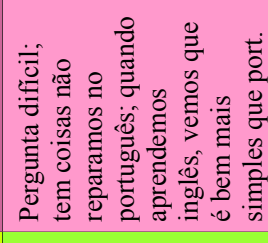 \\
\hline & 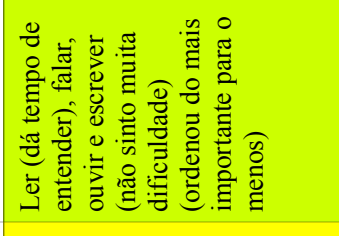 & 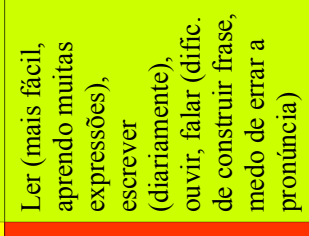 & 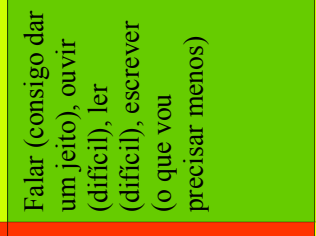 & 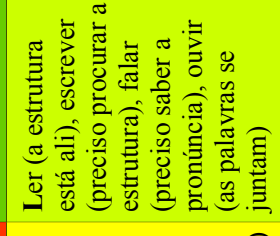 & 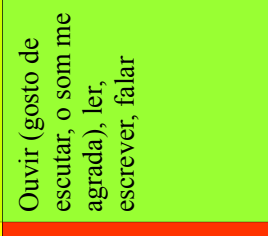 \\
\hline & 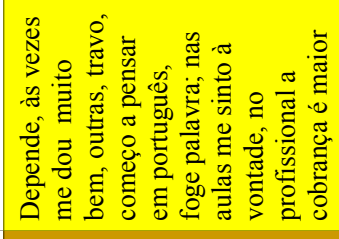 & 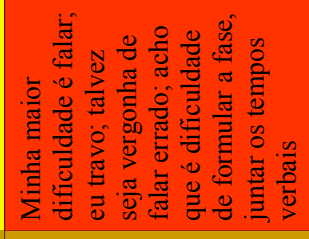 & 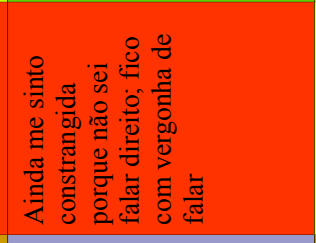 & 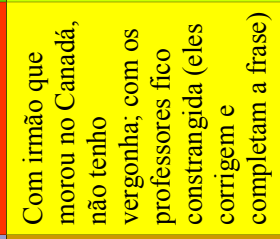 & 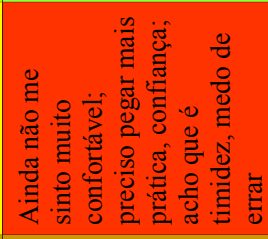 \\
\hline & 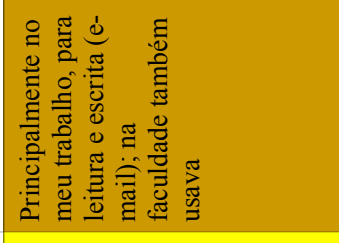 & 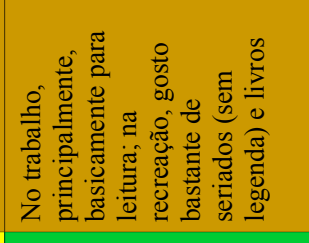 & 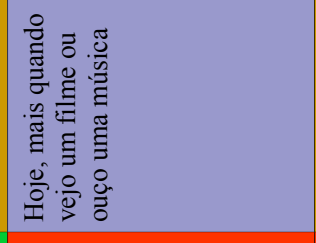 & 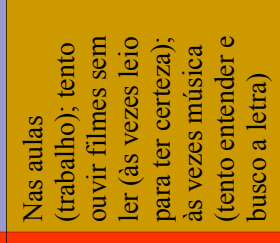 & 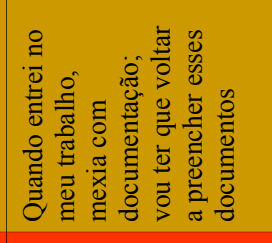 \\
\hline 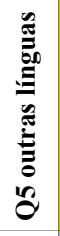 & 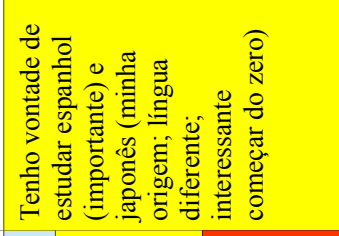 & 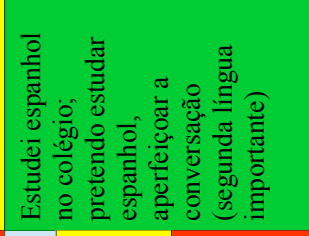 & 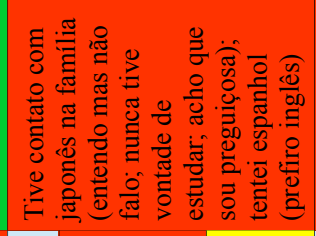 & 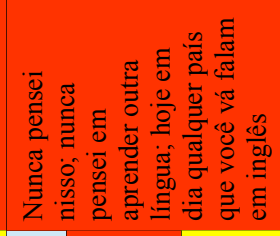 & 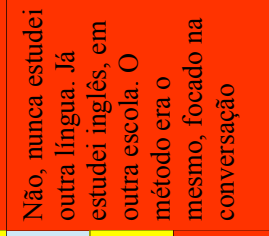 \\
\hline 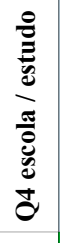 & 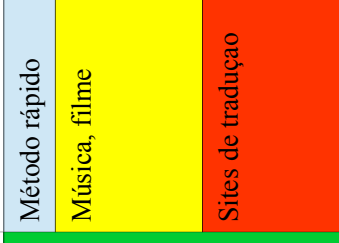 & 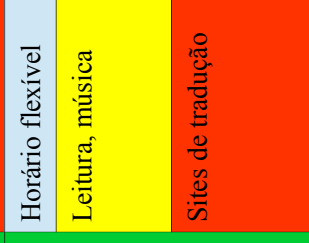 & 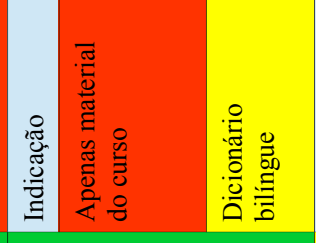 & 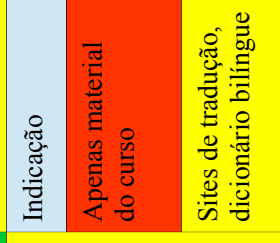 & 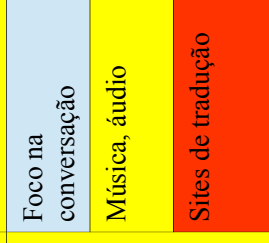 \\
\hline & 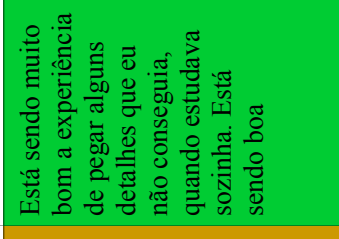 & 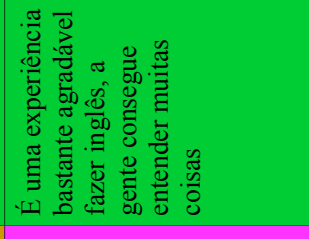 & 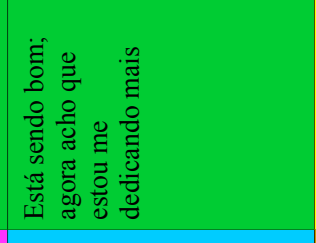 & 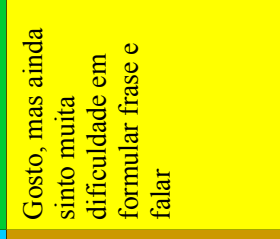 & 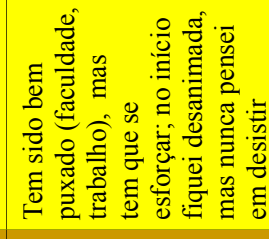 \\
\hline & 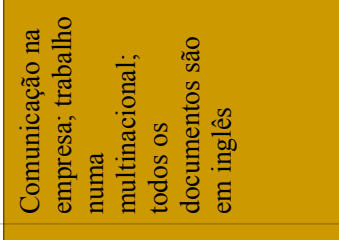 & 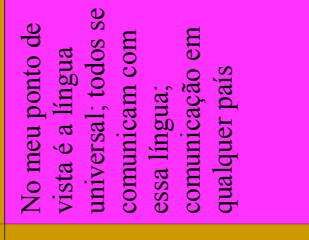 & 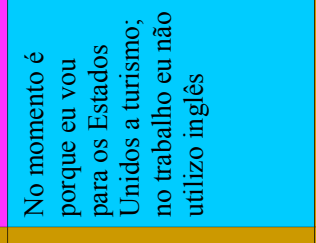 & 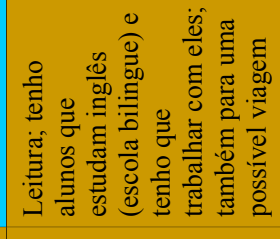 & 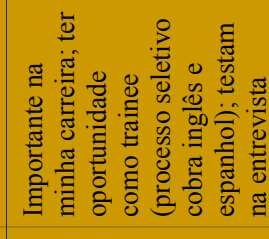 \\
\hline & 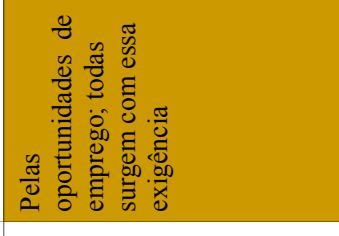 & 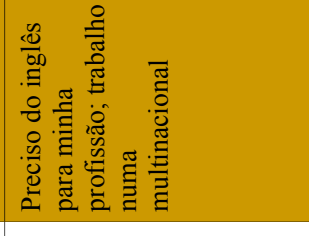 & 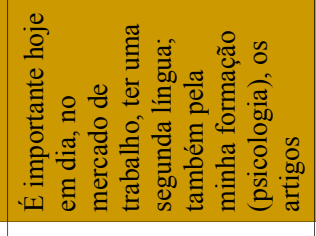 & 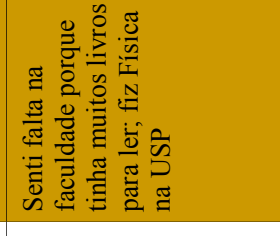 & 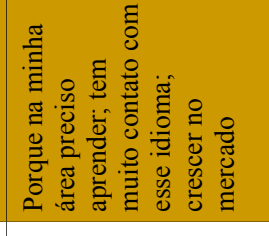 \\
\hline & $\bar{I}$ & $\widetilde{\Sigma}$ & I & I & 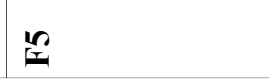 \\
\hline
\end{tabular}




\begin{tabular}{|c|c|c|c|c|c|}
\hline & 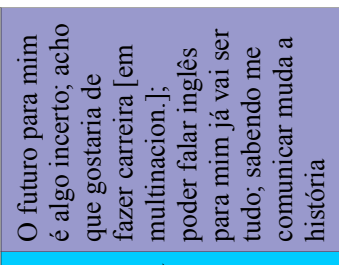 & 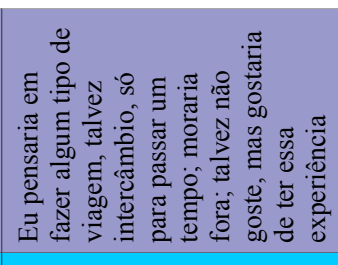 & 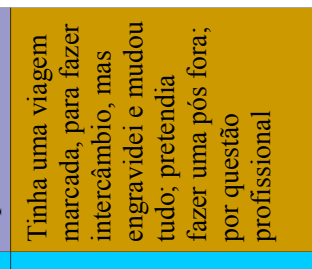 & 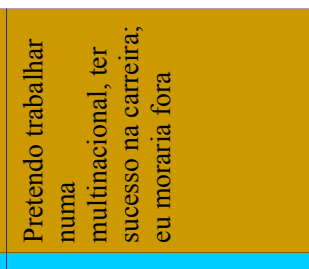 & 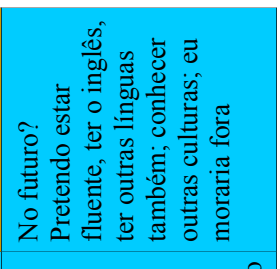 \\
\hline & 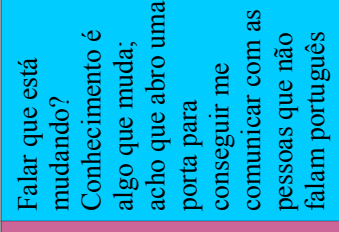 & 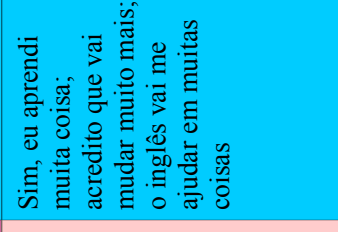 & 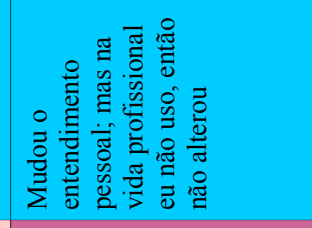 & 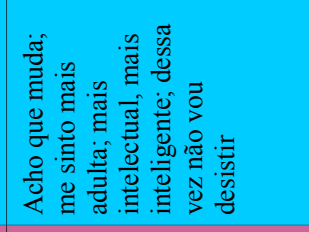 & 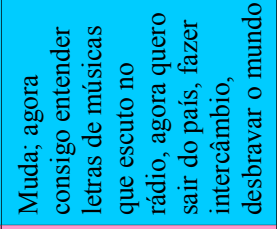 \\
\hline & 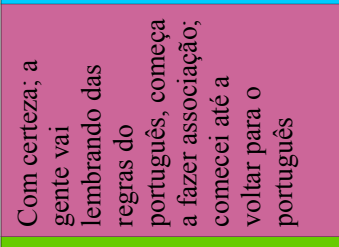 & 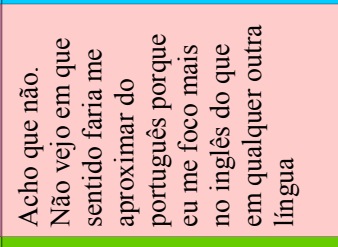 & 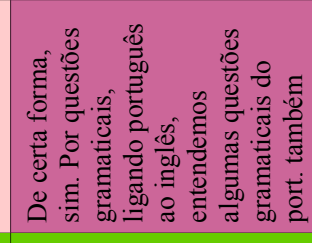 & 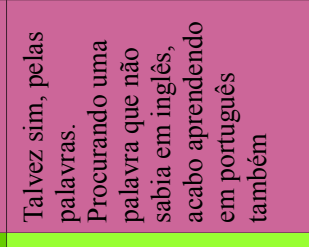 & 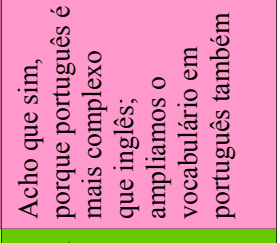 \\
\hline & 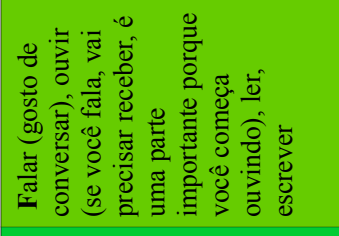 & 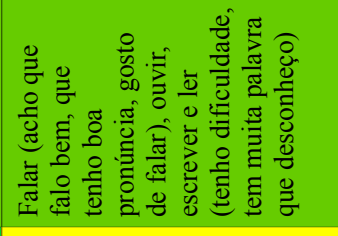 & 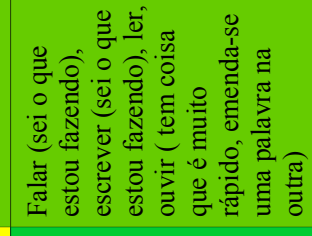 & 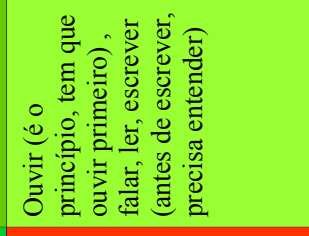 & 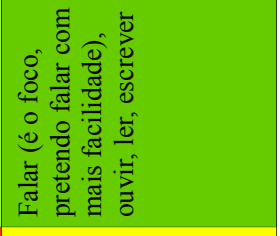 \\
\hline & 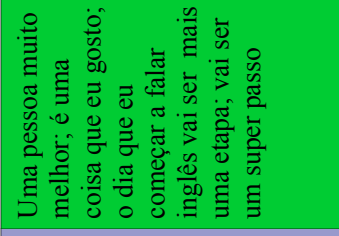 & 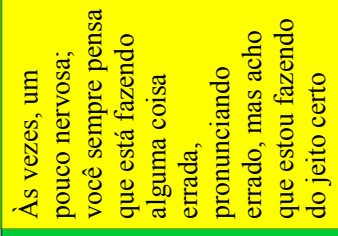 & 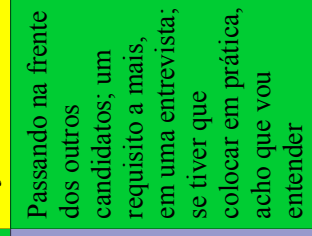 & 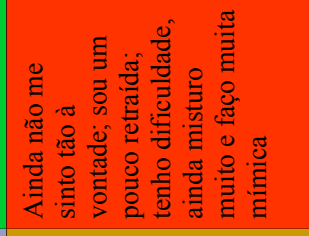 & 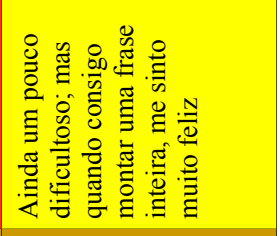 \\
\hline & 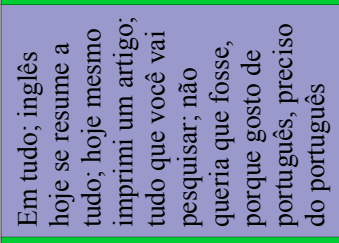 & 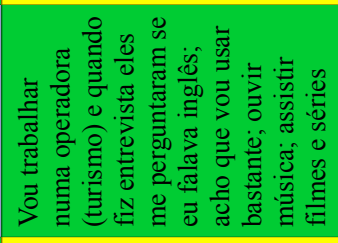 & 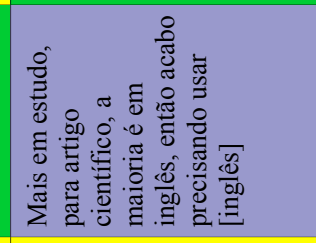 & 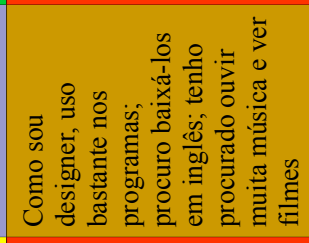 & 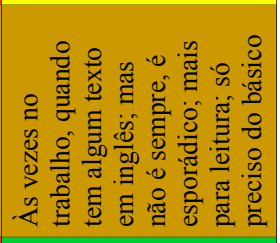 \\
\hline & 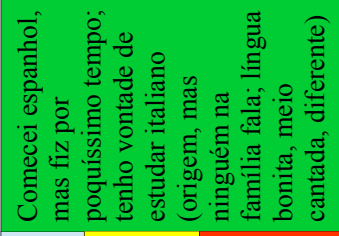 & 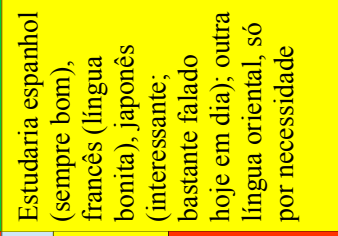 & 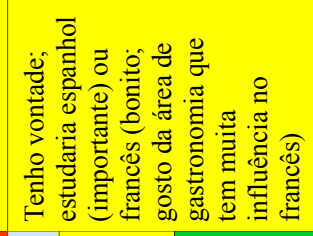 & 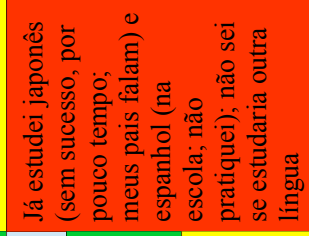 & 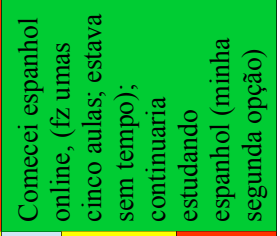 \\
\hline 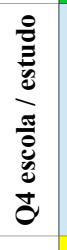 & 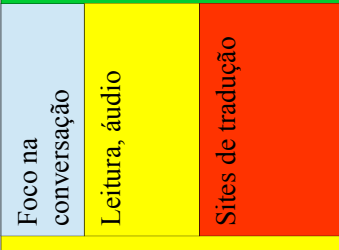 & 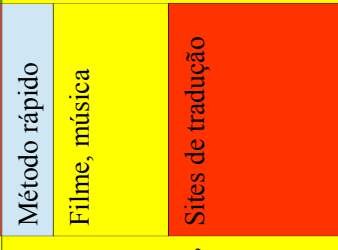 & 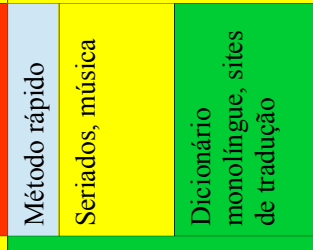 & 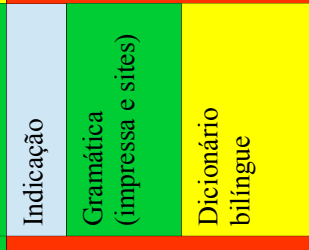 & 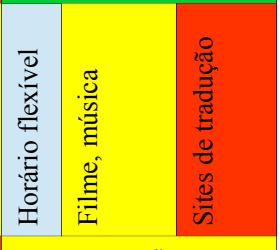 \\
\hline & 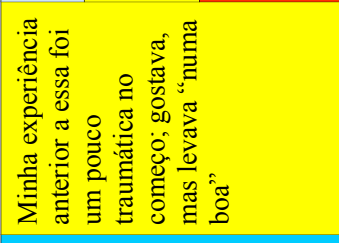 & 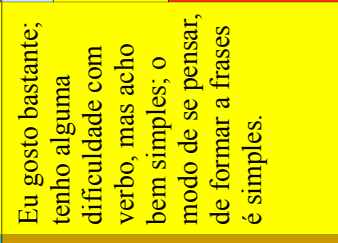 & 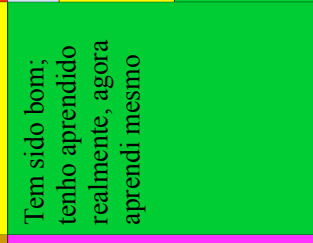 & 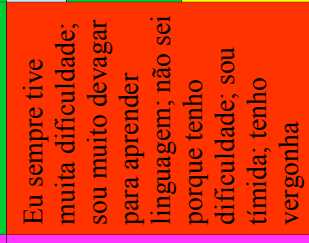 & 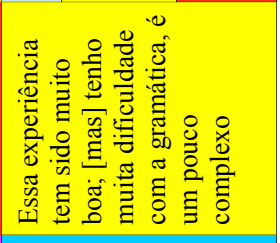 \\
\hline & 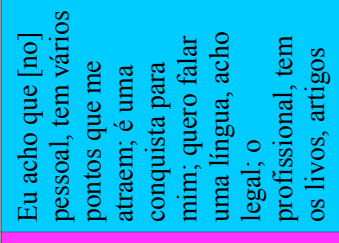 & 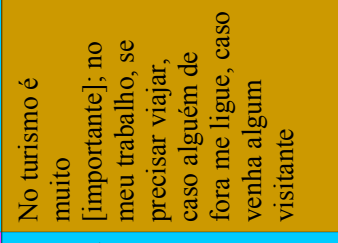 & 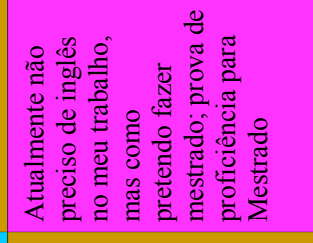 & 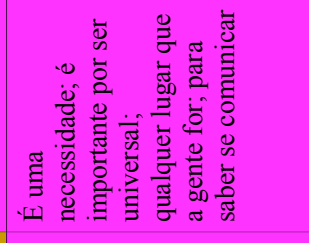 & 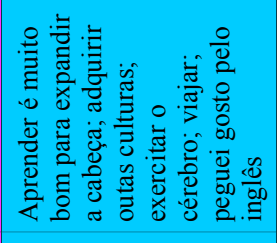 \\
\hline סृ & 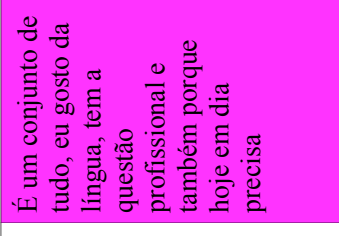 & 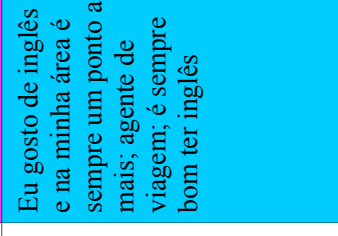 & 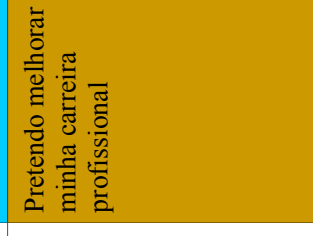 & 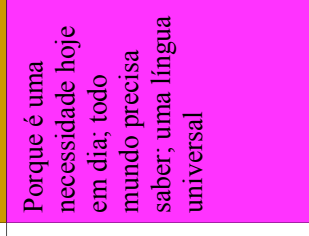 & 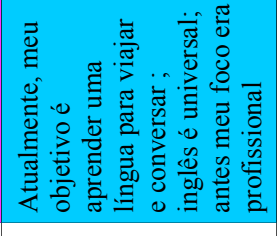 \\
\hline & t) & I & $\infty$ & 2ิ & $\stackrel{\theta}{x}$ \\
\hline
\end{tabular}




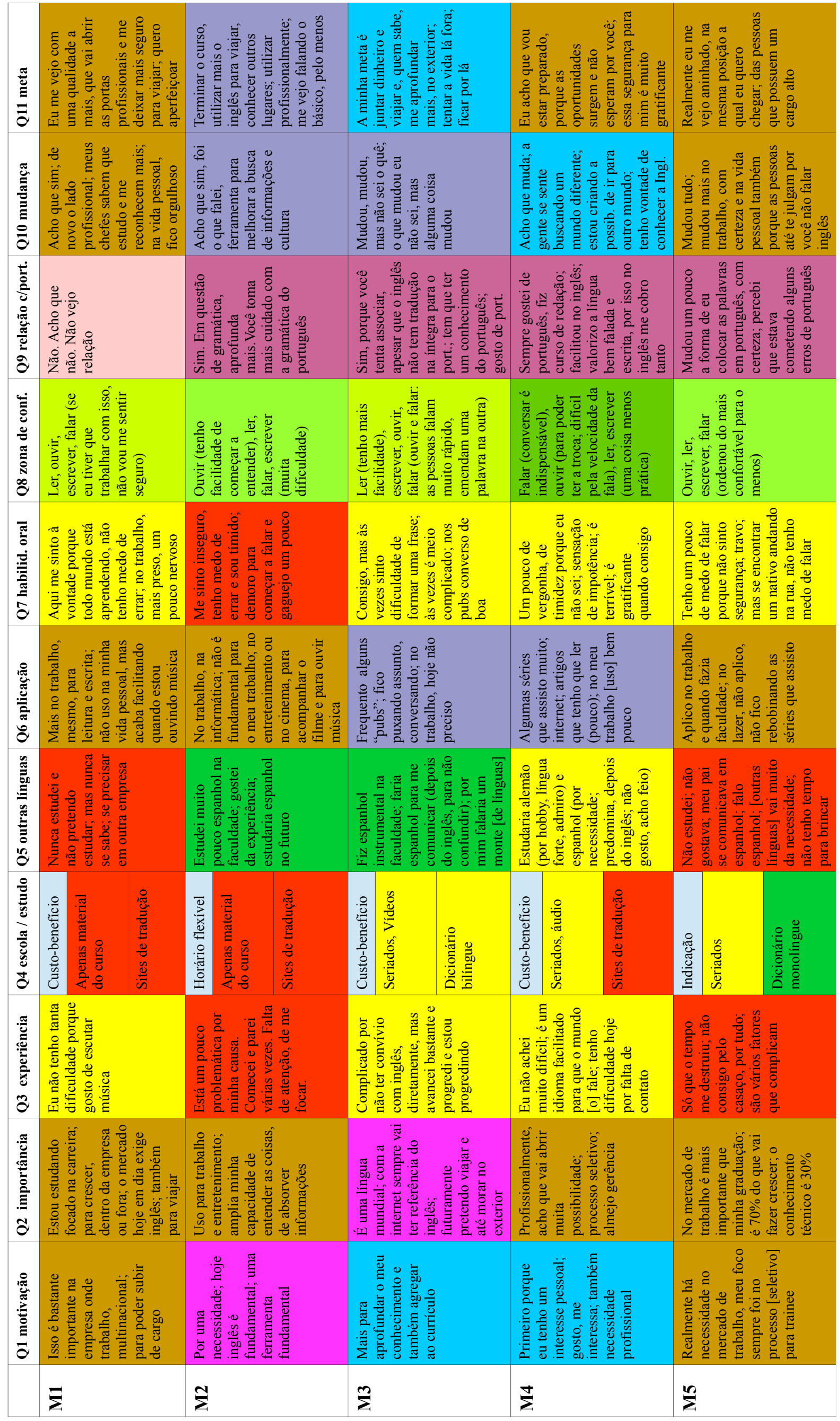




\begin{tabular}{|c|c|c|c|c|c|}
\hline & 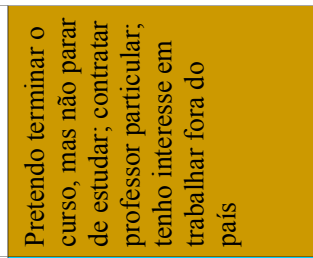 & 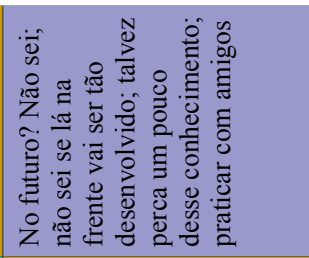 & 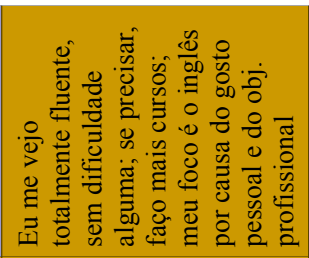 & 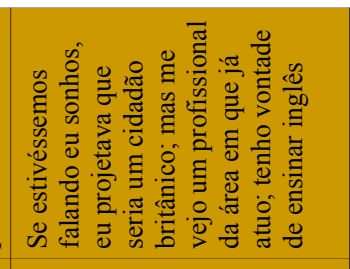 & 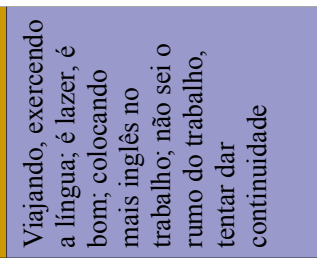 \\
\hline & 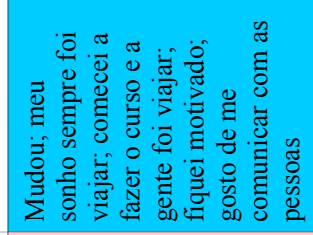 & 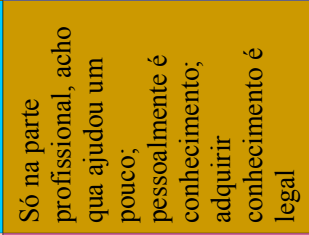 & 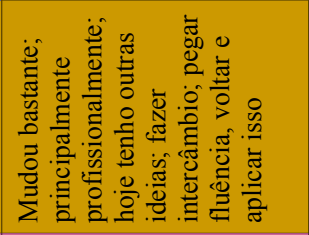 & 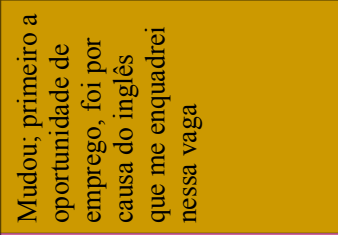 & 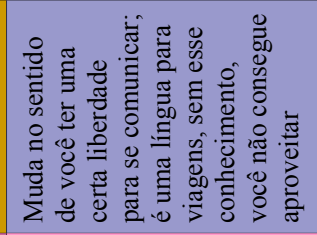 \\
\hline & 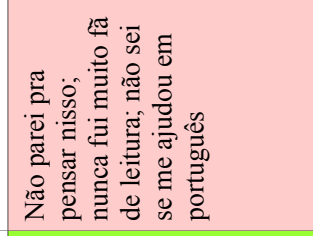 & 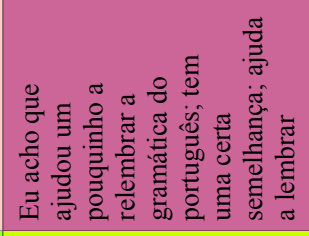 & 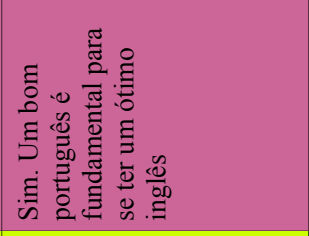 & 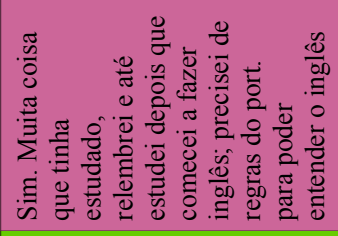 & 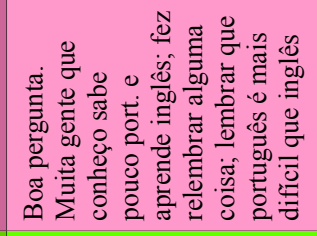 \\
\hline & 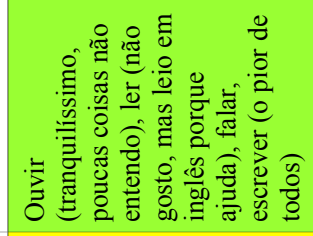 & 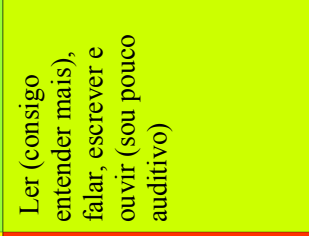 & 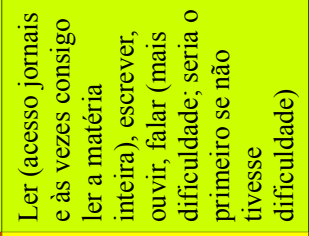 & 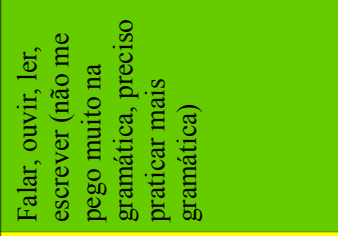 & 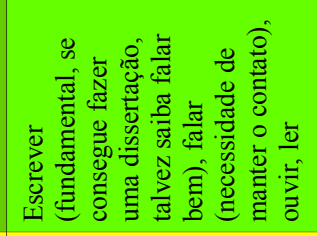 \\
\hline & 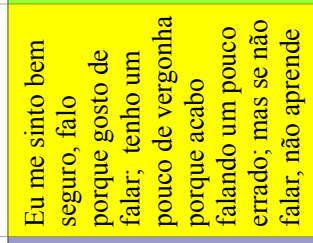 & 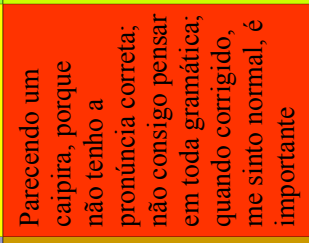 & 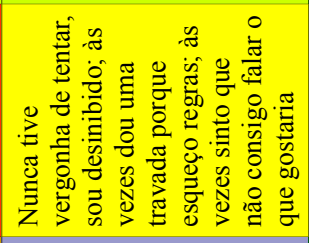 & 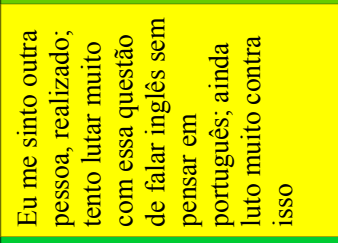 & 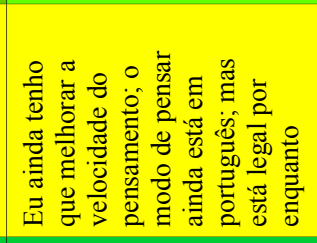 \\
\hline & 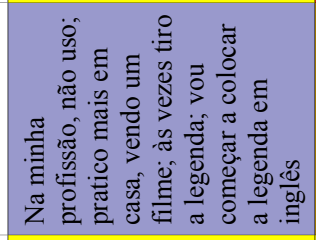 & 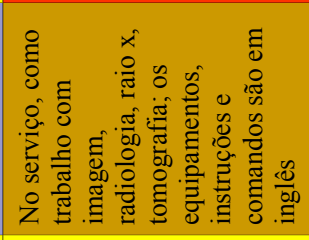 & 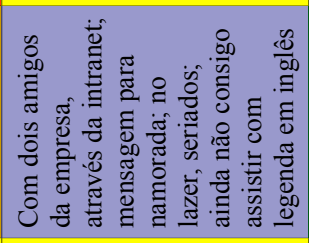 & 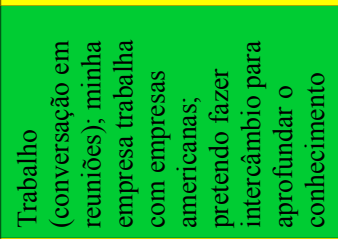 & 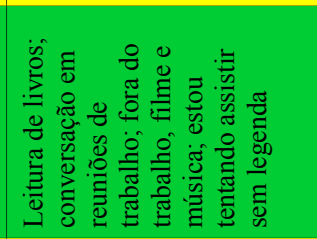 \\
\hline & 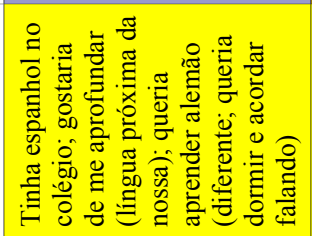 & 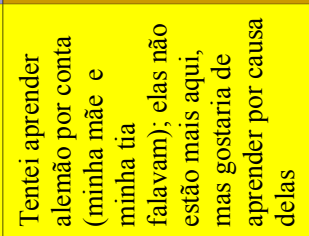 & 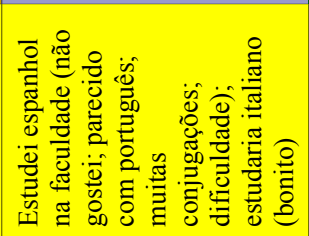 & 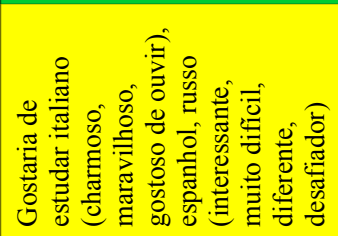 & 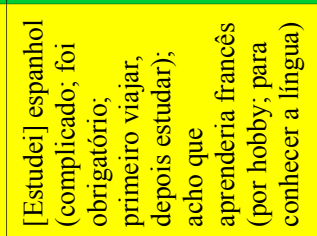 \\
\hline 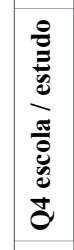 & 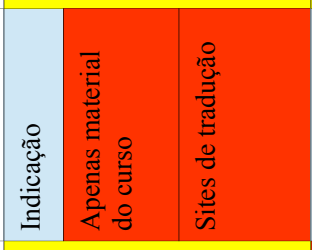 & 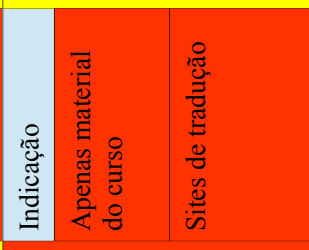 & 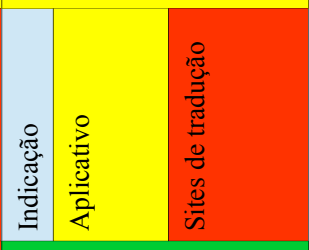 & 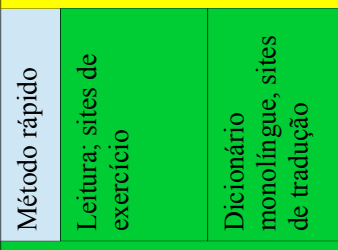 & 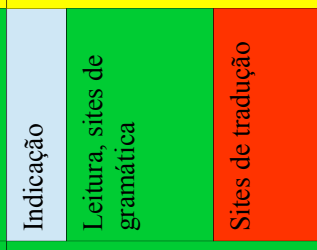 \\
\hline & 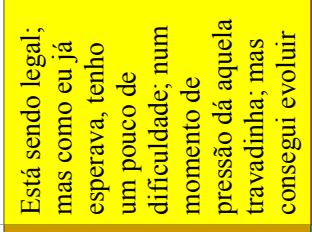 & 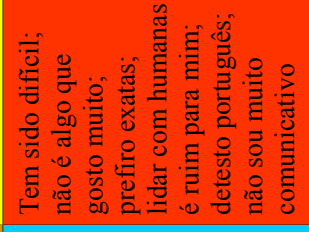 & 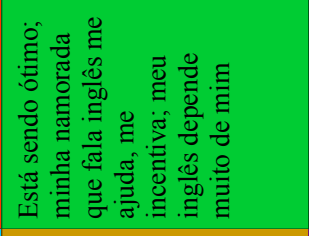 & 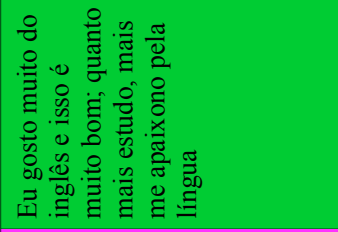 & 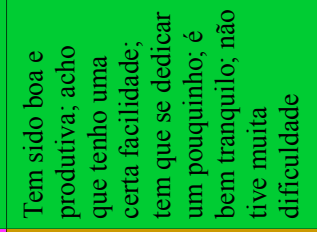 \\
\hline 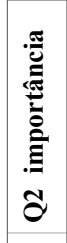 & 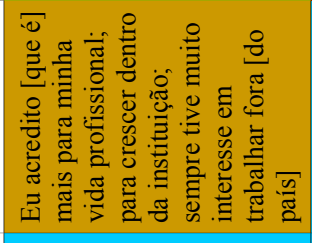 & 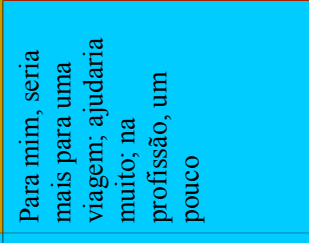 & 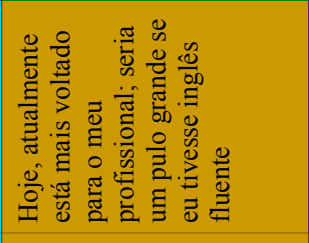 & 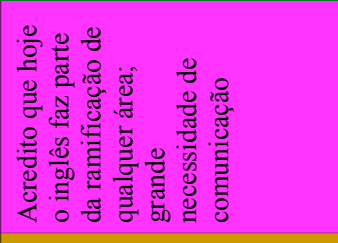 & 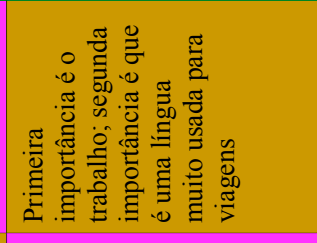 \\
\hline & 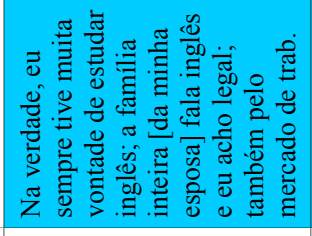 & 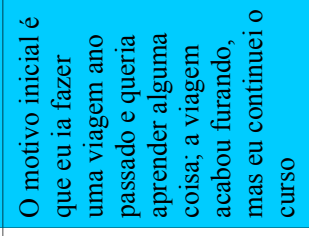 & 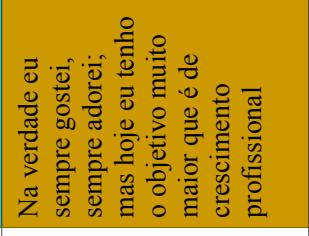 & 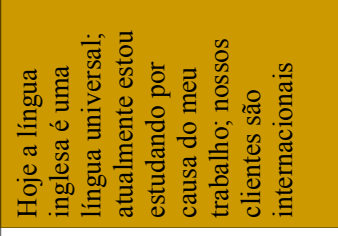 & 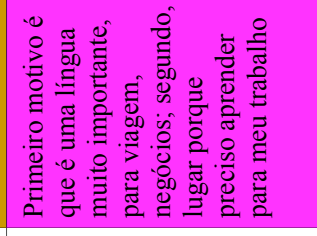 \\
\hline & $\sum^{\infty}$ & $\hat{\Sigma}$ & $\sum^{\infty}$ & $\stackrel{\partial}{\Sigma}$ & $\stackrel{\ominus}{\Sigma}$ \\
\hline
\end{tabular}




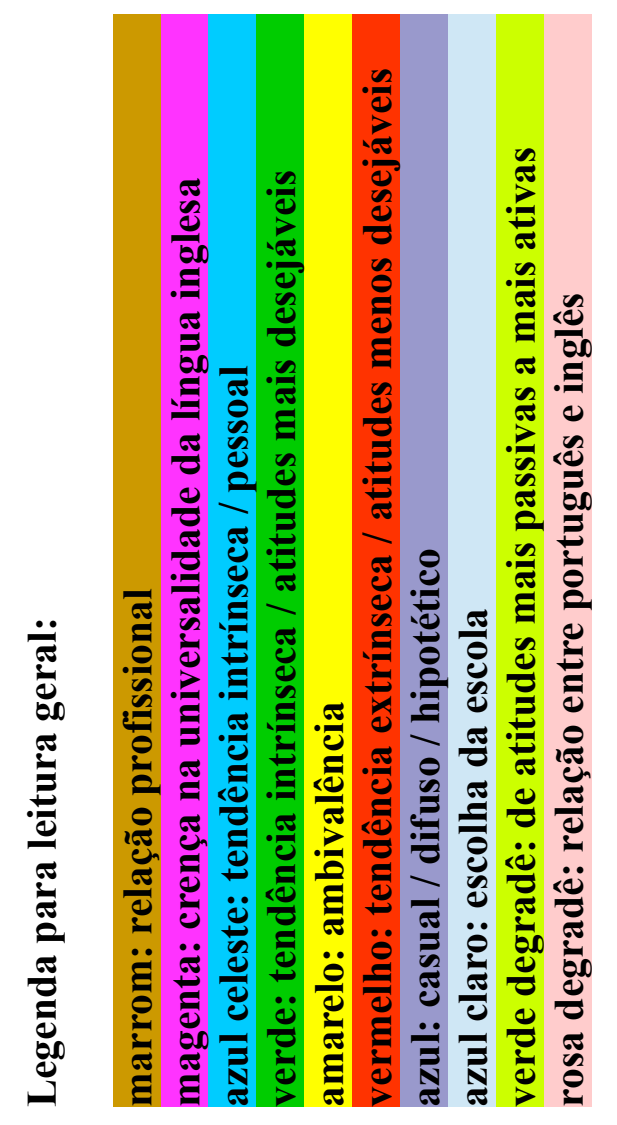

